\title{
POTENCIALIDADE DE CRUZAMENTOS ÓCTUPLOS DE SOJA COM ÊNFASE NA PRODUTIVIDADE DE GRÃOS
}

\author{
ÂNGELA CELIS DE ALMEIDA LOPES \\ Engenheira Agrônoma
}

Orientador: Prof. Dr. NATAL ANTONIO VELLO

Dissertação apresentada à Escola Superior de Agricultura "Luiz de Queiroz", da Universidade de São Paulo, para obtenção do título de Mestre em Agronomia, Área de Concentração: Genética e Melhoramento de Plantas.

PIRACICABA

Estado de São Paulo - Brasil

Novembro - 1996 
Dados Internacionais de Catalogação na Publicaçāo (CIP) DIVISÃo DE BIBLIOTECA E DOCUMENTAÇÃO - Campus "Luiz de Queiroz"/USP

Lopes, Ângela Celis de Almeida

Potencialidade de cruzamentos óctuplos de soja com ênfase na produtividade de grāos / Ângela Celis de Almeida Lopes. - - Piracicaba, 1996.

102 p. : il.

Dissertação (mestrado) - Escola Superior de Agricultura Luiz de Queiroz, 1997.

Bibliografia.

1. Cruzamento 2. Produtividade 3. Seleção recorrente 4. Soja (grão) I. Titulo

CDD 633.34 
POTENCIALIDADE DE CRUZAMENTOS ÓCTUPLOS DE SOJA COM ÊNFASE NA PRODUTIVIDADE DE GRÃOS

ÂNGELA CELIS DE ALMEIDA LOPES

Aprovada em: 17.01.97

Comissão julgadora:

Prof. Dr. Natal Antonio Vello

ESALQ/USP

Prof. Dr. Gerhard Bandel

ESALQ/USP

Prof. Dra. Regina Lúcia Ferreira Gomes

UFPI/PI

$$
M a 1-1 \mid 115
$$

Prof. Dr. Natal Antonio Vello Orientador 
Aos meus pais Lucas e Socorro

Aos meus irmãos Eduardo, Cândida

e Cineide

A minha avó (in memorian) e meus tios

DEDICO 


\section{AGRADECIMENTOS}

- A Deus, por tudo;

- Ao Professor Dr. Natal Antonio Vello, pela orientação e ensinamentos importantes no curso e na minha vida profissional;

- Ao Dr. Francisco Rodrigues Freire Filho pela confiança, orientação, apoio e amizade;

- À professora Regina Lúcia Ferreira Gomes pela amigável convivência, carinho e incentivo em todos os momentos que passamos juntas;

- À Coordenadoria de Aperfeiçoamento de Ensino Superior (CAPES), pela concessão da bolsa de estudos;

- Ao CNPq, EMBRAPA e FAPESP pelo financiamento de várias etapas do programa de pesquisas que originaram o germoplasma utilizados nesta dissertação;

- Aos amigos do grupo da soja, Claudio Yuji, Dario Minoru Hiromoto, Fernando Miranda, Francilene Leonel, Gilberto Yokomizo, José Baldin, Joaquim Adelino, Jorge Rámon, Lafayete Luiz da Silva, Luis Fernando Alliprandini, Maurisrael Rocha, Milton Krieger, Mônica Cagnin, Sandra Helena Uneda, Sérgio Augusto Carbonell, pela amizade e auxílio nos trabalhos experimentais;

- Aos funcionários do Setor de Genética Aplicada às Espécies Autógamas, Antônio Roberto Cogo, Claudinei Antônio Didoné, José Roberto Alonso e Marcos Custódio Nekatschalow;

- Às funcionárias da Biblioteca da Genética, Silvana Gregório e Elizabeth dos Santos, pela revisão das referências bibliográficas; 
- As amigas, Maria Teresa do Rêgo Lopes, Adriana Lago e Ranyse Querino pela amizade e afetuosa convivência;

- À todos os amigos de curso, em particular a Wellington Luiz, Rainério Meireles, Rogério Costa Pinto, André, Carlos e Antonio Ismael;

- A Claudio Takeda e Nélson Fonseca pelo auxílio nas análises estatisticas. 


\section{SUMÁRIO}

Página

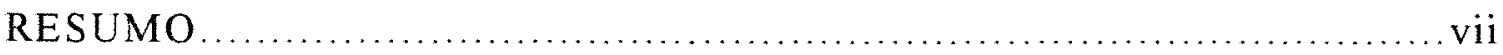

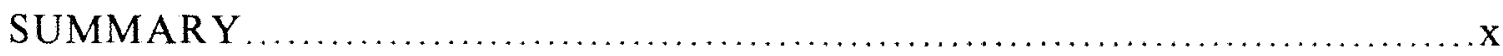

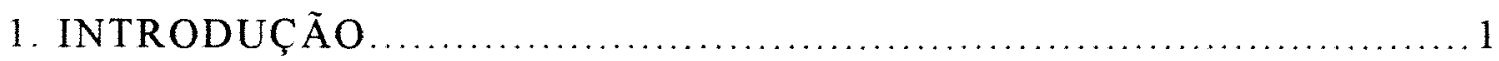

2. REVISÃO DE LITERATURA .................................. 3

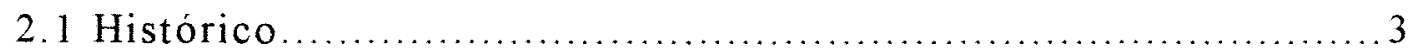

2.2 Considerações sobre os métodos de melhoramento

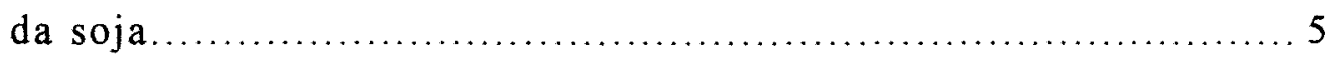

2.30 uso da seleção recorrente na ampliação da base

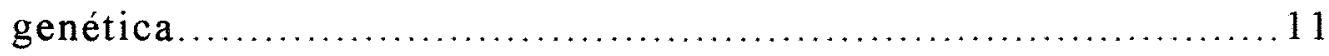

2.4 Herança dos caracteres quantitativos........................... 17

2.4.1 Herdabilidade.......................................... 19

2.4.2 Correlação entre caracteres..............................20

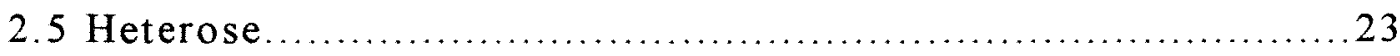

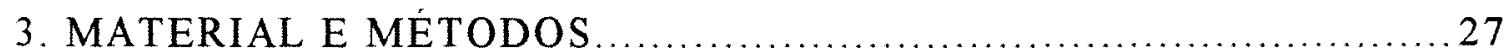

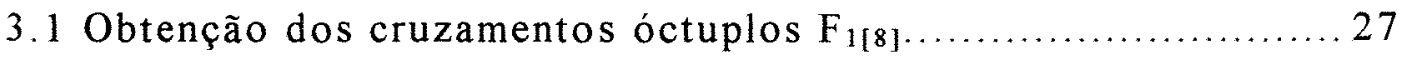

3.2 Instalação do experimento..................................... 29

3.3 Caracteres avaliados ......................................... 29

3.4 Análises estatístico-genéticas............................... 30

3.4.1 Análise de variância e covariância.......................... 30 
3.4.2 Cálculo da herdabilidade ................................ 33

3.4 .3 Correlação entre caracteres................................ 33

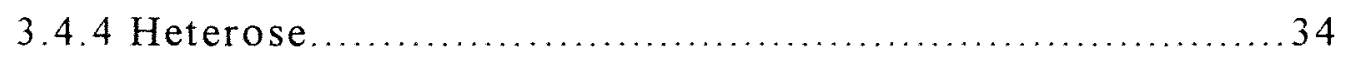

3.4.5 Análise de resíduo ....................................... 35

4. RESULTADOS E DISCUSS ÃO .................................... 36

4.1 Análise de variância............................................ 36

4.2 Análise de parentais......................................... 39

4.2.1 Número de dias para a maturidade....................... 39

4.2.2 Altura da planta na maturidade....................... 40

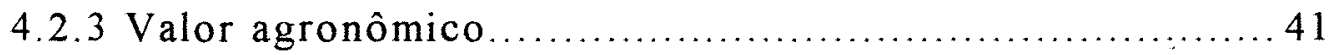

4.2.4 Produtividade de grãos................................. 41

4.3 Análise dos cruzamentos................................ 42

4.3.1 Número de dias para a maturidade..................... 42

4.3.2 Altura da planta na maturidade......................... 45

4.3 .3 Valor agronômico................................... 47

4.3.4 Produtividade de grãos................................. 49

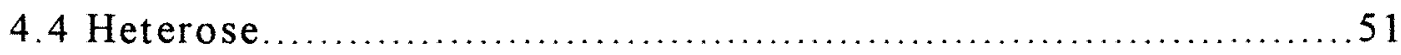

4.5 Correlação entre caracteres...................................5 53

5. CONCLUSÕES .................................................... 55

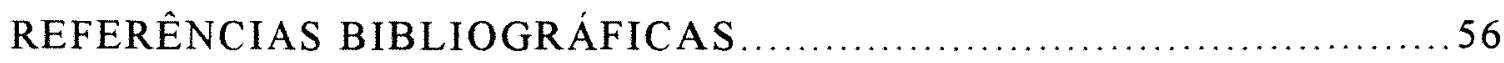

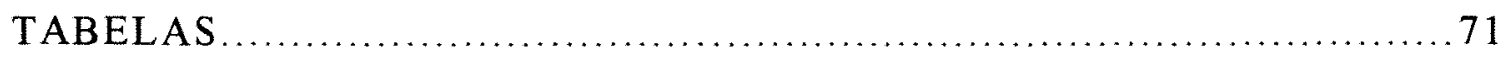

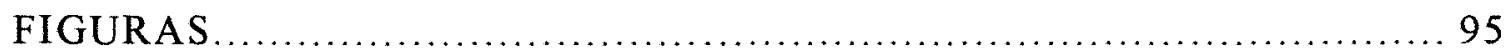

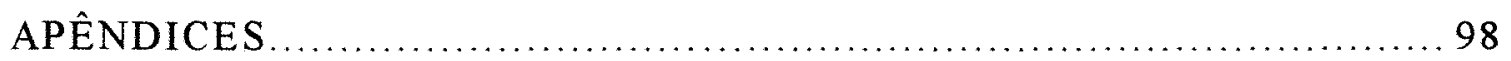


POTENCIALIDADE DE CRUZAMENTOS ÓCTUPLOS DE SOJA COM ÊNFASE NA PRODUTIVIDADE DE GRÃOS

\author{
Autor: Ângela Celis de Almeida Lopes \\ Orientador: Natal Antonio Vello
}

\title{
RESUMO
}

Este trabalho teve por objetivo avaliar a potencialidade de cruzamentos óctuplos [8] em soja [Glycine max (L.) Merrill], visando a seleção de cruzamentos superiores com ênfase na produtividade de grãos. Foram utilizados 40 parentais e a geração $F_{1[8]}$, de 60 cruzamentos óctuplos obtidos pelo programa de seleção recorrente conduzido no Setor de Genética Aplicada às Espécies Autógamas do Departamento de Genética da ESALQ/USP.

O trabalho iniciou-se com a escolha dos 40 parentais, sendo dez de cada grupo de maturação (precoce, semi-precoce, semi-tardio e tardio). A primeira recombinação envolveu quatro dialelos com a obtenção de 180 $F_{1}$ 's, sendo $45 F_{1}$ 's entre parentais precoces, $45 F_{1}$ 's entre semi-precoces, $45 \mathrm{~F}_{1}$ 's entre semi-tardios e $45 \mathrm{~F}_{1}$ 's entre parentais tardios. A segunda recombinação compreendeu 90 cruzamentos entre os $F_{1}{ }^{\prime} s$, combinando-se um $F_{1}$ do dialelo precoce com outro $F_{1}$ do dialelo semi-precoce, da mesma forma foi feito com os $F_{1}$ 's do dialelo semi-tardio e tardio, obtendo-se 45 cruzamentos quádruplos (precoces $x$ semi-precoces) e 45 cruzamentos quádruplos (semi-tardios $\mathrm{x}$ tardios). A terceira recombinação envolveu 60 cruzamentos entre os $F_{1[4]}$ s, combinando-se um $F_{1[4]}$ (precoce $x$ 
semi-precoce) com outro $F_{1[4]}$ (semi-tardio $x$ tardio), conseguido-se 60 cruzamentos óctuplos [8].

Os 40 parentais e os 60 cruzamentos óctuplos na geração $F_{1[8]}$, foram avaliados no delineamento inteiramente casualizado tendo como parcela experimental uma cova (planta individual), com espaçamento de 80 $\mathrm{cm} \times 80 \mathrm{~cm}$, em área experimental do Departamento de Genética da ESALQ/USP, com transplantio de mudas em 21/12/1992. Os caracteres avaliados foram: número de dias para a maturidade (NDM), altura da planta na maturidade (APM), valor agronômico (VA) e produtividade de grãos (PG)

A análise estatístico-genética foi realizada a partir de dados de plantas individuais, estimando-se médias, amplitudes, variâncias entre plantas, herdabilidades no sentido amplo, coeficiente de variação experimental e heterose. Realizou-se também análises de variância e covariância para estimação de correlações fenotípicas, genotípicas e ambientais .

Os resultados conduzem às seguintes conclusões: a) cruzamentos óctuplos entre parentais envolvendo os quatro grupos de maturação (precoce, semi-precoce, semi-tardio e tardio) proporcionaram elevada variabilidade genética nas plantas da geração $F_{1[8]}$, produzindo segregantes superiores nos quatro caracteres avaliados; b) três cruzamentos (C11, C46, C54; Apêndices 1 e 2) destacaram-se por apresentarem altas herdabilidades para os caracteres NDM, APM e PG; c) 14 cruzamentos $(\mathrm{C} 07, \mathrm{C} 14, \mathrm{C} 18, \mathrm{C} 20, \mathrm{C} 22, \mathrm{C} 23, \mathrm{C} 28, \mathrm{C} 29, \mathrm{C} 34, \mathrm{C} 36, \mathrm{C} 39, \mathrm{C} 47, \mathrm{C} 50$ e C58; Apêndices 1 e 2) apresentaram altos valores de herdabilidade para os quatro caracteres, bem como NDM variando de 118 a 132 dias, APM superior a $60 \mathrm{~cm}$, VA de 3,0 a 3,5 e PG maior que $87,81 \mathrm{~g} /$ planta; d) as maiores herdabilidades médias foram conseguidas para os caracteres APM e PG; e) a heterose apresentou ampla variação, destacando-se o caráter PG com a maior heterose média; $f$ ) as correlações genotípicas tenderam a 
ser maiores que as fenotipicas e as de ambiente; $g$ ) plantas $F_{1|8|}$ superiores podem ser selecionadas através do valor agronômico; h) parcelas em covas com espaçamento largo minimizaram a competição intergenotípica e proporcionaram ótima precisão experimental, mas podem ter aumentado o efeito ambiental estimado entre plantas das linhagens parentais para VA e $P G$. 
POTENTIALITY OF EIGHT-WAY CROSSES OF SOYBEANS WITH EMPHASIS IN SEED YIELD

\author{
Author: Ângela Celis de Almeida Lopes \\ Adviser: Natal Antonio Vello
}

\title{
SUMMARY
}

The main objective of this research was to evaluate the potentiality of eight-way [8] crosses of soybeans (Glycine max (L.) Merrill), in order to select superior crosses in seed yield. The material included 40 parents and 60 eight-way $F_{1[8]}$ crosses synthesized by the recurrent selection program carried out in the Setor de Genética Aplicada às Espécies Autógamas, Departamento de Genética, ESALQ/USP.

The work began by chosing 40 parents, with ten parents of each set (early, semi-early, semi-late and late) maturity. The first recombination involved four diallels with obtention of 180 two-ways, including $45 \mathrm{~F}_{1}$ 's between early parents, $45 F_{1}$ 's between semi-early parents, $45 F_{1}$ 's between semi-late parents and $45 \quad F_{1}$ 's between late parents. The second recombination consisted in 45 crosses between $F_{1}$ plants, by combining one $F_{1}$ plant from early diallel and one $F_{1}$ plant from semi-early diallel. After wards was made the same recombination with $F_{1}$ 's plants from semi-late and late diallel; thus, it was obtained 45 four-way crosses, $F_{1[4]}$, (early $x$ semi-early) and 45 four-way crosses (semi-late $x$ late). The third recombination involved 60 crosses between $F_{1[4]}$ 's, by combining one $F_{1[4]}$ 
plant (early $x$ semi-early), with one $F_{1[4]}$ plant (semi-late $x$ late). Thus, it was obtained 60 eight-way crosses.

The parents and $F_{1[8]}$ plants were evaluated in a completely randomized design. The experimental plot was one hill (individual plant), spaced $80 \mathrm{~cm} \times 80 \mathrm{~cm}$, in the experimental area of the Departamento de Genética ESALQ/USP. The characters evaluated were: number of days to maturity (NDM), plant height at maturity (APM), agronomic value (VA) and seed yield $(P G)$.

The genetic-statistical analyses were made with individual plant data, by estimating means, ranges of values, variance between plants, broad sense heritability, experimental coefficient of variation and heterosis. Variance and covariance analyses were carried out for estimating phenotypic, genotypic and environmental correlations.

The results conducted to these conclusions: i) eight-way crosses provided high genetic variability to $F_{1[8]}$ generation, by producing transgressive segregating in NDM, APM, VA and PG; ii) three crosses (C11, C46 and C54; Apêndices 1,2) exceeded by high heritabilites for NDM, APM and PG; iii) the crosses (C07, C14, C18, C20, C22, C23, C28, C29, C34, C36, C39, C47, C50 e C58; Apêndices 1, 2) showed high heritability values for the four caracters, with NDM varing from 118 to 132 days, APM higher than $60 \mathrm{~cm}$, VA from 3.0 to 3.5 and PG higher than $87.81 \mathrm{~g} /$ plant; iv) the largest heritability values were obtained for APM and $\mathrm{PG}$; v) heterosis values showed large variation for all crosses, mainly for PG that showed the greatest mean heterosis; vi) genotypic correlations were larger than phenotypic and environmental correlations; vii) superior $F_{1[8]}$ plants in seed yield may be selected through agronomic value; viii) large-spaced hill plots minimized the intergenotypic competition and provided high experimental precision, but they can have increased the 
environmental effect detected among plants of the parental lines for VA and $P G$. 


\section{INTRODUÇÃO}

A soja (Glycine max (L.) Merrill) é uma das importantes leguminosas cultivadas no mundo. No Brasil, ela ocupa uma posição de destaque sendo cultivada desde os estados do Rio Grande do Sul até o sul dos estados do Maranhão e Piauí. Isso se deve, em grande parte, às pesquisas de genética e melhoramento que têm contribuido de maneira significativa, através da obtenção de genótipos produtivos e com capacidade de adaptação aos diferentes ambientes.

Atualmente, um dos grandes problemas enfrentados pelos melhoristas de soja, no Brasil, diz respeito à estreita base genética, que ocorre devido ao cultivo de genótipos uniformes em uma ampla área geográfica, levando ao estabelecimento de patamares de produtividade e vulnerabilidade genética às condições estressantes (Vello, 1992a).

Uma das formas de reverter essa situação é através da utilização de cruzamentos múltiplos em programas de seleção recorrente, promovendo a recombinação gênica para vários caracteres, gerando maior variabilidade e aumentando o ganho genético. Entende-se por cruzamentos múltiplos, aqueles que envolvem a participação de mais de dois genótipos parentais de constituições gênicas diferentes.

Este trabalho representa uma fase do programa de seleção recorrente para produtividade de grãos do Setor de Genética Aplicada às Espécies Autógamas, do Departamento de Genética, da ESALQ/USP. Foram testados a geração $F_{1[8]}$ de cruzamentos óctuplos e 40 parentais de 
soja com ciclos precoce, semi-precoce, semi-tardio e tardio, sendo que em cada cruzamento óctuplo participaram dois parentais de cada grupo, tendo os seguintes objetivos:

a) Avaliar a potencialidade de cruzamentos óctuplos para produtividade de grãos, estudando a variabilidade gerada na geração inicial;

b) Estimar parâmetros genéticos de caracteres agronômicos;

c) Selecionar cruzamentos e parentais superiores, fornecendo informações importantes para continuidade do programa de seleção recorrente envolvendo parentais dos ciclos precoce, semi-precoce, semi-tardio e tardio. 


\section{REVISÃO DE LITERATURA}

\subsection{Histórico}

A soja é uma planta autógama e anual pertencente à familia Leguminosae, subfamilia Papilionoidae, tribo Phaseoleae, subtribo Phaseolinae (Glycinineae), gênero Glycine, subgênero Soja e a espécie Glycine max (L.) Merrill, com $2 \mathrm{n}=40$ cromossomos.

No que diz respeito à sua origem, há ainda discordância quanto ao local exato do surgimento da soja cultivada, contudo existe um consenso que a área de origem está localizada na região leste da Ásia. Hymowitz (1970), sugeriu que a domesticação se deu por volta do século XI A.C., na região Nordeste da China. Li (1994), baseado em estudos arqueológicos, na atual distribuição da soja selvagem ( $G$. soja), na análise de isoenzimas e também em dados da literatura, sugeriu que a soja foi domesticada no Nordeste da China, indo desde o Noroeste de Hebei até o centro-sul do Noroeste Chinês. Na região centro-sul da China, provavelmente se localiza o centro primário e na região da Manchúria, um centro secundário de diversidade genética da espécie.

Da Ásia, especificamente do Japão, a soja foi levada à Europa no século XVIII e, posteriormente, no início do século XIX cultivares europeus foram levados à América do Norte e no fim desse mesmo século, à América do Sul (Bonetti, 1981). 
A primeira referência sobre a soja no Brasil data de 1882 , no estado da Bahia. Nas décadas que se seguiram, ela continuou sem grande destaque na economia brasileira, e somente no final da década de 60 seu cultivo alcançou uma larga escala, modificando sua importância tanto no cenário nacional como no internacional.

Em termos mundiais, três paises contribuem com $80 \%$ da produção da soja, sendo eles os Estados Unidos, Brasil e Argentina. A China tem se colocado em quarto lugar, porém a sua presença é inexpressiva no mercado econômico internacional, devido ao consumo de quase toda a sua produção (Miranda, 1994).

No Brasil, a produção concentrou-se na região centro-sul até o início dos anos 80. Atualmente, a soja é produzida desde o Rio Grande do Sul ao Maranhão e da Bahia ao Mato Grosso (Kiihl \& Almeida, 1992). Na área abrangendo, especificamente os estados do Maranhão, Piauí e Tocantins, encontra-se um expressivo potencial de produção agrícola, com $90.000,17.000$ e 13.000 ha plantados, respectivamente. Estimativas preliminares indicam que essa região apresenta a possibilidade de ocupar uma área com cerca de 1,5 milhões de hectares, proporcionando uma produção de 3 milhões de toneladas de soja ao ano (Empresa Brasileira de Pesquisa Agropecuária - EMBRAPA, 1995). Em São Raimundo das Mangabeiras, no estado do Maranhão, na safra de 1993/94, obteve-se uma produtividade média de $5684 \mathrm{~kg} / \mathrm{ha}$ ou 94,7 sacas/ha, para o cultivar Cristalina, possivelmente o recorde brasileiro e talvez o sul-americano. Estes resultados confirmam a adaptação da soja na maioria das regiões brasileiras (Yamada, 1995). Isso se deve, em grande parte, aos trabalhos de melhoramento genético que têm desenvolvido genótipos de soja adaptados às diferentes condições ambientais.

A produção mundial de soja, nos últimos 14 anos, cresceu a uma taxa média anual de $2,11 \%$. Supondo-se a manutenção desse crescimento, 
no ano 2003, a produção mundial de soja deverá atingir 150 milhões de toneladas. Essa estimativa está baseada principalmente, no aumento de área e produtividade, prevalecendo, no caso brasileiro, o aumento de área (EMBRAPA, 1995).

Atualmente, encontra-se muitas dificuldades em aumentar a produtividade de soja; por exemplo, os Estados Unidos têm sua produção estabilizada ao redor dos 55 milhões de toneladas, muito embora a safra de 1994 tenha atingido 69 milhões. A China, também tem estabilizado sua produção ao redor dos 12 milhões de toneladas, sendo que em 1994 atingiu os 16 milhões. O Brasil, ao contrário, evoluiu de uma produção de 14,9 milhões (1991/992) para 24,8 milhões de toneladas (1993/94) (FAO, 1995); isso se deve principalmente à ocupação de imensas àreas agricultáveis inexploradas

Sabe-se, porém, que o cultivo da soja no Brasil enfrenta grandes problemas referentes à limitada diversidade genética entre os cultivares com alta produtividade de grãos, tornando difícil a identificação de genótipos mais produtivos que não tenham ancestrais comuns. Baseado nisso alguns programas de melhoramento da soja visam, principalmente, a ampliação da base genética como forma de sobrepujar patamares de produtividade e evitar o perigo de vulnerabilidade genética do germoplasma a adversidades como doenças e pragas.

\subsection{Considerações sobre os métodos de melhoramento da soja}

O melhoramento da soja pode ser considerado um programa que envolve quatro fases distintas. A primeira fase é representada pela introdução de genótipos e foi iniciada no final do século passado. A segunda, compreende cruzamentos simples entre dois parentais (cruzamentos biparentais), iniciada na década de 40 . A terceira fase 
envolve cruzamentos múltiplos entre oito ou mais parentais, com início na década de 70. E a quarta, relaciona-se à biotecnologia, com início na década de 80 (Vello, 1992b).

O primeiro método de melhoramento utilizado na cultura da soja no Brasil foi a introdução de cultivares e linhagens provenientes do sul dos Estados Unidos, pertencentes aos grupos de maturação $\mathrm{V}$ a $\mathrm{X}$, cujos genótipos apresentavam maior potencial de adaptação às condições tropicais e subtropicais (Vello, 1985). A classificação quanto aos grupos de maturação varia de 000 a $X$, nos quais os cultivares são adaptados a altas e a baixas latitudes (Hartwig, 1973). Esse método é o mais simples e rápido, englobando as etapas de introdução de linhagens, teste de desempenho para caracteres agronômicos, seleção, multiplicação e lançamento das melhores no mercado.

A introdução de plantas continua sendo um importante método para identificação de novos materiais e obtenção de parentais que serão usados no desenvolvimento de novos cultivares, ampliando a base genética do germoplasma brasileiro. Dessa forma, as coleções de germoplasma têm sido uma importante fonte para se obter novos materiais, representando uma reserva de diversidade genética essencial ao melhoramento. Os genótipos existentes nesses bancos são importantes fontes de resistência a pragas e doenças, entre outros caracteres desejáveis (Toledo et al. 1995). Após a utilização de materiais provenientes da introdução, passou-se à etapa de seleção de novos genótipos dentro de populações introduzidas.

Considerando que pelos métodos de introdução e seleção já não era possível obter genótipos diferentes dos existentes, recorreu-se à criação de variabilidade genética através do uso de hibridação pelo cruzamento entre dois ou mais cultivares, objetivando conseguir plantas que reunissem características agronômicas desejáveis. Segundo Kadlec (1991), cruzamentos em soja ainda representam um importante papel na 
criação de novos cultivares. Isso é reforçado pelo fato de que a maioria dos novos cultivares lançados recentemente no mundo foram originados através da hibridação.

A hibridação tem o objetivo de reunir em uma planta genes favoráveis que se encontram em diferentes linhagens; as progênies superiores obtidas são identificadas e usadas como novos cultivares, e possivelmente como parentais de novos cruzamentos. O inconveniente desse método é que um limitado "pool" gênico é usado para cada cruzamento, os ciclos são demorados ( 5 a 10 anos) e o aumento anual na produtividade pode ser pequeno (Rose et al. 1992). Stuber (1980), sugeriu vários tipos de cruzamentos (triplo, múltiplo, retrocruzamentos, cruzamentos dialélicos e cruzamentos em cadeia) como forma de se obter maior variabilidade sendo todos aplicáveis às espécies autógamas.

O uso de cruzamentos múltiplos foi proposto por Harlan e seus colaboradores em 1940, para isso eles envolveram um grande número de parentais, 16 a 32 , que foram utilizados em cruzamentos simples, quádruplos e óctuplos por várias gerações, obtendo-se dessa forma um grande número de recombinações entre genes de diferentes linhagens parentais (Frey, 1976). (Figura 1).

Fehr (1978), também esquematizou a formação de uma população proveniente de intercruzamentos, iniciando com cruzamentos simples de oito parentais, depois com cruzamentos quádruplos e óctuplos seguidos de autofecundação.

Hanson (1959), ressalta a importância do uso de mais de uma geração de intercruzamentos, três ou quatro, pois dessa forma se consegue um maior número de quebra de blocos de ligação e a obtenção de um grande número de recombinações gênicas desejadas. A inclusão de quatro ou mais parentais na população, poderia tanto aumentar seu potencial 
genético como reduzir o tamanho dos blocos de ligação intactos nos parentais.

Cruzamentos múltiplos apresentam várias vantagens em relação à cruzamentos simples, em função do maior número de parentais envolvidos. O número de possiveis alelos desejáveis para cada loco na população aumenta com o número de parentais, ou seja, a probabilidade de que pelo menos um parental tenha a maioria dos alelos favoráveis em cada loco é maior. E uma outra vantagem está relacionada com o número de locos que possivelmente serão heterozigotos. A probabilidade de que parentais homozigóticos tenham diferentes alelos em dois ou mais locos ligados também aumenta nos cruzamentos múltiplos. A heterozigosidade para locos ligados é necessária antes que ocorra a efetiva recombinação entre eles (Fehr, 1987a).

Jensen (1970), cita três dificuldades no melhoramento convencional de cereais: conjunto gênico inicial restrito, endogamia e ausência de intercruzamentos. Esses fatores diminuem a variabilidade e as chances de recombinação genética devido à ligação, intensificada pelos dois últimos fatores. Segundo Alliprandini (1996), apesar do grande e crescente número de coleções de germoplasma, a participação de parentais múltiplos ainda é limitada.

No entanto, de acordo com Vello (1992a), cruzamentos múltiplos já estão sendo utilizados com o objetivo de ampliar a base genética do germoplasma cultivado no Brasil e, ao mesmo tempo, promover o desenvolvimento de novos cultivares.

Alguns estudos mostraram que o uso de um maior número de parentais pode ampliar a variabilidade genética. Matzinger \& Wernsman (1968), em trabalho realizado com fumo, relataram a importância do uso de cruzamentos múltiplos objetivando a máxima recombinação genética. 
Thorne \& Fehr (1970) e Khalaf et al. (1984), mostraram que cruzamentos entre três parentais envolvendo cultivares e PI's podem promover uma importante combinação de variabilidade genética e linhagens altamente produtivas. O primeiro trabalho relatou que $o$ cruzamento [(adaptado $\mathrm{x}$ exótico)] $\mathrm{x}$ adaptado] produziu linhagens mais produtivas que o cruzamento biparental (adaptado $x$ exótico). O segundo mostrou que progênies de cruzamentos entre [(cultivar) x (cultivar x PI)] foram superiores às progênies dos cruzamentos (cultivar $x$ PI) ou [(cultivar $\mathrm{x}$ PI) x (cultivar $\mathrm{x} P \mathrm{P})]$.

Wilcox et al. (1984), visando determinar a variabilidade para caracteres agronômicos entre e dentro de familias $F_{1}$ a partir de cruzamentos entre três parentais, envolvendo PI e cultivares, obtiveram diferenças significativas entre famílias para os caracteres produtividade, número de dias para maturidade e altura da planta. A variabilidade entre linhagens dentro de famílias foi tão expressiva quanto entre famílias. Comprovaram, deste modo, que existem vantagens em se manter a identificação das linhagens $F_{1 ' s}$ em cruzamentos envolvendo três parentais, concentrando a seleção naquelas familias que apresentarem um bom desempenho para caracteristicas importantes.

Bos (1987), estudou diferentes tipos de cruzamentos, envolvendo espécies autógamas. O autor concluiu que, no caso de seleção, os programas de cruzamentos diferentes dos esquemas convencionais (biparentais) merecem maior atenção. Um exemplo foi a seleção em $F_{2}$ onde a freqüência de plantas com genótipos desejáveis teve um aumento de $20 \%$ com o uso de cruzamentos diferentes dos biparentais.

O uso de cruzamentos múltiplos como já citado anteriormente, envolve vários parentais, podendo-se ter três, quatro ou mais. Quando a população é formada pela hibridação de mais de quatro parentais, chama-se população composta. Tal população tem sido bastante usada 
atualmente, principalmente por causa do interesse na população melhorada pela seleção recorrente.

Fehr (1987a) descreve alguns princípios importantes na formação de uma população composta. Estes princípios incluem: (a) necessidade de combinar alelos de todos os parentais na população; (b) o maior número de parentais envolvidos que devem ter um bom desempenho e grande diversidade genética; (c) a contribuição genética de cada parental na população; (d) o tempo necessário para formar a população. Em resumo deve-se envolver o maior número possível de parentais e realizar um número razoável de intercruzamentos proporcionando assim, a recombinação dos genes parentais.

Uma extensa revisão foi feita por Goldringer \& Brabant (1993) relatando a importância do uso de cruzamentos múltiplos no desenvolvimento de populações e sua utilização em programas de seleção recorrente, incluindo inúmeros trabalhos que estão sendo realizados por diversas instituições de outros países. Contudo, em termos de Brasil, esse assunto ainda é pouco estudado apesar da sua importância. Segundo Alliprandini (1996), a avaliação correta de parâmetros inerentes a cruzamentos múltiplos, assume fundamental importância quando se objetiva utilizá-los em programa de seleção recorrente e/ou na ampliação da base genética do germoplasma disponível. 


\subsection{0 uso da seleção recorrente na ampliação da base genética}

Geralmente, os objetivos comuns aos programas de melhoramento são aumentar a produtividade e estabilidade dos novos cultivares. Os novos programas procuram reduzir a resposta aos fatores limitantes, que causam reflexos na produtividade, já nos programas mais antigos desejava-se aumentar a produtividade "per se" (Toledo et al. 1995)

Nas espécies autógamas, o melhoramento sempre foi mais estático, talvez devido à dificuldade de realização de cruzamentos. A estagnação do ganho com a seleção, com o passar dos anos, ocorre porque em muitas espécies os materiais geneticamente superiores são muito aparentados, isto é, a base genética é muito estreita.

A base genética estreita traz dois tipos de problemas: a dificuldade de se obter novos materiais mais produtivos e que não tenham descendentes comuns, e a vulnerabilidade destes aos estresses biológicos e ambientais. Isso ocorre devido ao cultivo de poucos genótipos uniformes em uma ampla área geográfica, sendo que novos patamares para a produtividade e menor vulnerabilidade são conseguidos ao se aumentar a diversidade genética (Vello, 1992a). A principal conseqüência do estreitamento da diversidade genética é a redução das possibilidades de ganhos adicionais na seleção, uma vez que o melhorista passa a manejar um conjunto gênico de tamanho limitado (Hanson, 1959).

A preocupação em se estudar a base genética dos cultivares de soja iniciou-se nos Estados Unidos (Vello, 1985). Gizlice et al. (1994), definiram a base genética de grupos de genótipos que contém $99 \%$ dos genes encontrados nos cultivares norte-americanos lançados entre 1947 e 1988. A base genética foi definida em termos de plantas introduzidas 
(ancestrais) usadas para hibridação e de suas progênies. Eles concluíram que 28 ancestrais e 7 progênies contribuíram com $95 \%$ dos genes encontrados nos atuais cultivares e que até a década de 60,75\% dos genes nos cultivares modernos provinham de 17 progênies.

No Brasil, Vello et al. (1988) estudando 69 cultivares de soja, cujos coeficientes de parentesco variaram de 0 a 1 , verificaram que apenas 11 a 15 diferentes genótipos deram origem a esses cultivares, concluindo que o tamanho efetivo da população é relativamente baixo. Anteriormente, Hiromoto \& Vello (1986), avaliando a base genética de 74 cultivares de soja recomendados para o Brasil, constataram que apenas 11 ancestrais representavam a base genética e que estes eram responsáveis por $89 \%$ do conjunto gênico dos cultivares brasileiros de soja. O estreitamento excessivo da base genética das populações utilizadas no melhoramento da soja constitui-se em um dos principais fatores que pode estar limitando a obtenção de cultivares de soja com potencial superior ao dos cultivares atualmente utilizados.

Uma das formas de aumentar a diversidade genética e ampliar a base genética é a introdução de germoplasma exótico. Em uma definição mais completa, germoplasma exótico é todo material genético que não está completamente adaptado a um determinado ambiente. Desta maneira, o germoplasma exótico pode ser constituído por espécies, cultivares, raças, linhagens, materiais introduzidos de outros ambientes, pertencentes a mesma espécie ou apenas aparentados do material que se deseja melhorar (Vello, 1985).

Alguns estudos mostraram que cruzamentos envolvendo cultivares adaptados e introduções podem levar a um aumento de variabilidade genética bem como à obtenção de linhagens mais produtivas (Thorne \& Fehr, 1970; Khalaf et al., 1984). 
Vello et al. (1984), estudaram a variabilidade genética e o desempenho de populações provenientes do cruzamento entre 40 introduções (PI) e 40 cultivares adaptados; a porcentagem de introduções nas populações foi de 100\%,75\%,50\%, 25\% e 0\%. A população sem genótipo introduzido $(0 \%)$, teve menor variabilidade genética e maior média para o caráter produtividade que as populações com $100,75,50$ e $25 \%$ de genótipos introduzidos. Todas as quatro populações, tendo parentais introduzidos, apresentaram o dobro da variabilidade genética para o caráter produtividade de grãos. É provável que o uso de genótipos introduzidos não proporcione aumento na produtividade a curto prazo e sim a longo, através de múltiplos ciclos de seleção recorrente com diferentes niveis de genótipos introduzidos.

Em geral, os processos de melhoramento têm limitado severamente a diversidade do germoplasma empregado, causando com is so grande uniformidade genética em culturas autógamas, notadamente em soja. Atualmente, uma maior ênfase está sendo dada ao desenvolvimento de populações de base genética ampla que podem ser conduzidas por meio de seleção recorrente. O seu uso leva a uma maior freqüencia de recombinações gênicas, conseguidas a cada ciclo de cruzamentos, que aos poucos amplia a variabilidade genética de uma espécie (Kenworthy \& Brim, 1979).

A seleção recorrente é um método de melhoramento que, em sintese, envolve a obtenção de progênies, avaliação e o intercruzamento das melhores. Os genótipos selecionados de uma população são novamente intercruzados, possibilitando que uma combinação genotípica desejada venha a ocorrer com as sucessivas recombinações gênicas, incluindo-se quebra de blocos gênicos, permitindo a liberação de variabilidade em ciclos posteriores. Assim, através dos ciclos de seleção, aumenta-se a 
freqüência de alelos favoráveis e a oportunidade de identificar linhagens contendo a maioria desses alelos (Fehr, 1987b).

Esse método é amplamente utilizado em plantas alógamas, e seu uso é limitado em autógamas devido, em parte, à dificuldade de se realizar cruzamentos para a recombinação em cada ciclo de seleção. Contudo, os resultados promissores em sorgo, fumo e outras espécies, serviram como uma motivação a mais para se pensar na seleção recorrente como uma alternativa para os limites impostos pela redução da variabilidade genética (Geraldi, 1995). Além da soja, sorgo, fumo, a seleção recorrente tem sido utilizada no melhoramento de diversas culturas tais como: trigo (Macneal et al. 1978), feijão (Fouilloux \& Bannerot, 1988) e arroz (Rangel \& Neves, 1995).

O emprego de seleção recorrente nos programas de melhoramento de soja foi sugerido por Hanson et al. (1967), para contornar os insucessos que vinham ocorrendo, devido à baixa freqüência de novas recombinações gênicas. Tal método tem sido usado com sucesso para aumentar a produtividade (Kenworthy \& Brim, 1977; Sumarno \& Fehr, 1982; Werner \& Wilcox, 1990; Fatmi et al., 1992; Burton \& Carver, 1993 ); porcentagem de proteina e óleo na semente (Brim \& Burton, 1979; Burton \& Brim, 1981), resistência à deficiência de ferro em solos calcáreos (Prohaska \& Fehr, 1981).

Kenworthy \& Brim (1979), avaliando três ciclos de seleção recorrente em relação à produtividade em soja, obtiveram um aumento de $134 \pm 30 \mathrm{~kg} / \mathrm{ha} /$ ciclo na seleção entre progênies $\mathrm{S}_{1}$. Está resposta favorável para o caráter sugere que seleção recorrente pode ser usada para desenvolver populações de maior diversidade genética e produtividade. Da mesma forma, Sumarno \& Fehr (1982), obtiveram um aumento linear médio e significativo na produtividade de $120 \pm 10 \mathrm{~kg} / \mathrm{ha} / \mathrm{ciclo}$ dos genótipos precoces, $24 \pm 9 \mathrm{~kg} / \mathrm{ha} /$ ciclo para os tardios e nenhuma mudança 
significativa nos genótipos intermediários; contudo, não houve mudança consistente nos caracteres dias para maturidade, acamamento, altura da planta, peso de semente, porcentagem de óleo e proteína.

Piper \& Fehr (1987) observaram um ganho genético para o caráter produtividade de $0,3 \pm 1,1$ a $6 \pm 1,1 \mathrm{~g} / \mathrm{m}^{2} / \mathrm{ciclo}$, utilizando diferentes testes e estratégias de intercruzamentos durante vários ciclos de seleção recorrente. Entretanto, o ganho genético com seleção recorrente não foi maior que o ganho $\left(9,6 \pm 1,1 \mathrm{~g} / \mathrm{m}^{2}\right)$ observado no melhoramento convencional.

Weber et al. (1990) obtiveram bons resultados com o uso da seleção recorrente em soja. Neste trabalho, realizou-se uma simulação de seleção recorrente iniciando $\operatorname{com} 2,4,8$ ou 16 parentais, utilizando-se 1 , 2, 4 ou 8 cruzamentos. A variabilidade genética não foi perdida, mesmo quando se trabalhou com um pequeno número de parentais.

Rose et al. (1992) avaliaram o potencial da seleção recorrente para melhorar a produtividade em soja e obtiveram, depois de cinco ciclos de seleção recorrente, um aumento médio na produtividade de $17 \%$ e $54 \%$ para a população básica e para as linhagens selecionadas, respectivamente. O ganho médio por ciclo foi de $128 \mathrm{~kg} / \mathrm{ha}$, ou $5,4 \%$ em relação à produtividade da população básica.

Uma das limitações do uso de seleção recorrente em soja, como em outras autógamas, é o número de cruzamentos realizados entre os genótipos durante a fase de intercruzamentos. A emasculação e a polinização manual são difíceis e consomem muito tempo, então Brim \& Stuber (1973), propuseram o uso de macho-esterilidade para obter cruzamentos naturais em soja.

Seleção recorrente usando macho-esterilidade facilita os intercruzamentos e tem sido efetiva no aumento da produtividade. Burton 
et al. (1990), utilizando macho-esterilidade, conseguiram um aumento na produtividade de $76,6 \pm 23,8 \mathrm{~kg} / \mathrm{ha} /$ ciclo e de $37,7 \pm 55,7 \mathrm{~kg} / \mathrm{ha} / \mathrm{ciclo}$, em duas populações de soja. Werner \& Wilcox (1990), avaliando plantas $S_{0}$ e utilizando três critérios de seleção, obtiveram um aumento na média da produtividade de $2,8 \pm 2,9 \mathrm{~g} / \mathrm{planta} / \mathrm{ciclo}$. Tinius et al. (1991), relataram um efeito indireto na produtividade a partir da seleção indireta para tamanho de sementes em plantas macho-estéreis. Xu \& Wilcox (1992) observaram uma tendência de redução da produtividade média ao longo dos ciclos. Para Wilcox (1994) a seleção recorrente tem sido usada com sucesso limitado para aumentar a produtividade de grãos; contudo, tem mostrado resultados mais promissores com relação ao desenvolvimento de linhagens precoces ou com alto teor de proteina.

Os benefícios da seleção recorrente compensam qualquer esforço para tornar este método viável. O progresso satisfatório observado nos vários trabalhos para o caráter produtividade de grãos é um indicativo de que este método é perfeitamente aplicável à soja.

Uma estratégia mista de conservação, ampliação e uso de germoplasma, objetivando associar a sintese de populações de soja com base genética ampla com a prática de seleção recorrente para características de elevado valor econômico, tais como produtividade de grãos, está sendo desenvolvida desde 1983 no Departamento de Genética da Escola Superior de Agricultura "Luiz de Queiroz" ESALQ/USP. O sistema de seleção recorrente envolve três gerações de recombinação: cruzamentos biparentais ( $1^{\mathrm{a}}$ recombinação), cruzamentos quádruplos $\left(2^{\mathrm{a}}\right.$ recombinação) e cruzamentos óctuplos ( $3^{a}$ recombinação). As progênies de tais cruzamentos são avançadas à endogamia, avaliadas e selecionadas mediante a metodologia utilizada para cruzamentos biparentais (Vello, 1992b; Figura 2). 


\subsection{Herança dos caracteres quantitativos}

Quando se trabalha com melhoramento genético de qualquer espécie é essencial que se conheça bem as suas principais caracteristicas agronômicas, bem como o controle genético destas. Tais informações dizem respeito à natureza e quantidade de variabilidade genética disponivel para cada caráter.

Por definição, caracteres quantitativos são aqueles controlados por vários genes e/ou muito influenciados pelo ambiente. Desse modo, a grande maioria dos caracteres importantes no melhoramento de soja, como, ciclo da cultura, porte da planta e, principalmente, produtividade de grãos, são exemplos típicos de caracteres quantitativos.

Como regra geral os caracteres dias para florescimento e maturidade em soja, embora considerados de herança quantitativa têm apresentado genes maiores controlando parte significativa de suas expressões. Ao todo, foram descritos cinco genes com alelos independentes afetando esses caracteres, em trabalhos realizados sob condições de dias longos: $E_{1} / e_{1}$ e $E_{2} / e_{2}$ (Bernard, 1971), $E_{3} / e_{3}$ (Buzzell, 1971), $\mathrm{E}_{4} / \mathrm{e}_{4}$ (Buzzell \& Voldeng, 1980) e $\mathrm{E}_{5} / \mathrm{e}_{5}$ (Mc Blain \& Bernard, 1987), sendo que os alelos dominantes determinam o florescimento e maturidade tardios. Sob condições de dias curtos, o controle genético é diferente do verificado em condições de dias longos; Kiihl (1976), Hartwig \& Kiihl (1979), Tisseli Junior (1981), Toledo \& Kiihl (1982) e Bonato (1989) constataram que o florescimento tardio é controlado por genes recessivos.

A herança do caráter altura de planta é predominantemente de natureza quantitativa; contudo, Caviness \& Prongsirivathana (1968), 
mostraram que o caráter é condicionado não só por um gene principal mas, também, por outros de ação menor (modificadores).

Vários trabalhos foram realizados buscando determinar o modo de ação gênica que explicasse a variação genética observada em soja: Horner \& Weber (1956), Leffel \& Weiss (1958), Gates et al. (1960), Freire Filho (1988), Nass (1989), Bonato (1989), Destro (1991) e Pinheiro (1993). Os resultados revelaram a grande importância da variância genética aditiva, sendo em geral o principal componente da variância genética total. Essa constatação é de grande valor, pois a variância genética aditiva é transmitida de geração a geração.

As estimativas de variância de dominância também mostraram-se valiosas em alguns trabalhos: Leffel \& Weiss (1958), Brim \& Cockerham (1961), Leffel \& Hanson (1961), Camacho (1971) e Pacova (1992).

Até mesmo a epistasia, tem se mostrado como fator da variância que merece consideração. Hanson et al. (1967) apresentaram fortes evidências de que a epistasia é uma importante fonte de variabilidade para produtividade. Destro (1991) observou além da variância aditiva, um efeito epistático do tipo aditivo x aditivo. St. Martin (1981), estudando a importância da epistasia no melhoramento de soja, considerando, seleção de linhagens, cruzamentos múltiplos, seguido de intercruzamentos e seleção recorrente, propôs a decomposicão da variância genética em variância genética aditiva e epistática aditiva $\mathrm{x}$ aditiva. Ainda segundo $\mathrm{St}$. Martin (1981) o número de gerações de intercruzamentos não tem efeito na queda da produtividade, exceto quando os locos epistáticos são ligados; tal afirmação é válida para cruzamentos múltiplos seguidos de intercruzamentos. Desse modo, se a epistasia for relevante, as estimativas de ganho genético baseadas só na variância aditiva podem ser enganosas. Então, níveis significativos de epistasia alteram as estratégias de seleção que devem ser aplicadas para maximizar o progresso genético. 


\subsubsection{Herdabilid ade}

Herdabilidade é freqüentemente definida como a proporção da variância total ou fenotípica, que é estritamente devida à variação genética, para uma certa característica (Burton, 1987). A herdabilidade é um dos parâmetros genéticos que mais contribui para o melhoramento genético, pois ela mede a confiabilidade do valor genotípico como indicador do valor reprodutivo. Devido a isso a herdabilidade participa quase sempre de todas as fórmulas relacionadas com a predição de ganho dos métodos de melhoramento e também de inúmeras decisões práticas (Ramalho et al. 1993).

A herdabilidade não é somente uma propriedade do caráter, mas também da população e das condições ambientais às quais os individuos foram submetidos (Falconer, 1987). Dessa forma, a herdabilidade de uma certa característica não é imutável, podendo ser aumentada pela introdução de maior variação genética na população, realizando cruzamentos entre parentais bem contrastantes e utilizando ambientes mais uniformes.

Brim (1973) e Burton (1987) forneceram resultados sobre estimativas de herdabilidade de caracteres quantitativos, avaliados em programas de melhoramento de soja e mostraram que a herdabilidade variou de 3 a $58 \%$ para produtividade de grãos, de 66 a $90 \%$ para a altura de planta e de 75 a $91 \%$ para número de dias para maturidade.

Os valores de herdabilidade no sentido amplo obtidos por Chauhan \& Singh (1984), Freire Filho (1988), Lin \& Nelson (1988), Bonato (1989), Gomes (1995), variaram de 37 a 99\% para número de dias para maturidade. Os três primeiros autores obtiveram valores de 31 a $92 \%$ para altura de planta na maturidade. Chauhan \& Singh (1984) e Freire 
Filho (1988), obtiveram valores de $50 \%$ a $95 \%$ para produtividade de grãos, enquanto Pacova (1992) obteve um valor médio de $37 \%$ e Gomes (1995) obteve valores médios de herdabilidade de $62 \%\left(F_{6}\right)$ a $29 \%\left(F_{7: 6}\right)$.

Para o caráter valor agronômico, Freire Filho (1988) e Pacova (1992), obtiveram valores médios de 80 e $63 \%$, respectivamente e Gomes (1995) valores de 37 a $69 \%$.

A herdabilidade também tem sido utilizada nos programas de seleção recorrente em soja. Fehr \& Ortiz (1975), estimaram uma herdabilidade de $69 \%$ para produtividade de grãos praticando seleção recorrente com teste de produtividade em $S_{1}$. Wilcox \& May (1986), também estimaram herdabilidade no sentido restrito, para o mesmo caráter, variando de 55 a $70 \%$, utilizando plantas individuais de populações $S_{0}$. Já Werner \& Wilcox (1990) estimaram herdabilidade para três ciclos posteriores, utilizando seleção em plantas individuais $\mathrm{S}_{0}$; contudo, as herdadilidades encontradas foram bem menores (6\%).

Burton et al. (1990) obtiveram herdabilidades que variaram de 62 a $43 \%$ em quatro ciclos para o caráter produtividade de grãos. Rose et al. (1992) encontraram uma herdabilidade média de $64 \%$.

\subsubsection{Correlações entre caracteres}

A correlação é uma medida do grau de associação entre dois ou mais caracteres. O seu estudo é fundamental no melhoramento, porque busca aprimorar o material genético para um grupo de caracteres e não para caracteres isolados. O conhecimento das estimativas das correlações entre caracteres é importante tanto nas etapas de planejamento como de avaliação de programas de melhoramento, facilitando, dessa forma, a 
interpretação dos resultados e auxiliando na elaboração de programas mais eficientes no futuro (Johnson et al. 1955b).

A associação entre dois caracteres pode ser avaliada por meio das correlações fenotípica, genética e ambiental (Falconer, 1987). A correlação mensurada diretamente a nível de um experimento é de natureza fenotipica, e tem dois componentes, genético e ambiental, sendo o primeiro mais importante, pois envolve uma associação de natureza herdável. A correlação genética, conforme citado por Vencovsky (1978), pode ser causada pelos efeitos pleiotrópicos dos genes ou por falta de equilíbrio de ligação. A ligação gênica é uma causa transitória, sendo desfeita quando a população atinge o equilíbrio de ligação, ou seja, ela se manifesta principalmente nas primeiras gerações obtidas dos intercruzamentos de parentais divergentes (Falconer, 1987).

Quando dois caracteres apresentam correlação genética positiva, pode-se conseguir ganhos para um selecionando-se o outro caráter. Essa seleção é dita indireta e pode levar a progressos mais rápidos no melhoramento (Cruz \& Regazzi, 1994). A seleção indireta também é denominada resposta correlacionada à seleção.

O ambiente pode provocar correlações tanto positivas como negativas, ou seja, os dois caracteres podem ser influenciados pelas mesmas diferenças ambientais ou pelo mesmo ambiente. Quando o ambiente atua de forma semelhante sobre dois caracteres gera correlação positiva, caso contrário a correlação é negativa.

Diversos trabalhos de estimativas de correlações têm sido feitos com soja, entre eles destacam-se : Weber \& Moorthy, 1952; Johnson et al., 1955b; Anand \& Torrie, 1963; Monteverde, 1984; Freire Filho, 1988; Pacova, 1992; Pinheiro, 1993; Yokomizo, 1994; Santos, 1994; Gomes, 1995 e Alliprandini, 1996. 
Johnson et al. (1955b) e Weber \& Morthy (1952) estimaram correlações genotipicas positivas entre produtividade e maturidade, produtividade e altura da planta, sendo que as correlações genotípicas foram superiores às fenotípicas. As correlações entre os caracteres medidas ao nivel de parcela foram mais consistentes do que as medidas ao nível de plantas individuais. Estudos de correlações entre os caracteres, produtividade e maturidade, geralmente apresentaram estimativas de correlações genotípicas de magnitude de média a alta: 1,05 (Anand \& Torrie, 1963); 0,85 (Freire Filho, 1988); 0,86 (Santos, 1994); 2,16 (Montenegro, 1994); 0,72 (Prado, 1994); 0,86 (Gomes, 1995).

Em relação aos caracteres produtividade de grãos e altura da planta na maturidade vários autores obtiveram correlação genotípica positiva (Johnson et al., 1955b; Weber \& Morthy, 1952; Anand \& Torrie, 1963; Bays, 1964; Santos, 1994; Prado, 1994; Gomes, 1995).

Pacova (1992) e Gomes (1995), obtiveram correlações positivas e altas, maiores que 0,7 , entre produtividade de grãos e valor agronômico. No entanto, Freire Filho (1988), obteve correlações positivas e de pequena magnitude $(0,13$ a 0,52$)$ para os mesmos caracteres.

Alguns trabalhos têm estimado coeficientes de correlação, utilizando seleção recorrente, entre caracteres de importância agronômica, tais como produtividade de grãos e número de dias para a maturidade. Xu \& Wilcox (1992), obtiveram correlação fenotípica altamente significativa entre maturidade e produtividade de grãos, indicando que plantas precoces tendem a ser menos produtivas que as tardias. A baixa produtividade das plantas precoces é consistente com os resultados obtidos por Sumarno \& Fehr (1982) e Werner \& Wilcox (1990). Em ambos estudos, seleção para aumentar a produtividade de grãos resultou em mudança na população no sentido da maturidade mais tardia. Segundo Alliprandini (1996), isso demonstra a necessidade de se avaliar corretamente estas associações e 
adequar, caso necessário, os parâmetros de seleção e/ou técnicas experimentais, obtendo-se assim resultados mais satisfatórios na sintese de populações superiores.

Em geral, há uma grande variação entre as estimativas de correlações entre caracteres em soja; isso é importante porque mostra diferenciação entre o grau de associação dos caracteres de uma população para outra. É lógico que com o acúmulo de informações tem-se um indicativo da direção e magnitude predominante da correlação entre os caracteres, contudo os coeficientes de correlação devem ser mensurados em cada população que está sendo estudada para poder proporcionar maior eficiência na seleção.

\subsection{Heterose}

A heterose é a superioridade do híbrido em relação aos parentais. A sua ocorrência é comum, mas seu nível de expressão é bastante variável.

Quanto à ação gênica responsável pela manifestação da heterose, existem duas teorias para explicá-la. Na primeira, a heterose resulta do acúmulo, no híbrido, de genes dominantes provenientes dos parentais. A segunda, é a teoria da sobredominância, a qual explica a heterose pela própria condição heterozigótica dos locos que controlam o caráter. Assim, em cada loco, o heterozigoto seria superior a qualquer dos homozigotos. Segundo Falconer (1987), a heterose se expressa quando os parentais de um híbrido têm diferentes alelos em um locus e há algum nível de dominância entre eles.

O efeito da heterose tem sido medido de três formas: a) comparação do híbrido com a média dos parentais, chamada de "heterose"; 
b) comparação do híbrido em relação ao parental superior, chamada de "heterobeltiose"; c) comparação do híbrido com cultivares elites, denominada de "heterose padrão".

Nos estudos de heterose tem sido dado ênfase às espécies de fecundação cruzada, tais como o milho, cuja heterose é explorada comercialmente usando cultivares híbridos $F_{1}$. Atualmente, maior atenção tem sido dada para estudos de heterose envolvendo espécies autógamas, motivada em parte, pela possibilidade de desenvolver sistemas efetivos de exploração comercial de cultivares híbridos $F_{1}$, e, também pela possibilidade de sucesso com uso de dados de produtividade desses hibridos, permitindo ao melhorista selecionar os cruzamentos mais promissores (Sarawat et al. 1994).

Wentz \& Stewart (1924), realizaram um dos primeiros estudos sobre heterose em soja. Nesse estudo, o vigor híbrido foi medido na altura da planta e produtividade de grãos. Para altura da planta, os valores de heterose variaram de $-8,7$ a $11,93 \%$; para produtividade, a variação foi de 59,50 a $299,85 \%$, indicando a presença de vigor híbrido para os dois caracteres.

Weiss et al. (1947), avaliaram heterose para a produtividade de grãos na geração $F_{1}$, em casa de vegetação e no campo, porém os resultados não foram concordantes, havendo cruzamentos com valores de heterose altos em uma condição e baixos em outra.

Chauhan \& Singh (1982), estudando a presença de heterose e sua relação com a divergência genética dos parentais, observaram que, em geral, cruzamentos divergentes mostraram alta heterose e que, pelo aumento da divergência entre parentais, há um aumento da heterose. Relataram, ainda, que as progênies que exibiram máxima heterose em $F_{1}$ também apresentaram maior variabilidade em $F_{2}$ (para o caráter 
produtividade essa relação foi evidente) e que a divergência genética entre parentais parece ser essencial para a manifestação da heterose.

Kunta et al. (1985) estimaram a magnitude da heterose para os caracteres produtividade de grãos, número de vagens por planta, peso e altura da planta, apresentando respectivamente valores de $24,6 \%, 18 \%$, $19,5 \%$ e $13,5 \%$. Outro ponto importante estudado foi a interação parentais $x$ anos e progênies $F_{1}$ 's $x$ anos. Os resultados indicaram que os híbridos foram mais estáveis que os parentais para a produtividade e para outros caracteres. Esse comportamento pode ser muito mais vantajoso em relação à produção convencional de linhagens.

No trabalho desenvolvido por Raut et al. (1988), a porcentagem de heterose para produtividade de grãos e seus componentes variou bastante. Valores máximos de heterose foram observados para os seguintes caracteres: produtividade $(86,21 \%)$, número de vagens por planta $(96,91 \%)$ e número de sementes por planta $(110,24 \%)$; já para o caráter número de dias para a maturidade a heterose foi negativa. Os resultados mostraram que a heterose para a produtividade depende essencialmente da sua relação com os demais componentes, tais como, número de vagens e número de sementes por planta.

Altos valores de heterose também foram obtidos por Taware et al. (1990) para o caráter produtividade de grãos, com os valores variando de $65,9 \%$ a $74,5 \%$, em quatro dos seis cruzamentos realizados. Os autores também sugeriram o uso dos cruzamentos que apresentaram os maiores valores de heterose como base para a seleção em programas de melhoramento.

Nawracala \& Konieczny (1991), estudando as características de plantas $F_{1}$ e seus parentais, observaram que para o caráter altura da planta a heterose atingiu valor de $200 \%$; já para número de vagens e de sementes 
por planta, a heterose foi superior a $300 \%$. Em geral, a produtividade apresentou tendência semelhante a dos caracteres número de vagens e sementes por planta. Esses altos valores de heterose podem ser explicados pela não-adaptação dos parentais às condições da região.

Verifica-se então que os valores médios de heterose (13\%) obtidos na soja não justificam a produção de sementes hóbridas. Sua exploração depende do desenvolvimento de um método econômico para produção de sementes híbridas em larga escala. No caso particular da soja, o peso excessivo do grão-de-pólen limita a sua dispersão, tornando impraticável, até o momento, o uso de híbridos comerciais. 


\section{MATERIAL E MÉTODOS}

\subsection{Obtenção dos cruzamentos óctuplos $F_{1[8]}$}

A seleção dos 40 parentais utilizados nos cruzamentos óctuplos foi feita a partir dos resultados obtidos em experimentos conduzidos em três locais (Anhembi, ESALQ e Sertãozinho) (Soldini, 1993), durante os anos de 1983/84 e 1984/85, sendo dez de cada grupo de maturação: precoce, semi-precoce, semi-tardio e tardio. A escolha dos parentais, relacionados no Apêndice 1, baseou-se na divergência existente entre os mesmos (Vello et al. 1988), na capacidade de combinação e nos altos niveis de produtividade (Nass, 1989; Vello 1992b). Contudo para a realização das análises estatístico-genéticas descartou-se quatro parentais, restando 36 , considerado um número bastante representativo.

A primeira geração de recombinação realizada em 1989, envolveu quatro dialelos completos $10 \times 10$, com 45 cruzamentos biparentais para cada grupo de maturação, portanto, 180 cruzamentos no total. A segunda recombinação, realizada em 1990, compreendeu 45 cruzamentos quádruplos entre os híbridos $F_{1}$ dos ciclos precoce com semi-precoce e 45 cruzamentos quádruplos entre os híbridos $F_{1}$ semi-tardios com tardios. A terceira recombinação, realizada em 1991, produziu 60 cruzamentos óctuplos, sendo que em cada cruzamento 
participaram dois parentais de cada grupo (precoce, semi-precoce, semi-tardio e tardio) conforme demonstra o Apêndice 2 e a Figura 2.

Todos os cruzamentos par a par entre os hibridos quádruplos $\left(F_{1[4]}\right)$ foram realizados em telado nos meses de outubro de 1991 a maio de 1992, pois nas condições ambientais de Piracicaba $\left(23^{\circ}\right.$ de latitude e $534 \mathrm{~m}$ de altitude), os telados permitem a realização de cruzamentos diariamente, no período de 10 às 16 horas, durante os meses de setembro a abril, sempre que a umidade relativa do ar não for muito elevada (Vello, 1992b).

Para a realização dos cruzamentos, usaram-se botões florais que deveriam abrir no dia seguinte, como parental feminino, extraindo-se as pétalas com uma pinça de modo a expor o estigma, sem efetuar a emasculação. Enquanto no parental masculino, o pólen foi obtido de flores recém abertas, das quais foi retirada o conjunto estilo-estigma e colocado em contato com o estigma da flor do parental feminino, resultando na polinização controlada. Em seguida, fez-se a identificação do cruzamento com uma etiqueta que continha o código e data do cruzamento. As vagens provenientes dos cruzamentos foram colhidas individualmente à medida que iam atingindo a maturidade, originando sementes $F_{1[8]}$.

Para obtenção de um número máximo de plantas $F_{1[8]}$, as sementes foram colocadas em germinadores. Em 09/12/92, as sementes foram tratadas com fungicida e colocadas para germinar em toalhas de papel, dentro de incubadora à temperatura de $25^{\circ} \mathrm{C}$ e $100 \%$ de U.R. Após a germinação, as plântulas foram colocadadas em copos plásticos de $200 \mathrm{ml}$ contendo uma mistura de terra, adubos orgânico e mineral. 


\subsection{Instalação do experimento}

Em 21/12/92, as plântulas foram transplantadas para covas espaçadas de $80 \mathrm{~cm}$ x $80 \mathrm{~cm}$, no campo experimental do Departamento de Genética da ESALQ/USP, em solo classificado como terra roxa estruturada.

A geração $F_{1[8]}$ e os parentais foram avaliados num experimento inteiramente casualizado com número diferente de repetições, sendo que o número de plantas por cruzamento variou de um a 81 . A parcela foi constituida de uma cova com uma planta.

A simbologia adotada para designar as gerações de cruzamentos óctuplos diferiu da utilizada para cruzamentos simples. Para a geração $F_{1}$ de cruzamentos óctuplos adotou-se o símbolo $F_{1[8]}$, com o índice [8] localizado após o índice da geração em questão, deixando implícito que esta geração originou-se a partir de oito parentais, semelhante ao adotado por Alliprandrini (1996).

\subsection{Caracteres avaliados}

As plantas $F_{1[8]}$ e os parentais foram avaliados individualmente para os seguintes caracteres:

NDM: número de dias para a maturidade; contados da semeadura até aproximadamente $95 \%$ das vagens apresentarem-se maduras;

APM: altura da planta $(\mathrm{cm})$ na maturidade; medida da base da planta até o ápice da haste principal; 
VA: valor agronômico; refere-se à avaliação feita na maturidade com base em uma escala de notas visuais de 1 a 5 , sendo a nota 1 correspondente a uma planta sem valor agronômico e 5 a uma planta com excelentes características agronômicas; por exemplo, para receber nota 5 a planta deve apresentar altura superior a $60 \mathrm{~cm}$, ser vigorosa, porte ereto, ter grande número de vagens cheias, sem debulha das vagens, sem sintomas de doenças e sem defeitos como haste verde e retenção foliar; dados de VA foram transformados para $\sqrt{\mathbf{x + 0 , 5}}$ para aproximar da distribuição normal;

PG: produtividade de grãos em gramas por planta ou $\mathrm{g} / 0,64 \mathrm{~m}^{2}$; correspondendo ao peso de grãos maduros e secos.

\subsection{Análises estatístico-genéticas}

As análises estatístico-genéticas foram realizadas utilizando os procedimentos do programa SAS (1985).

\subsubsection{Análises de variância e covariância}

As análises de variância foram realizadas ao nível de plantas individuais, para cada caráter. 
O modelo matemático adotado foi:

$$
\mathbf{Y}_{\mathbf{i j}}=\mathbf{m}+\mathbf{T}_{\mathbf{i}}+\mathbf{e}_{\mathbf{i j}}
$$

sendo:

$$
\begin{aligned}
& \mathbf{T}_{\mathrm{i}}=\mathbf{P}_{\mathrm{k}}+\mathbf{C}_{\mathrm{m}}+\mathbf{P C}_{\mathrm{km}} \\
& \mathbf{e}_{\mathrm{ij}}=\mathbf{e}_{\mathrm{mj}}+\mathbf{e}_{\mathrm{kj}}
\end{aligned}
$$

em que:

$\mathbf{Y}_{\mathbf{i j}}$ observação do tratamento $\mathbf{i}$ na repetição $\mathbf{j} ; \mathbf{i}=\mathbf{1}, \mathbf{2}, \ldots, \mathbf{I}, \mathbf{j}=\mathbf{1}, \mathbf{2}$, $\ldots, \mathbf{J}$

$\mathbf{m} \quad$ constante inerente à média, $\mathbf{E}(\mathbf{m})=\mathbf{m}$ e $\mathbf{E}\left(\mathbf{m}^{2}\right)=\mathbf{m}^{2}$;

$\mathbf{T}_{\mathbf{i}} \quad$ efeito aleatório do tratamento $\mathbf{i}$; sendo $\mathbf{E}\left(\mathbf{T}_{\mathbf{i}}\right)=0$ e $\mathbf{E}\left(\mathbf{T}_{\mathbf{i}}^{2}\right)=\sigma_{\mathrm{i}}^{2}$;

$\mathbf{P}_{\mathbf{k}} \quad$ efeito fixo do parental $\mathbf{k}$, onde $\mathbf{k}=\mathbf{1}, \mathbf{2}, \ldots, \mathbf{K}$, sendo $\mathbf{E}\left(\mathbf{P}_{\mathbf{k}}\right)=\mathbf{0}$ e $\mathbf{E}\left(\mathbf{P}_{\mathbf{k}}^{2}\right)=\mathbf{P}_{\mathbf{k}}^{2}$

$\mathrm{C}_{\mathrm{m}}$ efeito aleatório do cruzamento $\mathbf{m}$, onde $\mathbf{m}=\mathbf{1}, \mathbf{2}, \ldots, \mathbf{M}$, sendo $\mathbf{E}\left(\mathbf{C}_{\mathrm{m}}\right)=0$ e $\mathbf{E}\left(\mathbf{C}_{\mathbf{m}}^{2}\right)=\sigma_{\mathrm{c}}^{2}$

$\mathbf{P C}_{\mathbf{k m}}$ efeito aleatório do contraste entre o parental $\mathbf{k}$ e o cruzamento $\mathbf{m}$, sendo $\mathbf{E}\left(\mathbf{P C}_{\mathrm{km}}\right)=\mathbf{0}$ e $\mathbf{E}\left(\mathbf{P C}_{\mathrm{km}}^{2}\right)=\sigma_{\mathrm{pc}}^{2}$

$\mathbf{e}_{\mathrm{ij}}$ efeito aleatório do ambiente e/ou do tratamento i na repetição $\mathbf{j}$, sendo $E\left(\mathbf{e}_{i j}\right)=0$ e $E\left(\mathbf{e}_{i j}^{2}\right)=\sigma_{d}^{2}$ 
$\mathbf{e}_{\mathbf{m j}} \quad$ efeito aleatório das plantas do cruzamento $\mathbf{m}$ na repetição $\mathbf{j}$, sendo

$$
\mathbf{E}\left(\mathbf{e}_{\mathrm{mj}}\right)=\mathbf{0} \text { e } \mathbf{E}\left(\mathbf{e}_{\mathbf{m j}}^{2}\right)=\sigma_{1 / \mathrm{c}}^{2}
$$

$\mathbf{e}_{\mathbf{k j}}$ efeito aleatório do ambiente no parental $\mathbf{k}$ na repetição $\mathbf{j}$, sendo

$$
\mathbf{E}\left(\mathbf{e}_{\mathrm{kj}}\right)=\mathbf{0} \text { e } \mathbf{E}\left(\mathbf{e}_{\mathrm{ki}}^{2}\right)=\sigma_{\mathbf{e}}^{2} \text {. }
$$

A partir deste modelo foram desenvolvidas as análises de variâncias, cujas fontes de variação e esperanças matemáticas dos quadrados médios encontram-se na Tabela 1. Através da determinação das esperanças matemáticas dos quadrados médios pôde-se estimar os parâmetros genéticos, fenotípicos e ambientais. Considerou-se dois desdobramentos: o primeiro de tratamentos em parentais, cruzamentos e parentais vs cruzamentos; o segundo de plantas dentro de tratamentos em plantas dentro cruzamentos e plantas dentro de parentais.

$\mathrm{Na}$ Tabela 2 encontra-se o desdobramento de plantas dentro de cada cruzamento com as respectivas esperanças matemáticas dos quadrados médios.

Utilizando os mesmos procedimentos foram realizadas as análises de covariâncias entre os caracteres, cujas fontes de covariação e esperanças dos produtos médios encontram-se na Tabela 3. 


\subsubsection{Cálculo da herdabilidade}

As estimativas dos coeficientes de herdabilidade foram obtidas para plantas dentro de cada cruzamento, através da seguinte expressão:

$$
\hat{\mathbf{h}}^{2}=\frac{\hat{\sigma}_{1 / \mathrm{c}}^{2}}{\hat{\sigma} \frac{2}{\mathrm{~F}_{1 / c}}}
$$

onde:

$\hat{\mathbf{h}}^{2}$ : $\quad$ estimativa da herdadilidade;

$\hat{\sigma}_{1 / \mathrm{c}}^{2}$ : estimativa da variância genética entre plantas individuais (covas) $F_{1[8]}$; vide Apêndice 3;

$\hat{\sigma} \frac{2}{\mathbf{F}_{1 / \mathbf{c}}}$ : estimativa da variância fenotípica entre plantas individuais covas $F_{1[8]} ;$ vide Apêndice 3;

$\hat{\sigma}^{2} \mathbf{e}:$ estimativa da variância ambiental obtida através da média ponderada pelo número de plantas dos parentais; vide Apêndice 3.

\subsubsection{Correlação entre caracteres}

Os coeficientes de correlação fenotípica, genotípica e ambiental, para parentais, cruzamentos e plantas dentro de cruzamento, entre os pares de caracteres, foram obtidos através das respectivas estimativas da 
variância e covariância (Tabela 3 e Apêndices 3 e 4), tendo como base a expressão (Vencovsky \& Barriga, 1992).

$$
r_{x y}=\frac{\operatorname{COV}(X, Y)}{\sqrt{V(X) \cdot V(Y)}}
$$

sendo:

$\operatorname{COV}(\mathrm{X}, \mathrm{Y})$ : covariância entre os caracteres $\mathrm{X}$ e Y;

$\mathbf{V}(\mathrm{X})$ e $\mathrm{V}(\mathrm{Y})$ : variância dos caracteres $\mathrm{X}$ e $\mathrm{Y}$, respectivamente.

\subsubsection{Heterose}

A heterose corresponde à avaliação da geração híbrida em relação à média dos parentais e é dada pela fórmula:

$$
h=\frac{\left(\overline{\mathbf{F}}_{1[8]}-\overline{\mathrm{MP}}\right)}{\overline{\mathrm{MP}}}, \mathbf{1 0 0}
$$

sendo:

$$
\begin{gathered}
\overline{\mathbf{M P}}=\frac{\mathbf{P}_{\mathbf{i}}+\ldots+\mathbf{P}_{\mathbf{j}}}{\mathbf{8}} ; \text { média dos oito parentais de cada cruzamento } \\
\text { óctuplo; }
\end{gathered}
$$

$\overline{\mathbf{F}}_{1[8]}$ : valor médio das plantas de cada cruzamento $F_{1[8]}$. 


\subsubsection{Análise de resíduo}

Os dados do experimento passaram por uma análise de residuo, utilizando os procedimentos do programa SAS, para identificação de plantas com valores destoantes da distribuição geral dos resíduos estandardizados. O descarte de algumas plantas baseou-se nos resíduos da variável produtividade de grãos (PG). Segundo Neter \& Wasserman (1974), o resíduo estandardizado (RE) pode ser definido como:

$$
\mathbf{R E}=\frac{\text { Resí duo }}{\sqrt{\mathbf{Q M}_{\text {erro }}}}
$$

$$
\begin{aligned}
& \text { Resíduo }=e_{i j}=\left[Y_{i j}(\text { observado })-Y_{i j}(\text { esperado })\right] \\
& Y_{i j}(\text { esperado })=m+t_{i}+e_{i j}
\end{aligned}
$$




\section{RESULTADOS E DISCUSSÃO}

As Tabelas 1 a 3 mostram os esquemas de análise de variância e covariância, com as esperanças matemáticas dos quadrados médios e dos produtos médios. Com base na análise de resíduos e usando como referência a produtividade de grãos (PG) foram eliminados os dados de quatro parentais (FT 81-2134, IAC-Foscarin 31, Paraná e BR-11) obtendo-se, assim, uma satisfatória aproximação à distribuição normal dos resíduos e, conseqüentemente, estimativas mais precisas dos parâmetros genéticos

\subsection{Análise de variância}

Na Tabela 4 encontram-se os quadrados médios obtidos nas análises de variância, as médias de tratamentos, parentais e cruzamentos e os coeficientes de variação referentes à geração $F_{1[8]}$ de 60 cruzamentos óctuplos e 36 parentais de soja, para os caracteres número de dias para a maturidade (NDM), altura da planta na maturidade (APM), valor agronômico (VA) e produtividade de grãos (PG). No primeiro desdobramento verifica-se efeito significativo de tratamentos, parentais e cruzamentos para todos os caracteres avaliados; para o contraste parentais vs cruzamentos houve diferença significativa para os caracteres NDM e PG. Essas diferenças mostram variabilidade entre parentais e entre 
cruzamentos; tal fato já era esperado, visto que os 36 parentais pertencem a diferentes grupos de maturação (precoce, semi-precoce, semi-tardio e tardio), esses parentais foram cruzados entre si originando a geração $F_{1[8]}$ com grande variabilidade (considera-se nesse estudo que as plantas de cada cruzamento $F_{1[8]}$ formam uma população $S_{0}$ não endogâmica). Esse resultado demonstra que a seleção pode ser efetiva, uma vez que existem diferenças entre ciclo, altura, valor agronômico e produtividade.

Considerando-se o segundo desdobramento, verifica-se que houve diferença significativa para plantas dentro de cruzamentos. Esse fato também já era esperado, devido ao grande número de parentais envolvidos (8) e com as mais diferentes caracteristicas, favorecendo ao aparecimento de um grande número de segregantes mesmo em uma geração inicial $\left(F_{1[8]}\right)$. A variabilidade encontrada entre e dentro de cruzamentos, indica amplas possibilidades de obtenção de genótipos promissores.

A significância ao nível de $1 \%$ para os quadrados médios de parentais e das plantas $F_{1[8]}$ mostra que há uma grande variabilidade nesse conjunto de parentais e evidencia a possibilidade de formação de uma população de base genética ampla a partir desse material. A significância da comparação entre os grupos, feita através do contraste parentais vs cruzamentos, indica a presença de heterose nos híbridos.

Em termos de médias (Tabela 4), verifica-se que o caráter NDM sofreu uma redução de 7 dias ao se comparar média de cruzamentos (124 dias) e média de parentais (131 dias), revelando uma maior precocidade para o primeiro grupo, apesar de cada cruzamento possuir parentais de quatro ciclos diferentes, pode-se dizer que os ciclos precoce e semi-precoce predominaram. Segundo Bernard (1971) na maioria das populações híbridas a maturidade é afetada por um grande número de genes, sendo esse caráter de herança quantitativa, contudo alguns autores afirmam que NDM é um caráter determinado por poucos genes. Esse autor 
identificou e estudou dois pares de genes independentes $\left(E_{1} / e_{1}, E_{2} / e_{2}\right)$ afetando tempo para florescimento e maturidade; em condições de dias longos os alelos dominantes determinam o florescimento e a maturidade tardios. Houve uma exceção, em que genótipos com locos heterozigotos para os dois genes mostraram maior precocidade, devendo-se talvez ao efeito especifico do duplo heterozigoto. Bonato (1989) obteve resultados contrários, ou seja, precocidade determinada pelo alelo dominante em condições de dias mais curtos que aqueles citados anteriormente. Dessa forma pode-se explicar a menor média (maior precocidade) das populações $F_{1[8]}$ em relação aos parentais.

Quanto ao caráter APM, em média os cruzamentos apresentaram um porte um pouco mais elevado que o grupo de parentais, contudo essa diferença não é significativa.

Em geral não houve diferença significativa na média dos parentais e dos cruzamentos para o caráter VA, sendo que o comportamento agronômico foi considerado de regular a bom.

Quanto ao caráter $P G$, em média os cruzamentos foram mais produtivos $(87,81 \mathrm{~g} /$ planta) que os parentais $(79,40 \mathrm{~g} /$ planta $)$.

Os coeficientes de variação (CV) obtidos para os diferentes caracteres foram considerados relativamente baixos, com valores de $4,0 \%$ (NDM), 9,1\% (APM), 6,5\% (VA) e 19,8\% (PG). Levando em consideração que a unidade experimental adotada foi uma cova, espaçada de $80 \mathrm{~cm}$ x 80 $\mathrm{cm}$, e o delineamento experimental inteiramente casualizado com número de repetições muito variável entre os genótipos, os valores baixos de CV indicam ótima precisão experimental. Tais resultados concordam com os relatados na literatura para experimentos em covas: Gomes (1995) e Alliprandini (1996). O controle adequado do erro experimental pode ser 
explicado, ao menos parcialmente, pela minimização da competição dada pelo espaçamento largo entre plantas geneticamente diferentes.

\subsection{Análise dos parentais}

As Tabelas 5 a 8 mostram os dados do número de plantas avaliadas, valores médios, percentuais em relação à média geral, máximos, mínimos, amplitudes e variância ambiental, dos caracteres NDM, APM, VA e PG referentes aos 36 parentais. Os parentais estão classificados por ciclo para melhor organização dos grupos que compõem cada cruzamento.

\subsubsection{Número de dias para a maturidade}

Os dados relativos ao caráter NDM constam da Tabela 5. Para os parentais, a média geral foi de 130 dias, tendo-se 13 parentais atingindo a maturidade com menos de 120 dias; sete entre 121 e 130 dias; três entre 131 e 135 dias e 13 parentais com mais de 135 dias. Predominando o ciclo precoce (menos de 120 dias), semi-tardio e tardio (mais de 135 dias). O parental mais precoce foi 'Hale 321' (112 dias) e os mais tardios foram 'EMGOPA-301' (149 dias) e 'IAC-6' (149 dias); a diferença de 37 dias entre o parental mais precoce e o mais tardio é considerável. Esses resultados são semelhantes aos encontrados por Freire Filho (1988), tendo como parental mais precoce 'Hale 321' (113 dias); por outro lado, Nass (1989) observou que, 'IAC-6' foi quatro dias mais tardio que 'EMGOPA-301' em cultivo de outono/inverno; Gomes (1995) observou que 'EMGOPA-301' e 'Cristalina' foram os parentais mais tardios, com nove dias a mais que 'IAC-6'. 
A variância ambiental média dos parentais foi de 24,61 dias $^{2}$, oscilando de 0,33 dias ${ }^{2}$ (IAC-12, Cristalina e BR 79-63) a 133,33 dias ${ }^{2}$ (IAC-8), com amplitude de 1 (SOC 81-79, Cristalina, Bossier e BR 79-63) a 20 dias (Forrest e IAC-8). Essa variação revela que alguns genótipos, como por exemplo IAC-8, são mais influenciados pelo ambiente experimental. Valores elevados de variância ambiental para parental também foram encontrados por Gomes (1995) e por Alliprandini (1996), com variância média de 26,90 dias $^{2}$ e 25,64 dias $^{2}$, respectivamente.

\subsubsection{Altura da planta na maturidade}

A avaliação do caráter APM é apresentada na Tabela 6. A média geral dos parentais foi de $71,70 \mathrm{~cm}$, sendo que dos 36 parentais , 27 apresentaram valores de APM maiores que $60 \mathrm{~cm}$. O parental mais baixo foi FT 81-1835 com 37,75 cm e o mais alto foi 'Tropical' com 104,33 cm. A redução em APM, para alguns parentais, pode estar associada a maior quantidade de ramificações em função do menor grau de competição devido ao tipo de parcela adotado (covas espaçadas $80 \mathrm{~cm} \times 80 \mathrm{~cm}$ ).

A variância ambiental média foi de $46,55 \mathrm{~cm}^{2}$, oscilando de 1,33 $\mathrm{cm}^{2}$ (IAC-10) a $312,50 \mathrm{~cm}^{2}($ Hale-321) e a amplitude entre os valores máximo e mínimo foi de $0($ IAC-4) a $28 \mathrm{~cm}$ (IAC-2). Tais valores sugerem que esses parentais sofreram maior influência do ambiente. Valores de variância ambiental relativamente elevados para APM foram observados por: Garland \& Fehr (1981) com variância média de $65,20 \mathrm{~cm}^{2}$, Nass (1989) com 48,40 $\mathrm{cm}^{2}$, Krieger (1992) com 50,70 $\mathrm{cm}^{2}$, Gomes (1995) com $37,08 \mathrm{~cm}^{2}$ e Alliprandini (1996) que apresentou uma variância média de $76,58 \mathrm{~cm}^{2}$ em Piracicaba e $53,73 \mathrm{~cm}^{2}$ em Maracaí. 


\subsubsection{Valor agronômico}

$\mathrm{Na}$ Tabela 7 encontram-se os dados referentes a VA. Os parentais apresentaram média geral de 3,1 , o que significa um comportamento agronômico variando de regular a bom. O parental White Biloxi foi o que apresentou melhor nota $(4,3)$ e 'BR-1' obteve a nota mais baixa (1,5). A variância ambiental média foi de 0,0157 com flutuação de 0,00 (Numbaíra, Bossier e BR-1) a 0,0877 (Hale-321). Vale ressaltar que a avaliação do VA é realizada de maneira subjetiva e envolve vários atributos reunidos em um indice visual que varia em função do avaliador.

\subsubsection{Produtividade de grãos}

Os dados referentes a PG encontram-se na Tabela 8. Os parentais mostraram média de $79,40 \mathrm{~g} / \mathrm{planta}$ os mais produtivos foram: 'Paranagoiana' (130,90 g/planta) e 'Timbira' com (128,40 g/planta), superando a média geral em mais de $50 \%$. Já o parental Forrest revelou-se pouco adaptado por apresentar baixa PG $(28,04 \mathrm{~g} / \mathrm{planta})$, o valor de 'Forrest' como parental reside principalmente na sua resistência ao nematóide de cisto (Vello, 1995).

A variância ambiental média para $P G$ foi de 297,75 (g/planta) ${ }^{2}$, oscilando de 2,95 (GO 81-11046) a 806,47 (g/planta ${ }^{2}$ ) para o parental IAC-11. Os parentais Cristalina $\left(732,49 \mathrm{~g} / \mathrm{planta}^{2}\right)$, IAC-6 (741,50 $\mathrm{g} /$ planta $\left.^{2}\right)$ e IAC-11 $\left(806,47 \mathrm{~g} /\right.$ planta $\left.^{2}\right)$ foram os que apresentaram maior variância ambiental, e com comportamento semelhante ao relatado por Gomes (1995). Alliprandini (1996), também obteve alta variância ambiental para $\mathrm{PG}$, variando de 78,08 a 3199,30 (g/planta $\left.{ }^{2}\right)$ em Piracicaba e 18,92 a 652,53 (g/planta $\left.{ }^{2}\right)$ em Maracaí. Os valores elevados de variância 
ambiental em PG, relativamente a outros caracteres, pode ser explicada pela natureza quantitativa (grande número de genes) do caráter.

Pelos resultados apresentados pode-se observar que, no geral, todos os caracteres foram bastante influenciados pelo ambiente, isso pode ser devido, principalmente, ao reduzido número de plantas de alguns parentais. Segundo Jonhson et al. (1955a), não há muita segurança na precisão de estimativas quando existem pequeno número de dados e que estes normalmente estão sujeitos a grandes erros de amostragem. Uma forma de aumentar a precisão experimental utilizando a parcela em covas, seria mediante o uso de maior número de repetições e utilizar igual número de plantas por genótipo (Green et al., 1974).

\subsection{Análise dos cruzamentos}

As Tabelas 9 a 16 mostram os dados do número de plantas avaliadas, valores médios, percentuais em relação à média geral, máximos, minimos, amplitudes, variâncias genotípicas, fenotípicas e herdabilidades, relacionados aos caracteres número de dias para maturidade (NDM), altura da planta na maturidade (APM), valor agronômico (VA) e produtividade de grãos (PG), referentes aos 60 cruzamentos óctuplos.

\subsubsection{Número de dias para a maturidade}

As Tabelas 9 e 10 mostram os dados obtidos para o caráter NDM na geração $F_{1[8]}$. A média foi de 124,20 dias, havendo uma redução de sete dias em relação aos parentais; esta diferença é significativa, conforme comprova o contraste parentais vs cruzamentos. O controle 
genético do tempo para o florescimento e para a maturidade em soja sob condições de dias curtos é diferente do verificado em condições de dias longos (Bonato, 1989). Sob condições de dias curtos a maturidade precoce é controlado por genes dominantes e o número de genes envolvidos varia de acordo com os genótipos estudados. Neste sentido Xu \& Wilcox (1992) conseguiram uma redução média para a maturidade de 2,7 dias/ciclo, mostrando uma consistente e uniforme diminuição no número de dias em diferentes ciclos de seleção recorrente.

O cruzamento mais precoce foi $\mathbf{C 4 9}$ (identificado nos Apêndices 1 e 2) com 112,30 dias. Já o cruzamento mais tardio foi C13 com 138,70 dias; neste caso, as contribuições dos parentais EMGOPA-301 (22), BR 79-63 (32), Timbira (38) e IAC-11 (23) devem ter proporcionado a formação de uma combinação gênica que tornou esse cruzamento mais tardio. Os cruzamentos $\mathbf{C 3 0}$ a $\mathbf{C 3 5}$, são bastante precoces e apresentam os seguintes parentais em suas genealogias: CEPS-7716 (01), Forrest (03), FT 81-1835 (04), Hale-321 (06) e FT 81-2706 (14), todos com ciclo menor que 121 dias, com exceção do último, que apesar de pertencer ao ciclo semi-precoce apresentou 147 dias para NDM.

No geral, 30 cruzamentos apresentaram valores inferiores à média geral e 26 apresentaram valores superiores, não excedendo $12 \%$, podendo-se dizer que, em média, os cruzamentos se distribuiram dentro dos ciclos precoce e semi-precoce. Há segregantes inferiores à media dos parentais para a maioria dos cruzamentos, com exceção de C07, C11 e C13. Através dos limites máximos, verifica-se que somente foram encontrados segregantes transgressivos superiores ao parental mais tardio em 21 cruzamentos, destacando-se os cruzamentos C07, C11, C13 como os mais tardios, tanto em relação à média dos parentais quanto em relação ao parental mais tardio. Com relação aos valores mínimos, verifica-se que segregantes transgressivos inferiores ao parental mais precoce podem ser 
encontrados em 46 cruzamentos, indicando a possibilidadede de selecionar maior número de genótipos do ciclo precoce (menos de 120 dias) e semi-precoce (120 a 135 dias) nesses cruzamentos.

A variância genotípica média foi de 69,96 dias $^{2}$ e a fenotípica de 94,57 dias $^{2}$. Esses resultados indicam a existência de variabilidade passível de seleção, entre plantas dentro de cruzamentos, reforçado pelas observações dos valores máximos e mínimos. Já a herdabilidade apresentou média de 73,98\%, com oscilação de zero (C16, C35, C40, C43, C53 e C60) a 97,64\% no (C03), esse cruzamento destacou-se não só pela alta herdabilidade, como também por se encontrar abaixo da média geral, mostrando uma certa precocidade (122 dias). As herdabilidades com valores zero resultaram de componentes de variância negativos os quais podem ser devidos ao pequeno número de plantas em alguns cruzamentos (amostragem). Com base nesses resultados, verifica-se que, em geral, as estimativas das herdabilidades foram altas $\left(h^{2}>70 \%\right)$, indicando a importância das causas genéticas na variação fenotípica do caráter NDM. Esses valores altos de herdabilidade e a natureza do caráter NDM, indicam a possibilidade de selecionar para precocidade já nas gerações iniciais nos programas de melhoramento (Alliprandini, 1996).

Ressalta-se que, os cruzamentos C02, C03, C04, C05, C10, C12, C15, C28, C48 e C55 apresentaram NDM com menos de 128 dias, alta variância genotípica e herdabilidade acima de $80 \%$. Valores de herdabilidades com a magnitude observada nesse estudo foram observadas por diversos autores: Xu \& Wilcox (1992), estudando a eficiência da seleção recorrente baseada em plantas $S_{0}$, encontraram herdabilidade média de $81 \%$ na população $\mathrm{C}_{0}$; Prado (1994), encontrou estimativas de herdabilidade oscilando de $47 \%$ a $84 \%$ entre linhagens $F_{8}$; Gomes (1995) encontrou herdabilidade média de $74 \%$ entre progênies $F_{7: 6}$. 
$\mathrm{Na}$ Tabela 10 encontram-se coeficientes de herdabilidade de 15 cruzamentos, considerando apenas os que apresentaram um número maior ou igual a 15 plantas. Essa tabela foi elaborada com o intuito de discutir as estimativas de herdabilidade a partir de dados tomados em amostras mais representativas. Observa-se que os cruzamentos C13, C11, C15 e C12, que possuem os seguintes parentais em comum: EMGOPA-301 (22), BR 79-63 (32) e IAC-Foscarin 31 (07), apresentaram as maiores herdabilidades e também alta variabilidade genética, sugerindo que uma população de base genética ampla a partir dos parentais desses cruzamentos possibilitará maiores ganhos com a seleção.

\subsubsection{Altura da planta na maturidade}

A avaliação do caráter APM é apresentada nas Tabelas 11 e 12 . A média geral dos cruzamentos foi de $75,27 \mathrm{~cm}$, sendo que 26 cruzamentos apresentaram alturas superiores a esse valor. Pode-se observar também que 13 cruzamentos apresentaram altura média menor que $60 \mathrm{~cm}$; no entanto, deve-se considerar que o cultivo em covas de plantas individuais com espaçamento largo reduz significativamente a APM, devido à minimização da competição entre plantas e o maior número de ramificações das plantas. É importante ressaltar que, como ocorreu nos parentais, APM menor que $60 \mathrm{~cm}$ pode ser devida à ausência de genes para periodo juvenil longo e também pelo efeito da data de semeadura. $O$ cruzamento com menor APM foi $\mathbf{C 6 0}(48,00 \mathrm{~cm})$, enquanto o mais alto foi o C29 $(97,24 \mathrm{~cm})$, nesse cruzamento sete parentais apresentaram altura superior a $65 \mathrm{~cm}$.

Segregantes com APM acima das médias dos parentais somente não foram encontrados nos cruzamentos C27, C43, C53 e C60. 
Transgressivos com valores de APM inferiores aos parentais foram observados em todos os cruzamentos, com exceção do C59; segregantes transgressivos com APM superiores aos parentais foram observados em 39 cruzamentos. Este fato indica a existência de novas combinações gênicas dentro dos cruzamentos favorecendo a seleção de plantas com porte inferior ou superior aos seus parentais.

As médias das variâncias genotípicas e fenotípicas foram de $344,09 \mathrm{~cm}^{2}$ e $390,64 \mathrm{~cm}^{2}$, respectivamente. Os dados referentes às amplitudes e variâncias mostram a ocorrência de variabilidade considerável para APM, em razão das diferenças existentes entre os parentais que originaram os cruzamentos. Pode-se observar também que, dentre os 60 cruzamentos, somente nove apresentaram as menores variâncias genotípicas, oscilando de zero a $120,38 \mathrm{~cm}^{2}$; fora essas, todos os valores de variâncias excederam a $128 \mathrm{~cm}^{2}$.

A herdabilidade média para APM foi de $88,08 \%$, variando de zero $(\mathbf{C 2 7}, \mathbf{C 4 3}, \mathbf{C 5 9}$ e C60) a 94,12\% (C46). Os cruzamentos C04, C05, C12, C15, C28, C48 e C55, destacaram-se por apresentar APM superior a $60 \mathrm{~cm}$ e herdabilidade acima de $70 \%$. O valor médio para o coeficiente de herdabilidade encontra-se inserido dentro dos limites relatados por Alliprandini (1996) para cruzamentos quádruplos e são superiores aos obtidos por Gomes (1995) para cruzamentos biparentais.

De acordo com a Tabela 12, pode-se observar que as herdabilidades para APM variaram de $63,45 \%$ no cruzamento C41 a 94,12\% no C46; em geral, esses valores são bastante altos, demonstrando facilidade de seleção para esse caráter.

No grupo com valores menores de herdabilidade, repetem-se, inúmeras vezes a participação dos parentais BR-1 (12), Davis (13), Cristalina (21) e Tropical (39) dentre os diferentes cruzamentos. É 
importante ressaltar que o parental Tropical (39) participa dos cruzamentos $\mathbf{C 4 8}$ e C41 (APM) e C45 e C52 (NDM) que apresentam menores herdabilidades. Tropical tem genes para periodo juvenil longo (Kiihl \& Almeida, 1992). Menor herdabilidade seria conseqüência dos genes recessivos para período juvenil longo que não tem oportunidade de se expressarem em $F_{1}$.

\subsubsection{Valor agronômico}

Nas Tabelas 13 e 14 encontram-se os dados referentes a VA. O valor agronômico médio dos cruzamentos foi de 3,2, apresentando, em geral, um comportamento igual à média dos parentais, indicando desenvolvimento de regular a bom. Valores médios superiores a 3,00 nos cruzamentos, refletiram a utilizacão de parentais elite, proporcionando plantas com elevado VA. A menor nota de VA foi atribuída ao cruzamento C49 $(2,6)$, o que significa um comportamento agronômico apenas regular, sendo que os parentais que deram origem a esse cruzamento apresentaram VA em torno de 3,0. O maior valor de VA foi para o cruzamento C55 (VA $=4,0)$ superando em $24 \%$ a média dos cruzamentos.

Os valores baixos de VA, estiveram associados à presença de plantas com viroses. Segregantes transgressivos com VA superior ao parental de melhor desempenho ocorreram na maioria dos cruzamentos, com as seguintes exceções: C03, C08, C09, C10, C17, C27, C30, C32, C33, C43, C47, C57 e C60. A presença de valores excelentes (VA = 4,0-5,0) só não foram observados nos cruzamentos C03, C10, C17, C27, $\mathbf{C 4 3}$ e C60. Os valores de VA obtidos nesse estudo foram superiores aos encontrados por Freire Filho (1988) e Gomes (1995), semelhantes aos de 
Nass (1989) e Krieger (1992) e inferiores aos obtidos por Alliprandini (1996).

A média da variância genotípica para VA foi de 0,0258 . Já a média da variância fenotípica para VA foi de 0,0414 , oscilando de zero no $\mathbf{C 4 3}$ a 0,1427 no $\mathbf{C 4 9}$. Tais resultados sugerem que há uma ampla variabilidade genética para esse caráter e, por consegüinte, existem perspectivas de sucesso num programa de melhoramento.

As herdabilidades para VA apresentaram considerável amplitude de variação, oscilando de zero (C27, C43, C51, C59 e C60) a 89,03\% (C49); esta variação na herdabilidade pode ser considerada comum em função das diferenças de tipo de população e do ambiente testado. A herdabilidade média para VA foi $62,20 \%$, sendo um pouco inferior aos obtidos para os outros caracteres; isso pode ser explicado pela subjetividade do caráter VA, avaliado visualmente e transformado em uma escala de notas. O caráter VA é próprio de cada experimento e a sua avaliação é função do pesquisador e do comportamento médio dos indivíduos na população. A herdabilidade média concorda com as obtidas por Pacova (1992) que foi de 63\% em $F_{3}$, e Gomes (1995), 69\% em $F_{6}$, sendo superior as obtidas por Alliprandini (1996), 32\% em $F_{2[4]}$ e $33 \%$ em $\mathrm{F}_{3: 2[4]}$. Os cruzamentos $\mathrm{C04}, \mathrm{C35}, \mathrm{C46}, \mathrm{C47}, \mathrm{C48}, \mathrm{C53}, \mathrm{C56}$ e C58 associaram as características de VA médio superior a 3,2 , alta variância genotípica e herdabilidade superior a $60 \%$.

De acordo com a Tabela 14, pode-se observar que as herdabilidades para VA variaram de $20,07 \%$ no cruzamento $\mathbf{C 3 2}$ a $82,68 \%$ no C37. Dentre os cruzamentos com as maiores herdabilidades estão $\mathbf{C 3 7}$ e C34, tendo em comum os parentais SOC 81-79 (10), FT 81-2706 (14), IAC-11 (23) e Timbira (38); provavelmente, houve uma boa combinação gênica entre estes parentais, resultando numa alta herdabilidade. Fato 
semelhante ocorreu para os cruzamentos $\mathrm{C} 08$ e $\mathrm{C} 09$, que compartilharam os parentais IAC-Foscarin 31 (07), Bossier (11) eBR 79-63 (32).

\subsubsection{Produtividade de grãos}

Os dados relativos à produtividade de grãos (PG) da geração $F_{1[8]}$ estão representados nas Tabelas 15 e 16.

Entre as plantas $F_{1[8]}$, a média geral foi de $87,81 \mathrm{~g} / \mathrm{planta}$, sendo que 29 cruzamentos apresentaram $P G$ superiores a esse valor. $O$ cruzamento menos produtivo foi o de número $\mathbf{C 4 9}$ com 49,59 g/planta ( $56 \%$ da produtividade média dos cruzamentos). As amplitudes verificadas demonstraram grandes diferenças dentro dos cruzamentos para PG. Os cruzamentos mais produtivos $(32$ a $75 \%$ superiores à media dos cruzamentos) foram C43 (153,45 g/planta), C54 (121,00 g/planta) e C58 $(116,14 \mathrm{~g} /$ planta); vale ressaltar que o $\mathbf{C 4 3}$ tinha apenas uma planta. Segregantes superiores à média dos parentais foram encontrados em todos os cruzamentos, exceto no cruzamento $\mathbf{C 6 0}$. Quanto aos segregantes transgressivos superiores ao parental mais produtivo, somente não foram encontrados nos cruzamentos C02, C04, C40, C49 e C60.

A média das variâncias genotípicas foi 968,58 (g/planta) ${ }^{2}$ e das variâncias fenotípicas foi de 1266,30 (g/planta) ${ }^{2}$, com variação de zero C43 a 3078,56 (g/planta $)^{2}$ em C05. Os altos valores para a variância genotípica sugerem que há oportunidade de ganhos, em futuros ciclos de seleção recorrente.

A herdabilidade média dos cruzamentos para $P G$ foi de $76,50 \%$, a qual pode ser considerada alta pela natureza do caráter. As menores herdabilidades foram obtidas para os cruzamentos $\mathbf{C 0 2}, \mathbf{C 4 3}$ e $\mathbf{C 6 0}$, com valores considerados nulos; isso ocorreu devido à pequena variabilidade 
genética existente nestes cruzamentos. Um outro fator seria a presença de ligações em associação, que pode estar relacionada ao decréscimo da variância genética após intercruzamentos (Piper \& Fehr, 1987). A maior herdabilidade foi de $90,33 \%$ no cruzamento C05. Essa ampla variação já era esperada, visto que a herdabilidade varia, principalmente, em função da população testada; de fato, a variância genética foi muito diferente entre as 60 populações ou cruzamentos pesquisados. Os valores de herdabilidade aqui encontrados são superiores àqueles de Pacova (1992) e de Gomes (1995) em cruzamentos biparentais. Em trabalhos de seleção recorrente, nos quais é comum uso de cruzamentos múltiplos, herdabilidades variando de 55 a $70 \%$ foram observadas por Wilcox \& May (1986), Burton et al. (1990), Rose et al. (1992) e Alliprandini (1996).

Os cruzamentos $\mathbf{C 4 3}, \mathbf{C 5 4}$ e $\mathbf{C 5 8}$ apresentaram as melhores produtividades, altas variâncias genotípicas e fenotípicas e herdabilidade acima de $80 \%$, mostrando possuir um grande valor para obtenção de genótipos superiores, através da seleção.

$\mathrm{Na}$ Tabela 16 observa-se que as herdabilidades apresentaram valores altos, não aparecendo nenhum cruzamento com herdabilidade inferior a $60 \%$.

Ressalta-se que as herdabilidades obtidas neste trabalho (com exceção de NDM) foram superiores às obtidas por Alliprandini (1996) em populações $F_{2[4]}$ formadas por um esquema de cruzamentos quádruplos. Isso sugere que a inclusão de parentais, envolvendo os quatro ciclos de maturação, em um esquema de cruzamentos óctuplos aumentou a variabilidade genética das populações resultantes. No entanto, segundo Falconer (1989), as estimativas de parâmetros genéticos são propriedades não só da população em estudo, mas também do ambiente e da forma como o fenótipo é medido. Por isso, a comparação entre resultados de diferentes estudos deve ser feita com cautela. 
É importante destacar a ocorrência de altas herdabilidades em diferentes caracteres no mesmo cruzamento: C46 para NDM, APM VA e PG; C54 e C11 para NDM, APM e PG. No geral, os cruzamentos C07, $\mathrm{C} 14, \mathrm{C} 18, \mathrm{C} 20, \mathrm{C} 22, \mathrm{C} 23, \mathrm{C} 28, \mathrm{C} 29, \mathrm{C} 34, \mathrm{C} 36, \mathrm{C} 39, \mathrm{C} 47, \mathrm{C} 50$ e $\mathrm{C} 58$ apresentaram altos valores de herdabilidade para os quatro caracteres estudados (NDM, APM, VA e PG), bem como NDM variando de 118 a 132 dias, APM superior a $60 \mathrm{~cm}, V A$ de 3,0 a 3,5 e $P G$ maior que a média de $87,81 \mathrm{~g} /$ planta. Tais cruzamentos, que se destacaram como os melhores nos diferentes caracteres, devem ser observados nas gerações seguintes.

Já os cruzamentos C06, C32 e $\mathbf{C 4 2}$ apresentaram as menores herdabilidades para NDM, APM e PG e o $\mathbf{C 3 2}$ e $\mathbf{C 4 2}$ para NDM, APM, VA e $P G$.

\subsection{Heterose}

As estimativas de heterose para os caracteres NDM, APM ,VA e PG, encontram-se na Tabela 17.

A heterose média para o caráter NDM foi de $-4,24 \%$, sendo negativa na maioria dos cruzamentos; isso indica que as plantas $F_{1[8]}$ têm tendência de serem mais precoces que os parentais; esta tendência de dominância parcial para a maturidade precoce pode ser explicada pela herança devido a genes dominantes em soja (Bernard, 1971). Os cruzamentos $\mathbf{C 0 8}, \mathbf{C 3 4}$ e $\mathbf{C 4 9}$ apresentaram os maiores valores de heterose, $-11,07 \%,-10,76 \%$ e $-13,43 \%$, respectivamente, destacando-se o C49 por ser o mais precoce (Tabela 9) e apresentar a maior heterose.

Resultados semelhantes foram relatados por: Freire Filho (1988), com heterose média de $-5,1 \% \pm 5,7 \%$; Nass (1989), com $-3,5 \% \pm$ 
$4,3 \%$ e Krieger (1992) de $-6,5 \%$. Contrariamente, Nawracala \& Konieczny (1991), obtiveram plantas $F_{1}$ mais tardias que os respectivos parentais.

O caráter APM apresentou heterose média de $0,47 \%$, sendo que 31 cruzamentos apresentaram heterose positiva com ampla faixa de variação, indo de $0,26 \%$ (C34) a 31,50\% (C42). Entretanto, 29 apresentaram heterose negativa, variando de $-0,31 \%(\mathbf{C 0 3})$ a $-40,88 \%$ (C60). Tal fato pode ser explicado pela eficiência e adaptação dos cultivares utilizados nos cruzamentos, ou seja, materiais bem adaptados às condições locais quando reunidos podem levar à manifestação da heterose nos dois sentidos. Alguns trabalhos indicam que uma pequena porcentagem dos híbridos são significativamente mais altos que o parental de maior altura, mas a maioria mostra que a altura dos híbridos está entre o valor médio dos parentais. Nelson \& Bernard (1984), também relataram ocorrência de pouca heterose significativa e um baixo nível de expressão para o caráter altura da planta.

As estimativas de heterose para VA foram predominantemente positivas, com média de $3,27 \%$ e variação de $-15,25 \%$ no cruzamento $\mathbf{C 1 0}$ a $33,71 \%$ no C59. Freire Filho (1988) encontrou valor inferior, $1,5 \% \pm$ $20,4 \%$; já Nass (1989) obteve valor superior de $8,2 \% \pm 16,8 \%$ para VA.

A heterose média para o caráter PG foi de $12,98 \%$, variando de $-35,49 \%$ no cruzamento $\mathbf{C 4 9}$ a $72,07 \%$ no $\mathbf{C 4 3}$. Destacou-se o C54 com a segunda maior heterose para PG, o segundo mais produtivo (Tabela 15); em seguida, apareceram os cruzamentos C58 e C59. Esses resultados estão de acordo com Freire Filho (1988); Nass (1989) e Krieger (1992).

Observa-se que alguns cruzamentos foram os melhores, com altos valores de heterose, para diferentes caracteres: C59 e o C42 (APM e VA), C59 (APM, VA e PG). 
A presença de heterose indica a existência de diversidade genética entre parentais (Chauhan \& Singh, 1982). Dessa forma, os resultados encontrados para produtividade e para os outros caracteres, indicam que esses grupos de parentais possuem ampla variabilidade, existindo a possibilidade de obtenção de combinações superiores com base genética ampla.

\subsection{Correlação entre caracteres}

A Tabela 18 mostra as estimativas dos coeficientes de correlação fenotípica, genotípica e ambiental entre os caracteres NDM, APM, VA e PG para os grupos dos parentais, cruzamentos e plantas dentro de cruzamentos.

Em geral, as correlações genotípicas tiveram o mesmo sinal e foram superiores às fenotípicas, sendo, ambas, superiores às correlações ambientais. Isso indica que a expressão fenotípica da associação entre os caracteres é diminuida frente às interferências do ambiente, o que atrapalha o processo seletivo.

O caráter NDM apresentou correlações fenotípicas e genotípicas positivas, com magnitudes de moderada a alta $(r>0,4)$ com APM, VA e PG, principalmente para o grupo dos parentais; para os demais grupos, as correlações foram positivas e de menor magnitude. Isso indica que os genótipos mais produtivos foram os mais altos e mais tardios, porém também mostra a possibilidade de se selecionar plantas $F_{1[8]}$ produtivas e de ciclo precoce.

O caráter APM apresentou correlações fenotípicas e genotípicas positivas com VA, com magnitudes de moderada a alta $(r=0,417$ a 0,888$)$ nos três grupos. Associações positivas também foram observadas entre 
APM e PG, contudo de menor magnitude $(r=0,226$ a 0,558$)$. Cruzamentos com plantas mais altas foram associados com maior VA e PG. As correlações fenotípicas e genotípicas entre PG e VA foram altas $(r=0,537$ a 0,732), tanto nos parentais quanto nos cruzamentos e mostra a possibilidade de se selecionar plantas com genes para valores altos de PG, NDM e VA. Tais valores sugerem que o caráter VA pode ser utilizado como referencial para a seleção de genótipos mais produtivos, principalmente nas gerações iniciais de endogamia. Esses resultados concordam com os obtidos por Gomes (1995) para cruzamentos biparentais; no entanto, discordam daqueles relatados por Alliprandini (1996) para cruzamentos quádruplos.

A partir desses resultados constata-se que é possível a obtenção de materiais precoces com boa produtividade, uma vez que as associações entre NDM, APM e PG foram de valor intermediário. 


\section{CONCLUSÕES}

a. Cruzamentos óctuplos entre parentais precoces, semi-precoces, semi-tardios e tardios proporcionaram elevada variabilidade genética na geração $F_{1[8]}$, produzindo segregantes superiores em todos os caracteres (NDM, APM, VA e PG) em $23 \%$ das populações.

b. As maiores variâncias genotípicas e herdabilidades foram conseguidas nos caracteres APM e PG, indicando maiores possibilidades de obtenção de genótipos superiores na seleção para esses caracteres.

c. Todos os caracteres apresentaram heterose, destacando-se o caráter PG.

d. As correlações genotípicas entre caracteres foram maiores que as fenotípicas e as de ambiente, mostrando que a associação fenotípica é diminuída pelo ambiente.

e. Plantas $F_{1[8]}$ superiores em $P G$ podem ser indiretamente selecionadas através do VA.

f. É possível obter plantas precoces com alta PG em muitos cruzamentos.

g. Parcelas em covas com espaçamento largo minimizaram a competição intergenotípica e proporcionaram ótima precisão experimental, mas podem ter aumentado o efeito ambiental estimado entre plantas das linhagens parentais para VA e PG. 


\section{REFERÊNCIAS BIBLIOGRÁFICAS}

ALLIPRANDINI, L. F. Potencialidade de cruzamentos quádruplos de soja com ênfase na produtividade de grãos. Piracicaba, 1996. 174p. Tese (Doutorado) - Escola Superior de Agricultura "Luiz de Queiroz", Universidade de São Paulo.

ANAND, S. C. ; TORRIE, J. H. Heritability of yield and other traits and interrelations among traits In the $F_{3}$ and $F_{4}$ generations of three soybean crosses. Crop Science, v.3, p.508-511, 1963.

BAYS, I. A. Heritability and association of several quantitative characters in segregating populations of soybeans (Glycine max (L.) Merrill). Mississippi, 1975. 91p. Thesis (Ph.D.) - Mississipi State University.

BERNARD, R. L. Two major genes for flowering and maturity in soybeans. Crop Science, v.11, n.2, p.242-244, Mar./Apr. 1971.

BONATO, E. R. Herança do tempo para o florescimento e para a maturidade em variantes naturais de soja (Glycine max (L.) Merrill). Piracicaba, 1989. 166p.Tese (Doutorado) - Escola Superior de Agricultura "Luiz de Queiroz", Universidade de São Paulo. 
BONETTI, L. P.Distribuição da soja no mundo; origem, botânica e distribuição. In: MIYASAKA, S. C. ; MEDINA, S. C. (Ed). A soja no Brasil. Campinas: ITAL, 1981. p.1-6.

BOS, I. How to develop from three-parent a new variety of a self-fertilizing crop? Euphytica, v.36, n.2, p.455-466, 1987.

BRIM, C. A. Quantitative genetics and breeding. In: BERNARD, R. L. ; WEISS, M. G. (Ed). Soybeans: improvement, production and uses. 2.ed. Madison: American Society of Agronomy, 1973. cap.5, p.155-185.

BRIM, C. A. ; BURTON, J. W. Recurrent selection in soybeans. II Selection for increased percent protein in seeds. Crop Science, v.19, n.4, p.494-498, July/Aug. 1979.

BRIM, C. A. ; COCKERHAM, C. C. Inheritance of quantitative characters in soybeans. Crop Science, v.1, n.3, p.187-190, May/June 1961.

BRIM, C. A. ; STUBER, C. W. Application of genetic male sterility to recurrent selection schemes in soybeans. Crop Science, v.13, n.5, p.528-530, Sept./Oct. 1973.

BURTON, J. W. Quantitative genetics: results relevant to soybean breeding. In: WILCOX, J. R. , (Ed). Soybeans: improvement, production and uses. 2.ed. Madison: American Society of Agronomy, 1987. cap.6, p.211-247.

BURTON, J. W. ; BRIM, C. A. Recurrent selection in soybeans. III Selection for increased percent in oil seeds. Crop Science, v.21, n.1, p.31-34, Jan./Feb. 1981. 
BURTON, J. W. ; CARVER, B. F. Selection among $S_{1}$ families vs selfed half-sib or full-sib families in autogamous crops. Crop Science, v.33, p.21-28, 1993.

BURTON, J. W. ; KOINANGE, G. M. K. ; BRIM, C. A. Recurrent selection selfed progeny selection for yield in soybean using genetic male-sterility. Crop Science, v.30, n.3, p.1222-1226, Nov./Dec. 1990.

BUZZELL, R. I. Inheritance of a soybean flowering response to fluorescent daylenght conditions. Canadian Journal of Genetics Citology, v.13, n.4, p. 703-707, 1971.

BUZZELL, R. I. ; VOLDENG, H. D. Inheritance of insensitivy to long daylenghts. Soybean Genetics Newsletter, v.7, p.26-29, Apr. 1980.

CAMACHO, M. L. H. Varianzas geneticas y herediabilidade de caracteristicas vegetativas y reprodutivas da soja (Glycine max (L.) Merrill). Acta Agronomica, v.21, n.4, p.145-152, 1971.

CAVINESS, C. E. ; PRONGSIRIVATHANA, C. Inheritance and association of plant height and its components in soybean cross. Crop Science, v.8, n.2, p.221-224, Mar./Apr. 1968

CHAUHAN, V.S. ; SINGH, B. B. Heterosis and genetics variability in relation to genetic divergence in soybean.Indian Journal of Genetic and Plant Breeding, v.42, n.3, p.324-328, Nov. 1982.

CHAUHAN, V.S. ; SINGH, B. B. Genetic variability and heritability in soybean. Indian Journal of Agricultural Science, v.54, n.4, p.273-276, Apr. 1984.

CRUZ, C. D. ; REGAZZI, A. J. Modelos biométricos aplicados ao melhoramento genético. Viçosa: Imprensa Universitária da UFV, 1994. 390p. 
DESTRO, D. Capacidade de combinação de genótipos de soja (Glycine max(L.) Merrill) apropriados para consumo humano. Piracicaba, 1991. 158p.Tese (Doutorado) Escola Superior de Agricultura "Luiz de Queiroz", Universidade de São Paulo.

Empresa Brasileira de Pesquisa Agropecuária. Centro Nacional de Pesquisa da Soja. Recomendações técnicas para a cultura da soja na região central do Brasil. Londrina, 1995. 149p.

FALCONER, D. S. Introdução à genética quantitativa. Viçosa: Imprensa Universitária da UFV, 1987. 279p.

FAO PRODUCTION YEARBOOK - 1994, v.48, p. 106-107, 1995.

FATMI, A. ; WAGNER, D. B. ; PFEIFFER, T. W. Intermating schemes used to synthesize a population are equal in genetic consequences. Crop Science, v.32, n.1, p.89-94, 1992.

FEHR, W. R. Breeding. In: NORMAN, A. G. (Ed). Soybean: physiology, agronomy and utilization.New York: Academic Press, 1978. p.119-155.

FEHR, W. R. Principles of cultivar development. New York: Macmillan, 1987a. cap.12, p.137-155: Population formation by hybridization.

FEHR,W.R. Principles of cultivar development. New York: Macmillan, 1987b. cap.15, p.172-192. Recurrent selection.

FEHR, W. R. ; ORTIZ, L.B. Recurrent selection for yield in soybeans. Journal of Agriculture of the University of Puerto Rico, v.59, p.222-232, 1975. 
FOUILLOUX, G. ; BANNEROT, H. Selection methods in the common bean (Phaseolus vulgaris). In: GEPTS, P.(Ed). Genetic resources of phaseolus beans. Dordrecht: Kluwer, 1988. p.503-542.

FREIRE FILHO, F. R. Análise genética de um dialelo entre genótipos precoces de soja (Glycine max (L.) Merrill). Piracicaba, 1988. 224p.Tese (Doutorado) - Escola Superior de Agricultura "Luiz de Queiroz", Universidade de São Paulo.

FREY, K. J. Breeding concepts and techniques for self-pollinated crops. Egyptian Journal of Genetics and Citology, v.5, p.184-206, 1976.

GARLAND, M., L. ; FEHR, W. R. Selection for agronomic characters in hill and row plots of soybeans. Crop Science, v.21, p.591-595, July/Aug. 1981.

GATES, C. E. ; WEBER, C. R. ; HORNER, T. W. A linkage study of quantitative characters in a soybean cross. Agronomy Journal, v.52, n. 1, p.45-49, Jan. 1960.

GERALDI, I. O. Seleção recorrente no melhoramento de plantas. In: TALLER INTERNACIONAL SOBRE SELEÇÃO RECORRENTE EM ARROZ , 1.,Goiânia, 1995. Goiânia: EMBRAPA, CNPAF,1995. p.6-17.

GIZLICE, Z. ; CARTER JUNIOR, T. E. ; BURTON, J. W. Genetic base for North American public soybean cultivars released between 1947 and 1988. Crop Science, v.34, n.5, p.1143-1151, Sept./Oct. 1994.

GOLDRINGER, I. ; BRABANT, P.Sélection récurrente chez les autogames pour lamélioration des variétés lignées pures: une revue bibliographique. II. Agronomie, v. 13, p.561-577, 1993 
GOMES, R. L. F. Análise genética de progênies $F_{6}$ e $F_{7: 6}$ de soja obtidas de cruzamentos dialélicos. Piracicaba, 1995. 140p. Tese (Doutorado) - Escola Superior de Agricultura "Luiz de Queiroz", Universidade de São Paulo.

GREEN, D. E. ; SHIBLES, R. M. ; MORAGHAN, B. J. Use of hill-plots and short rows to predict soybean performance under wide- and narrow-row management. Iowa State Journal of Research, v.49, n.1, p.39-46, 1974.

HANSON, W. D. The breakup of inicial linkage blocks under selected mating systems. Genetics, v.44, n.5, p.857-868, Sept. 1959.

HANSON, W. D. ; PROBST, A. H. CALDWELL, B. E. Evaluation of a population of soybean genotypes with implications for improving self-pollinated crops. Crop Science, v.7, n.2, p.99-103, Mar./Apr. 1967.

HARTWIG, E. E. Varietal development. In: CALDWELL, B. E. (Ed). Soybeans: improvement, production and uses. Madiison: American Society of Agronomy, 1973. cap.6, p. 187-210.

HARTWIG, E. E. ; KIIHL, R. A. S. Identification and utilization of a delayed flowering character in soybeans for short-day conditions. Field Crops Research, v.2, p. 145-151, 1979.

HIROMOTO, D. M. ; VELLO, N.A. The genetic base of Brazilian soybean (Glycine max (L.) Merrill) cultivars. Revista Brasileira de Genética, v.9, n.2, p.295-302, 1986.

HORNER, T. W. ; WEBER, C. R. Theoretical and experimental study of self fertilized populations. Biometrics, v.12, n.4, p.404-414, Dec. 1956. 
HYMOWITZ, T. On the domestication of soybean.Economic Botany, v.24, n.4, p.408-421, Oct./Dec. 1970.

JENSEN, N.F. A diallel selective mating system for cereal breeding. Crop Science, v.10, p.629-635, 1970.

JOHNSON, H. W.; ROBINSON, H. F. ; COMSTOCK, R. E. Estimatives of genetic and enviromental variability in soybeans. Agronomy Journal, v.47, n.7, p.314-318. July, $1955 \mathrm{a}$.

JOHNSON, H. W. ROBINSON, H. F. ; COMSTOCK, R. E. Genotypic and phenotypic correlations in soybeans and their implications in selection.Agonomy Journal, v.47, p.477-483, 1955b.

KADLEC, C. M. Hybridization in Glycine max. Soybean Genetics Newsletter, v.18, p.131-133, Apr. 1991.

KENWORTHY, W. J. ; BRIM, C. A. Recurrent selection for yield in soybeans. Soybean Genetics Newsletter, v.4, p.44-46, Apr. 1977.

KENWORTHY, W. J. ; BRIM, C. A. Recurrent selection for yield in soybeans: I. Seed yield. Crop Science, v.19, n.3, p.315-318, May/June 1979.

KHALAF, A. G. M.; BROSMAN, G. D. ; WILCOX, J. R. Use of diverse populations in soybean breeding. Crop Science, v.24, n.3, p.358-360, May/June 1984. 
KIIHL, R. A. S. ; ALMEIDA, L. A. Situação atual e perspectivas do melhoramento genético da soja no Brasil. In: SIMPÓSIO SOBRE A CULTURA E PRODUTIVIDADE DA SOJA, 1., Piracicaba, 1991. Anais. Piracicaba: FEALQ, 1992. p.38-40.

KIIHL, R. A. S. Inheritance studies of two characters in soybean (Glycine max (L.) Merrill); I. resistance to soybean mosaic virus; II. late flowering under short-day conditions. Mississippi, 1976. 56p. Thesis (Ph.D.) - Mississipi State University.

KRIEGER, M. Análise dialélica envolvendo dez parentais semi-precoces de soja (Glycine max (L.) Merrill). Piracicaba, 1992. 65p.Dissertação (Mestrado) - Escola Superior de Agricultura "Luiz de Queiroz", Universidade de São Paulo.

KUNTA, T. ; EDWARDS, L. H. ; MacNEW, R. W. ; DINKINS, R. Heterosis performance and combining ability in soybeans. Soybean Genetics Newsletter, v.12, p. 97-99, Apr. 1985.

LEFFEL, R. C. ; HANSON, W. D. Early generation testing of diallel crosses of soybeans Crop Science, v.1, n.3, p.169-174, May/June 1961.

LEFFEL, R. C. ; WEISS, M. G. Analysis of diallel crosses among ten varieties of soybean.Agronomy Journal, v.50, n.9, p.528-534, Sept. 1958.

LI, F. S. Study on origin and evolution of soybean.Soybean Science, v.13, n.1, p.61-6, 1994. Resumo em CAB Abstracts on CD-ROM, 1993-94

LIN, M. S. ; NELSON, R. L. Relationship between plant height and flowering date in determinate soybean.Crop Science, v.28, n.1, p.27-30, Jan./Feb. 1988. 
MACNEAL, F. H. ; McGUIRE, C. F. ; BERG, M. A. Recurrent selection for grain protein content in spring wheat. Crop Science, v.18, p.779-782, 1978.

MATZINGER, D. F. ; WERNSMAN, E. A. Four cycles of mass selection in a synthetic variety of an autogamous species Nicotiana tabacum L. Crop Science, v.8, n.2 p.239-243, 1968.

Mc BLAIN, B. A. Studies of soybean maturity genes. Dissertation Abstracts Internacional, B. v.45, p.3423-3428, 1985.

Mc BLAIN, B. A. ; BERNARD, R. L. A new gene affecting the time of flowering and maturity in soybeans. The Journal of Heredity, v.78, n.3, p.160-162, May/June 1987.

MIRANDA, M. A. C. de. Seleção recorrente divergente para peso de sementes e porcentagem de óleo em soja com o uso de machoesterilidade genética. Piracicaba, 1994. 112p.Tese (Doutorado) - Escola Superior de Agricultura "Luiz de Queiroz", Universidade de São Paulo.

MONTENEGRO, E. E. Estimativas de parâmetros genéticos, no verão e no inverno, em cruzamentos entre cultivares de soja (Glycine max (L.) Merrill) divergentes quanto à juvenilidade. Viçosa, 1994. 97p. Dissertação (M. S.) - Universidade Federal de Viçosa.

MONTEVERDE, E. Correlaciones fenotipicas y genotipicas entre rendimento, proteina, aceite y otras caracteristicas en soya (Glycine max). Revista de la Facultad de Agronomia, v.13, n.1/4, p.183-214, 1984. 
NASS, L. L. Potencialidade de genótipos de soja (Glycine max (L.) Merrill) para o cultivo de inverno avaliada por cruzamentos dialélicos. Piracicaba, 1989, 112p. Dissertação (Mestrado) - Escola Superior de Agricultura "Luiz de Queiroz", Universidade de São Paulo.

NAWRACALA, J. ; KONIECZNY, G. Heterosis effect in the cool climate of Wiclkopolska region of Poland. Soybean Genetics Newsletter, v.18, p.154-164, Apr. 1991.

NELSON, R. L. ; BERNARD, R. L. Production and performance of hybrid soybeans. Crop Science, v.24, p.549-553, 1984.

NETER, J. ; WASSERMAN, W. Applied linear statistical models: regressions, analysis of variance and experimental designs. Homewood, Richard D. Irwin, 1974. 842p.

PACOVA, B. E. V.Análise genética de progênies segregantes de soja apropriadas para o consumo humano. Piracicaba, 1992. 217p. Tese (Doutorado) - Escola Superior de Agricultura "Luiz de Queiroz", Universidade de São Paulo.

PINHEIRO, J. B. Dialelo parcial entre parentais de soja resistentes e suscetiveis a insetos. Piracicaba, 1993, 143p. Dissertação (Mestrado) - Escola Superior de Agricultura "Luiz de Queiroz", Universidade de São Paulo.

PIPER, T. E. ; FEHR, W. R. Yield improvement in soybean population by utilizing alternative strategies of recurrent selection.Crop Science, v.27, n.2, p.172-178, Mar./Apr. 1987. 
PRADO, L. C. Perspectivas para o melhoramento de linhagens homozigóticas de soja, com ênfase em produção de grãos e teor de proteina. Piracicaba, 1994. 128p. Dissertação (Mestrado) - Escola Superior de Agricultura "Luiz de Queiroz", Universidade de São Paulo.

PROHASKA, K. R. ; FEHR, W. R. Recurrent selection for resistance to iron deficiency chlorosis in soybeans. Crop Science, v.21, n.4, p.524-526, July/Aug. 1981.

RAMALHO, M. A. P.; SANTOS, J. B. dos. ; ZIMMERMANN, M. J. O. de. Genética quantitativa em plantas autógamas; aplicações ao melhoramento do fejoeiro. Goiânia: UFG, 1993. cap.3, p.29-77: Componentes de médias, variâncias e covariâncias.

RANGEL, P.H. N.; NEVES, P.C. F. Seleção recorrente em arroz irrigado no Brasil. In: TALLER INTERNACIONAL SOBRE SELEÇÃO RECORRENTE EM ARROZ, 1., Goiânia, 1995. Goiânia: EMBRAPA, CNPAF, 1995. p.114-128.

RAUT, V.M. ; HALWANKAR, G. B. ; PATIL V.P.Heterosis in soybean. Soybean Genetics Newsletter, v.15, p.57-60, Apr. 1988.

ROSE, J. L.; BUTLER, D. G. ; RYLEY,M. J. Yield improvement in soybeans using recurrent selection. Australian Journal Agricultural Research, v.43, n.1, p.135-144, 1992.

SANTOS, C. A. F. Análise de trilha e estimativas de parâmetros genéticos em progênies $\mathrm{F}_{6}$ de um cruzamento de soja (Glycine max (L.) Merrill). Viçosa, 1994. 71p. Dissertação (M. S.) - Universidade Federal de Viçosa. 
SARAWAT, P.; STODDARD, F. L. ; MARSHALL,D. R. ; ALI, S. M. Heterosis for yield and related characters in pea. Euphytica, v.30, n.1/2, p.39-48, 1994.

SAS Institute Inc. SAS user's guide: statistics. 5 ed. Cary, 1985. 956p.

SOLDINI, G. K. Interação genótipos x locais e correlações entre caracteres com ênfase na produtividade de óleo em soja. Piracicaba, 1993. 136p. Dissertação (Mestrado) Escola Superior de Agricultura "Luiz de Queiroz", Universidade de São Paulo.

ST. MARTIN, S. K. Epistasis and soybean breeding. Soybean Genetics Newsletter, v. 8, p. 104-107, Apr. 1981.

STUBER, C. W. Mating designs, field mursery layouts and breeding records. In: FEHR, W. R. ; HADLEY, H. H. (Ed). Hybridization of crop plants. Madison: American Society of Agronomy/Crop Society of America, 1980. cap.5, p.83-104.

SUMARNO ; FEHR,W. R. Response to recurrent selection for yield in soybeans. Crop Science, v.22, n.2, p.295-299, Mar./Apr. 1982.

TAWARE, S. P.; HALWANKAR, G. B. RAUT, V.M. PATIL, V.P.Hybrid vigor in soybean (Glycine max (L.) Merrill). Indian Journal of Agricultural Sciences, v.60, n. 8, p. $545-546,1990$.

THORNE, J. C. ; FEHR, W. R. Exotic germplasm for yield improvement in 2-way and 3-way soybean crosses. Crop Science, v.10, n.16, p.677-678, Nov./Dec. 1970.

TINIUS, C. N.; BURTON, J. W. ; CARTER JUNIOR, T. E. Recurrent selection for seed size in soybeans I. Response to selection in replicate populations. Crop Science, v.31, p.1137-1141, 1991. 
TISSELI Jr., O. Inheritance study of long juvenile characteristic in soybeans under long and short-day conditions. Mississipi, 1981. 77p .Thesis (Ph. D.) - Mississipi State University.

TOLEDO, J. F. F. de. ; ALMEIDA, L. A. de. ; KIIHL, R. A. S. et al. Genética y mejoramiento. In: EMPRESA BRASILEÑA DE INVESTIGACIÓN AGROPECUARIA. Centro Nacional de Investigación sobre la Soja. El cultivo de la soja en los tropicos: mejoramiento y producción. Roma: FAO, 1995. p. 19-36.

TOLEDO, J. F. F. de. ; KIIHL, R. A. S. Análise do modelo genético envolvido no controle de dias para florescimento em soja. Pesquisa Agropecuária Brasileira, v. 17, n. 4, p. $623-631$, abr. 1982.

VELLO, N.A. Efeitos da introdução de germoplasma exótico sobre a produtividade e relações com a base genética dos cultivares de soja (Glycine max (L.) Merrill). Piraciacaba, 1985. 91p. Tese (Livre-docência) - Escola Superior de Agricultura "Luiz de Queiroz", Universidade de São Paulo.

VELLO, N.A. Ampliação da base genética do germoplasma e melhoramento da soja na ESALQ/USP. In: SIMPÓSIO SOBRE A CULTURA E PRODUTIVIDADE DA SOJA, 1., Piracicaba, 1991. Anais. Piracicaba: FEALQ, 1992a. p.60-81.

VELLO, N.A. Métodos de melhoramento da soja. In: SIMPÓSIO SOBRE A CULTURA E PRODUTIVIDADE DA SOJA, 1., Piracicaba, 1991. Anais. Piracicaba: FEALQ, 1992b. p.41-59. 
VELLO, N.A. Base genética, fontes de genes e métodos de melhoramento para resistência a doenças. In: ENCONTRO SOBRE TEMAS DE GENÉTICA E MELHORAMENTO, 12., Piracicaba, 1995. Anais. Piracicaba: ESALQ, Depto. de Genética, 1995. p.11-23.

VELLO, N.A. ; FEHR, W. R. ; BAHRENFUS, J. B. Genetic variability and agronomic performance of soybean populations developed from plant introdutions. Crop Science, v.24, n.3, p.511-514, May/June 1984.

VELLO, N.A. ; HIROMOTO, D. M. ; AZEVEDO FILHO, A. J. B. V.Coefficient of parentage and breeding of Brazilian soybean germplasm. Revista Brasileira de Genética, v.11, n.3, p.679-97, Sept. 1988.

VENCOVSKY, R. ; BARRIGA, P. Genética biométrica no fitomelhoramento. Ribeirão Preto: Sociedade Brasileira de Genética, 1992. 486p.

VENCOVSKY, R. Herança quantitativa. In: PATERNIANI, E., (Coord). Melhoramento e produção do milho no Brasil. Campinas: Fundação Cargill, 1978. p. 122-201.

WEBER, C. R. ; MOORTHY, B. R. Hereditable and nonhereditable relationships and variability of oil content and agronomic characters in the $F_{2}$ generation of soybean crosses. Agronomy Journal, v.44, n.4, p.202-209, 1952.

WEBER, W. E. ; QUALSET, C. O. WRICKE, G. Selection strategies for improvement of autogamous species. In: BROWN, A. H. D. ; CLEEG, M. T. ; KAHLER, A. L. ; WEIR, B. S. (Ed). Plant population genetics: breeding and genetic resources. Sunderland: Sinauer Associates, 1990. cap.17, p.229-316. 
WEISS, M. G. ; WEBER, C. R. ; KALTON, R. R. Early generation testing in soybeans. Journal of the American Society of Agronomy, v.39, p.791-811, 1947.

WENTZ, J. B. ; STEWART, R. T. Hybrid vigor in soybeans. Journal of the American Society of Agronomy, v.16, n.8, p.534-540, Aug. 1924.

WERNER, B. K. ; WILCOX, J. R. Recurrent selection for yield in Glycine max using genetic male-sterility. Euphytica, v.50, n.1, p.19-26, 1990.

WILCOX, J. R. An efficient recurrent selection breeding method for soybean.In: WORLD SOYBEAN RESEARCH CONFERENCE, 5., Chiang, 1994. Abstracts. Cniang Mai: 1994. p.1.

WILCOX, J. R. ; MAY, M. L. Evaluation of $S_{0}$ progenies from pollinations of male-sterile soybeans. Eurosoya, v.4, p. 5-9, 1986.

WILCOX, J. R. ; KHALAF, A. G. M. ; BROSSMAN, G. D. Variability within and among $F_{1}$ families from diverse three-parent soybean crosses. Crop Science, v.24, n.6, p.1055-1058, Nov./Dec. 1984.

XU, M. ; WILCOX, J. R. Recurrent selection for maturity and percent seed protein in Glycine max based on $\mathrm{S}_{0}$ plants evaluations. Euphytica, v.62, n.1, p.51-57, 1992.

YAMADA, T. Produtividade recorde de soja no sul do Maranhão. Informacões Agronômicas, n.69, p.5-6, mar. 1995.

YOKOMIZO, G. K. Desempenho e variabilidade de topocruzamentos $\mathrm{F}_{5: 4}$ tipo alimento x tipo grão em soja. Piracicaba, 1994. 120 p. Dissertação (Mestrado) - Escola Superior de Agricultura "Luiz de Queiroz", Universidade de São Paulo. 
TABELAS 
Tabela 1 Esquema da análise de variância em delineamento inteiramente casualizado, ao nível de plantas individuais, com as esperanças matemáticas dos quadrados médios referentes a parentais e geração $F_{1|8|}$. Soja, Piracicaba, transplantio em 21/12/92.

\begin{tabular}{|c|c|c|c|c|}
\hline Fontes de Variação & GL & $\mathrm{QM}$ & $\mathrm{F}$ & $\mathrm{E}(\mathrm{QM})$ \\
\hline${\text { Tratamentos }(\mathrm{T})^{1}}^{1}$ & $\mathrm{~T}-1$ & $\overline{\mathrm{QM}_{7}}$ & $\overline{\mathrm{QM}_{7} / \mathrm{QM}_{1}}$ & $\cdots$ \\
\hline Parentais (P) & P-1 & $\mathrm{QM}_{6}$ & $\mathrm{QM}_{6} / \mathrm{QM}_{1}$ & $\sigma_{\mathrm{e}}^{2}+\mathrm{k}_{3} \phi_{\mathrm{p}}^{2}$ \\
\hline Cruzamentos (C) & $\mathrm{C}-1$ & $\mathrm{QM}_{5}$ & $\mathrm{QM}_{5} / \mathrm{QM}_{2}$ & $\sigma_{e}^{2}+\sigma_{1 / c}^{2}+k_{2} \sigma_{c}^{2}$ \\
\hline $\mathrm{P}$ vs $\mathrm{C}$ & 1 & $\mathrm{QM}_{4}$ & $\mathrm{QM}_{4} / \mathrm{QM}_{3}$ & $\sigma_{\mathrm{d}}^{2}+\mathrm{k}_{1} \sigma_{\mathrm{pc}}^{2}$ \\
\hline Plantas/T & $\left(\mathrm{L}_{\mathrm{T}}-1\right) \mathrm{T}$ & $\mathrm{QM}_{3}$ & $\cdots$ & $\sigma_{\mathrm{d}}^{2}$ \\
\hline Plantas/C & $\left(\mathrm{L}_{\mathrm{C}}-1\right) \mathrm{C}$ & $\mathrm{QM}_{2}$ & $\mathrm{QM}_{2} / \mathrm{QM}_{1}$ & $\sigma_{\mathrm{e}}^{2}+\sigma_{1 / \mathrm{c}}^{2}$ \\
\hline Plantas/P & $\left(L_{P}-1\right) P$ & $\mathrm{QM}_{1}$ & $\cdots$ & $\sigma_{\mathbf{e}}^{2}$ \\
\hline
\end{tabular}

${ }^{1}:$ detalhes no Apêndice 3 .

sendo:

$\mathrm{T}, \mathrm{P}, \mathrm{C}$ : número de tratamentos, parentais e cruzamentos, respectivamente;

$\mathrm{L}_{\mathrm{T}}, \mathrm{L}_{\mathrm{C}}, \mathrm{L}_{\mathrm{P}}$ : número médio de plantas por tratamento, cruzamento e parental, respectivamente;

$\mathbf{k}_{1}$ : número médio de plantas nos dois grupos (parentais e cruzamentos);

$\mathbf{k}_{2}$ : $\quad$ número médio de plantas dos cruzamentos;

$\mathbf{k}_{3}$ : $\quad$ número médio de repetições dos parentais;

$\phi_{p}^{2}=\frac{\sum_{i} P_{i}^{2}}{I-1}$ componente quadrático da variação genética entre parentais;

$\sigma_{\mathrm{c}}^{2}$ : variância genética entre cruzamentos;

$\sigma_{\mathrm{pc}}^{2}$ : variância genética do contraste $\mathrm{P}$ vs $\mathrm{C}$;

$\sigma_{1 / \mathrm{c}}^{2}: \quad$ variância genética entre plantas dentro de cruzamentos;

$\sigma_{\mathrm{d}}^{2}: \quad$ variância dentro de tratamentos;

$\sigma_{\mathbf{e}}^{2}$ : variância ambiental (média ponderada entre os parentais). 
Tabela 2 Esquema da análise de variância em delineamento inteiramente casualizado, ao nível de plantas individuais, considerando a soma de quadrados entre plantas dentro de cada cruzamento referentes à geração $F_{1[8]}$. Soja, Piracicaba, transplantio em 21/12/92.

\begin{tabular}{|c|c|c|c|c|}
\hline Fontes de Variação & GL & QM & $\mathrm{F}$ & $E(Q M)$ \\
\hline Plantas $/ \mathrm{C}_{1}$ & $\mathrm{~L}_{1}-1$ & $\mathrm{QM}_{2.1}$ & $\mathrm{QM}_{2.1} / \mathrm{QM}_{1}$ & $\sigma_{\mathrm{e}}^{2}+\sigma_{1 / \mathrm{c} 1}^{2}$ \\
\hline Plantas $/ C_{2}$ & $\mathrm{~L}_{2}-1$ & $\mathrm{QM}_{2.2}$ & $\mathrm{QM}_{2.2} / \mathrm{QM}_{1}$ & $\sigma_{e}^{2}+\sigma_{1 / c 2}^{2}$ \\
\hline . & - & - & . & $\cdot$ \\
\hline - & - & - & - & - \\
\hline Plantas $/ \mathrm{C}_{60}$ & $\mathrm{~L}_{60}-1$ & $\mathrm{QM}_{2.60}$ & $\mathrm{QM}_{2.60} / \mathrm{QM}_{1}$ & $\sigma_{\mathrm{e}}^{2}+\sigma_{1 / \mathrm{c} 60}^{2}$ \\
\hline Plantas/Parentais & & $\mathrm{QM}_{1}$ & & $\sigma_{\mathrm{e}}^{2}$ \\
\hline
\end{tabular}

sendo:

$\mathrm{QM}_{2.1}, \mathrm{QM}_{2.2}, \ldots, \mathrm{QM}_{2.60}$ : quadrados médios de plantas dentro do cruzamentos 1, 2,.., 60 ;

$\sigma_{1 / \mathbf{c}_{1}}^{2}, \sigma_{1 / \mathbf{c}_{2}}^{2}, \ldots, \sigma_{1 / \mathbf{c}_{60}}^{2}$ : variância genética entre plantas dentro de cruzamentos 1 , $2, \ldots, 60$

$\mathrm{L}_{1}, \mathrm{~L}_{2}, \ldots, \mathrm{L}_{60}$ : número de plantas dentro dos cruzamentos $1,2, \ldots, 60$, respectivamente; $\sigma_{\mathrm{e}}^{2}$ : variância ambiental (média ponderada pelo número de plantas). 


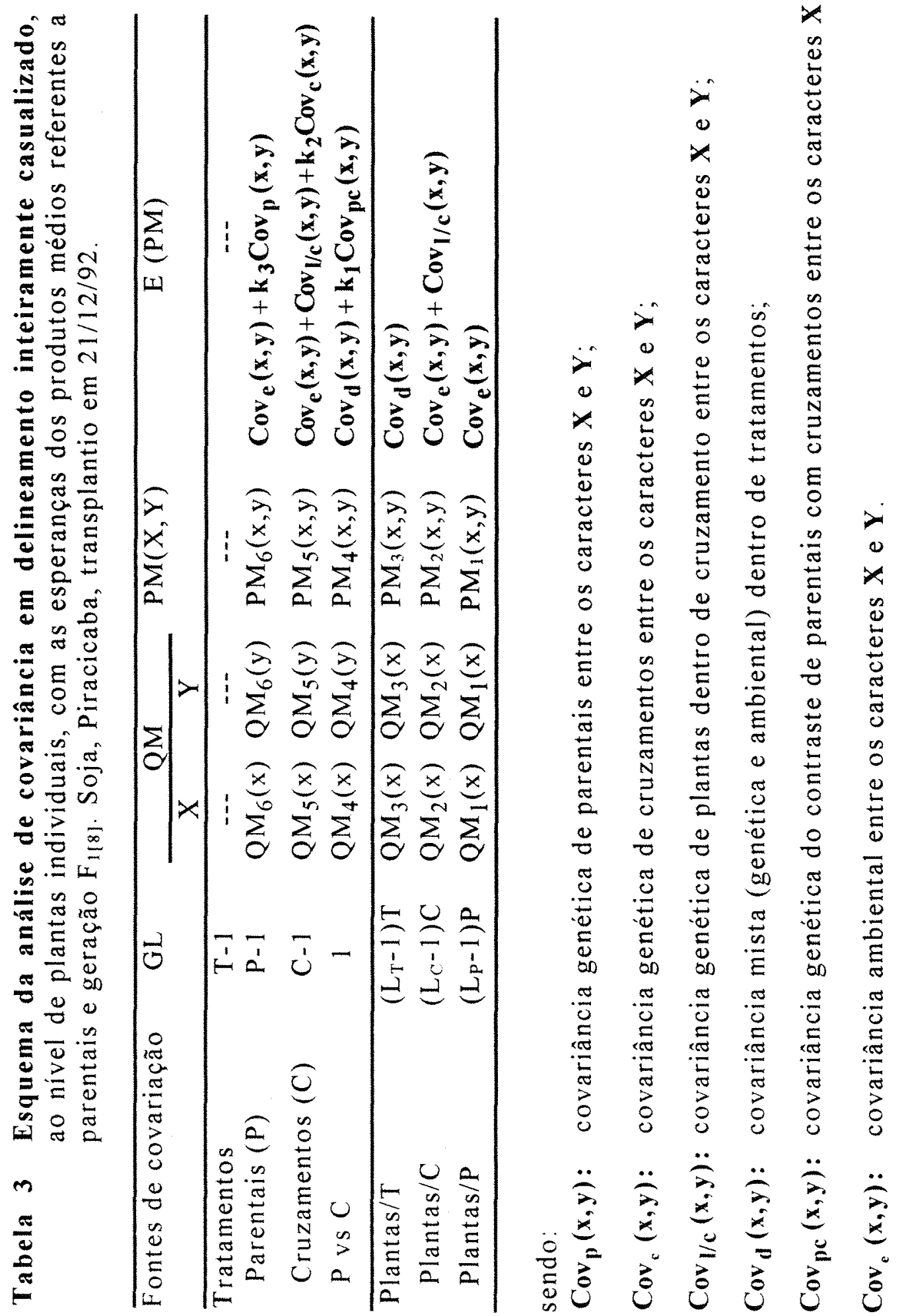


Tabela 4 Quadrados médios obtidos nas análises de variância em delineamento inteiramente casualizado, para os caracteres número de dias para maturidade (NDM), altura da planta na maturidade (APM), valor agronômico (VA) e produtividade de grãos (PG), referentes a parentais e geração $F_{1[8]}$. Soja, Piracicaba, transplantio em 21/12/92.

\begin{tabular}{|c|c|c|c|c|c|c|c|c|c|}
\hline \multirow{2}{*}{ Fontes de Variação } & \multirow[t]{2}{*}{ GL } & \multicolumn{8}{|c|}{ Quadrados Médios } \\
\hline & & \multicolumn{2}{|l|}{ NDM } & \multicolumn{2}{|c|}{$\mathrm{APM}$} & \multicolumn{2}{|l|}{$\mathrm{VA}^{\mathrm{a}}$} & \multicolumn{2}{|l|}{ PG } \\
\hline Tratamentos (T) & 95 & 444,26 & $* *$ & 2022,11 & $* *$ & 0,0867 & $* *$ & 3453,64 & $* *$ \\
\hline Parentais $(\mathrm{P})$ & 35 & 515,57 & $* *$ & 1070,94 & ** & 0,0728 & $* *$ & 2372,20 & $* *$ \\
\hline Cruzamentos (C) & 59 & 340,24 & ** & 2596,57 & ** & 0,0950 & ** & 4020,50 & $* *$ \\
\hline $\mathrm{P}$ vs $\mathrm{C}$ & 1 & 4085,53 & $* *$ & 1420,11 & & 0,0819 & & 7859,33 & $*$ \\
\hline Plantas/T & 1527 & 90,72 & & 371,71 & & 0,0400 & & 1213,05 & \\
\hline Plantas/C & 1443 & 94,57 & ** & 390,64 & ** & 0,0414 & $* *$ & 1266,33 & ** \\
\hline Plantas/P & 84 & 24,61 & & 46,55 & & 0,0157 & & 297,75 & \\
\hline Média Tratamentos & & 124,63 & & 75,01 & & 1,91 & & 87,19 & \\
\hline Média Parentais & & 130,63 & & 71,70 & & 1,89 & & 79,40 & \\
\hline Média Cruzamentos & & 124,18 & & 75,27 & & 1,92 & & 87,81 & \\
\hline CV $(\%)$ & & 4,0 & & 9,1 & & 6,5 & & 19,8 & \\
\hline Unidades & & dias & & $\mathrm{cm}$ & & nota & & $\mathrm{g} /$ planta & \\
\hline
\end{tabular}

*, **: Significativo a $5 \%$ e $1 \%$ de probabilidade, respectivamente, pelo teste $\mathrm{F}$.

a : Análise realizada com dados transformados para $\sqrt{\mathbf{x + 0 , 5}}$ 
Tabela 5 NDM: número de dias para maturidade. Número de plantas $(\mathrm{n})$, média $(\overline{\mathrm{X}})$, porcentagem em relação à média geral dos 36 parentais (\%), valores máximo (máx) e mínimo (min), amplitude $\left(a m p=\right.$ máx - mín) e variância ambiental média $\left(\hat{\sigma}_{\mathbf{e}}^{2}\right)$. Soja, Piracicaba, transplantio em 21/12/92.

\begin{tabular}{|c|c|c|c|c|c|c|c|c|c|}
\hline Pare & ntais & ciclo & $\mathrm{n}$ & $\overline{\mathrm{x}}^{\mathrm{a}}$ & $\%$ & máx & $\min$ & amp. & $\hat{\sigma}_{\mathbf{e}}^{2}$ \\
\hline 01 & CEPS-7716 & $\mathrm{P}$ & 3 & 117,67 & 90,00 & 120 & 116 & 4 & 4,33 \\
\hline 02 & Coker-136 & $\mathrm{P}$ & 2 & 121,50 & 93,00 & 127 & 116 & 11 & 60,50 \\
\hline 03 & Forrest & $\mathrm{P}$ & 5 & 116,20 & 89,00 & 125 & 105 & 20 & 66,70 \\
\hline 04 & FT $81-1835$ & $\mathrm{P}$ & 4 & 116,50 & 89,00 & 125 & 112 & 13 & 35.00 \\
\hline 05 & FT 81-2134 & $\mathrm{P}$ & - & - & - & - & - & - & - \\
\hline 06 & Hale-321 & $\mathrm{P}$ & 2 & 112,00 & 86,00 & 113 & 111 & 2 & 2.00 \\
\hline 07 & IAC-Foscarin 31 & $P$ & - & - & - & - & - & - & - \\
\hline 08 & Paraná & $\mathrm{P}$ & - & - & - & - & - & - & - \\
\hline 09 & Primavera & $\mathrm{P}$ & 4 & 116,50 & 89,00 & 118 & 115 & 3 & 1,67 \\
\hline 10 & SOC $81-79$ & $P$ & 2 & 116.50 & 89,00 & 117 & 116 & 1 & 0.50 \\
\hline 11 & Bossier & SP & 2 & 117,50 & 90,00 & 118 & 117 & 1 & 0,50 \\
\hline 12 & BR-1 & SP & 2 & 122,00 & 94,00 & 125 & 119 & 6 & 18.00 \\
\hline 13 & Davis & SP & 3 & 119,00 & 91,00 & 125 & 115 & 10 & 28,00 \\
\hline 14 & FT $81-2706$ & SP & 4 & 147,50 & 113,00 & 152 & 146 & 6 & 9.00 \\
\hline 15 & GO 81-11046 & SP & 3 & 114,67 & 88,00 & 117 & 111 & 6 & 10,33 \\
\hline 16 & IAC-1 & SP & 4 & 118,25 & 91,00 & 125 & 112 & 13 & 28.92 \\
\hline 17 & IAC-10 & SP & 3 & 119.67 & 92,00 & 125 & 116 & 9 & 22,33 \\
\hline 18 & IAC-12 & SP & 3 & 118,33 & 91,00 & 119 & 118 & 1 & 0.33 \\
\hline 19 & SOC $81-228$ & SP & 4 & 123,75 & 95,00 & 134 & 117 & 17 & 68,92 \\
\hline 20 & Viçoja & $\mathrm{SP}$ & 5 & 119,20 & 92,00 & 125 & 116 & 9 & 12,20 \\
\hline 21 & Cristalina & ST & 3 & 145,67 & 112,00 & 146 & 145 & 1 & 0.33 \\
\hline 22 & EMGOPA-301 & ST & 3 & 149,33 & 115,00 & 155 & 146 & 9 & 24,33 \\
\hline 23 & IAC-11 & $\mathrm{ST}$ & 4 & 131,75 & 101,00 & 134 & 125 & 9 & 20,25 \\
\hline 24 & IAC-4 & ST & 3 & 132,33 & 102,00 & 134 & 129 & 5 & 8.33 \\
\hline 25 & IAC-5 & ST & 4 & 129,00 & 99,00 & 134 & 123 & 11 & 34,00 \\
\hline 26 & IAC- 6 & ST & 5 & 148,60 & 114,00 & 155 & 146 & 9 & 13.80 \\
\hline 27 & IAC- 8 & ST & 3 & 138,33 & 106,00 & 145 & 125 & 20 & 133,33 \\
\hline 28 & IAC-9 & ST & 2 & 142,50 & 109.00 & 145 & 140 & 5 & 12.50 \\
\hline 29 & Santa Rosa & ST & 3 & 136,33 & 105,00 & 146 & 129 & 17 & 76,33 \\
\hline 30 & SS-1 & ST & 5 & 126,40 & 97,00 & 134 & 123 & 11 & 18,80 \\
\hline 31 & BR-11 & $\mathrm{T}$ & - & - & & - & - & - & - \\
\hline 32 & BR79-63 & $\mathrm{T}$ & 3 & 145.67 & 112.00 & 146 & 145 & 1 & 0.33 \\
\hline 33 & GO 79-1039 & $\mathrm{T}$ & 3 & 148,33 & 114,00 & 152 & 145 & 7 & 12,33 \\
\hline 34 & IAC 80-3006 & $\mathrm{T}$ & 4 & 131,75 & 101.00 & 134 & 125 & 9 & 20.25 \\
\hline 35 & IAC-2 & $\mathrm{T}$ & 4 & 128.25 & 98,00 & 134 & 125 & 9 & 18,25 \\
\hline 36 & Numbaíra & $\mathrm{T}$ & 3 & 142,67 & 110.00 & 148 & 134 & 14 & 57.33 \\
\hline 37 & Paranagoiana & T & 5 & 146,60 & 113,00 & 152 & 144 & 8 & 9,80 \\
\hline 38 & Timbira & $\mathrm{T}$ & 3 & 146,33 & 112.00 & 148 & 145 & 3 & 2.33 \\
\hline 39 & Tropical & $\mathrm{T}$ & 3 & 143.00 & 110,00 & 145 & 140 & 5 & 7.00 \\
\hline 40 & White Biloxi & $\mathrm{T}$ & 2 & 127.50 & 98.00 & 129 & 126 & 3 & 4.50 \\
\hline \multicolumn{3}{|c|}{ Média Geral } & & 130.24 & 100.00 & & & & 24.61 \\
\hline
\end{tabular}

${ }^{a}$ Média aritmética com todos os valores individuais $(\mathrm{i}=1,2 \ldots, \mathrm{n})$;

P. SP. ST e T: precoce, semi-precoce. semi-tardio e tardio. 
Tabela 6 APM: altura da planta na maturidade. Número de plantas (n), média $(\bar{X})$, porcentagem em relação à média geral dos 36 parentais (\%), valores máximo (máx) e mínimo (mín), amplitude $(\operatorname{amp}=$ máx $-\operatorname{mín})$ e variância ambiental média $\left(\hat{\sigma}_{\mathbf{e}}^{2}\right)$. Soja, Piracicaba, transplantio em 21/12/92.

\begin{tabular}{|c|c|c|c|c|c|c|c|c|c|}
\hline \multicolumn{2}{|c|}{ Parentais } & ciclo & \multirow{2}{*}{$\frac{n}{3}$} & \multirow{2}{*}{$\frac{\bar{x}^{a}}{67.33}$} & \multirow{2}{*}{$\frac{\%}{94}$} & \multirow{2}{*}{$\frac{\operatorname{máx}}{75}$} & \multirow{2}{*}{$\frac{\min }{62}$} & \multirow{2}{*}{$\frac{\text { amp. }}{13}$} & \multirow{2}{*}{$\frac{\hat{\sigma}_{\mathbf{e}}^{2}}{46,33}$} \\
\hline 01 & CEPS-7716 & $\bar{P}$ & & & & & & & \\
\hline 02 & Coker-136 & $\mathrm{P}$ & 2 & 59,00 & 82 & 65 & 53 & 12 & 72,00 \\
\hline 03 & Forrest & P & 5 & 43.40 & 61 & 52 & 35 & 17 & 40,30 \\
\hline 04 & FT $81-1835$ & $\mathrm{P}$ & 4 & 37,75 & 53 & 40 & 34 & 6 & 6,92 \\
\hline 05 & FT 81-2134 & $\mathrm{P}$ & - & - & - & - & - & - & - \\
\hline 06 & Hale-321 & $\mathrm{P}$ & 2 & 99,50 & 139 & 112 & 87 & 25 & 312,50 \\
\hline 07 & IAC-Foscarin 31 & $\mathrm{P}$ & - & - & - & - & - & - & - \\
\hline 08 & Paraná & $\mathrm{P}$ & - & - & - & - & - & - & - \\
\hline 09 & Primavera & $\mathrm{P}$ & 4 & 84,00 & 117 & 95 & 80 & 15 & 54.00 \\
\hline 10 & SOC $81-79$ & $\mathrm{P}$ & 2 & 75,00 & 105 & 80 & 70 & 10 & 50,00 \\
\hline 11 & Bossier & SP & 2 & 47,50 & 66 & 50 & 45 & 5 & 12.50 \\
\hline 12 & BR-1 & SP & 2 & 42,50 & 59 & 45 & 40 & 5 & 12,50 \\
\hline 13 & Davis & SP & 3 & 43,00 & 60 & 45 & 40 & 5 & 7,00 \\
\hline 14 & FT $81-2706$ & SP & 4 & 71,50 & 100 & 75 & 65 & 10 & 20,33 \\
\hline 15 & GO 81-11046 & $\mathrm{SP}$ & 3 & 76,67 & 107 & 80 & 75 & 5 & 8,33 \\
\hline 16 & IAC-1 & SP & 4 & 83,00 & 116 & 91 & 76 & 15 & 42,00 \\
\hline 17 & IAC-10 & SP & 3 & 63.67 & 89 & 65 & 63 & 2 & 1,33 \\
\hline 18 & IAC -12 & SP & 3 & 53.33 & 74 & 55 & 50 & 5 & 8,33 \\
\hline 19 & SOC 81-228 & SP & 4 & 60,25 & 84 & 65 & 56 & 9 & 13,58 \\
\hline 20 & Viçoja & $\mathrm{SP}$ & 5 & 42,40 & 59 & 50 & 37 & 13 & 26,30 \\
\hline 21 & Cristalina & ST & 3 & 72,33 & 101 & 75 & 70 & 5 & 6,33 \\
\hline 22 & EMGOPA-301 & ST & 3 & 94,00 & 131 & 98 & 87 & 11 & 37,00 \\
\hline 23 & IAC-11 & ST & 4 & 76.75 & 107 & 82 & 70 & 12 & 28,92 \\
\hline 24 & $\mathrm{IAC}-4$ & ST & 3 & 55,00 & 77 & 55 & 55 & 0 & 0,00 \\
\hline 25 & IAC -5 & ST & 4 & 86,00 & 120 & 95 & 75 & 20 & 84.67 \\
\hline 26 & IAC-6 & ST & 5 & 83,20 & 116 & 95 & 68 & 27 & 106.70 \\
\hline 27 & IAC-8 & ST & 3 & 80,00 & 112 & 85 & 75 & 10 & 25.00 \\
\hline 28 & IAC-9 & ST & 2 & 78,00 & 109 & 84 & 72 & 12 & 72,00 \\
\hline 29 & Santa Rosa & ST & 3 & 71,00 & 99 & 78 & 65 & 13 & 43,00 \\
\hline 30 & SS-1 & ST & 5 & 75,80 & 106 & 80 & 74 & 6 & 5,70 \\
\hline 31 & BR-11 & $\mathrm{T}$ & - & - & - & - & - & - & - \\
\hline 32 & BR79-63 & $\mathrm{T}$ & 3 & 85,00 & 119 & 90 & 80 & 10 & 25.00 \\
\hline 33 & GO 79-1039 & $\mathrm{T}$ & 3 & 81,67 & 114 & 85 & 80 & 5 & 8.33 \\
\hline 34 & IAC 80-3006 & $\mathrm{T}$ & 4 & 66,75 & 93 & 80 & 55 & 25 & 171.58 \\
\hline 35 & IAC-2 & $\mathrm{T}$ & 4 & 100.50 & 140 & 110 & 82 & 28 & 157.67 \\
\hline 36 & Numbaíra & $\mathrm{T}$ & 3 & 71,67 & 100 & 75 & 65 & 10 & 33.33 \\
\hline 37 & Paranagoiana & $T$ & 5 & 79,60 & 111 & 90 & 73 & 17 & 43,30 \\
\hline 38 & Timbira & $\mathrm{T}$ & 3 & 83,67 & 117 & 91 & 75 & 16 & 65,33 \\
\hline 39 & Tropical & $\mathrm{T}$ & 3 & 104,33 & 146 & 106 & 102 & 4 & 4,33 \\
\hline 40) & White Biloxi & $\mathrm{T}$ & 2 & 102.50 & 143 & 110 & 95 & 15 & 112.50 \\
\hline \multicolumn{3}{|c|}{ Média Geral } & & 71.70 & 100 & & & & 46.55 \\
\hline
\end{tabular}

${ }^{a}$ Média aritmética com todos os valores individuais $(\mathrm{i}=1,2 \ldots . \mathrm{n})$ :

P. SP, ST e T: precoce. semi-precoce. semi-tardio e tardio. 
Tabela 7 VA: valor agronômico $(x=1$ a 5). Número de plantas $(n)$, média $(\bar{x})$, porcentagem em relação à média geral dos 36 parentais (\%), valores máximo (máx) e mínimo (mín), amplitude $\left(\operatorname{amp}=\right.$ máx - mín) e variância ambiental média $\left(\hat{\sigma}_{\mathbf{e}}^{2}\right)$. Soja, Piracicaba, transplantio em 21/12/92.

\begin{tabular}{|c|c|c|c|c|c|c|c|c|c|}
\hline \multicolumn{2}{|c|}{ Parentais } & \multirow{2}{*}{$\frac{\text { ciclo }}{\mathrm{P}}$} & \multirow{2}{*}{$\frac{n}{3}$} & \multirow{2}{*}{$\frac{\overline{\mathrm{x}}^{\mathrm{a}}}{3.20}$} & \multirow{2}{*}{$\begin{array}{r}\% \\
102\end{array}$} & \multirow{2}{*}{$\frac{\text { máx }}{3,50}$} & \multirow{2}{*}{$\frac{\min }{3.00}$} & \multirow{2}{*}{$\frac{\text { amp. }}{0,50}$} & \multirow{2}{*}{$\frac{\hat{\sigma}_{\mathbf{e}}^{2}}{0,0056}$} \\
\hline$\overline{1}$ & CEPS-7716 & & & & & & & & \\
\hline 2 & Coker-136 & $\mathrm{P}$ & 2 & 3,30 & 105 & 3,50 & 3,00 & 0,50 & 0,0083 \\
\hline 3 & Forrest & $\mathrm{P}$ & 5 & 2,20 & 71 & 3,00 & 1,50 & 1,50 & 0,0299 \\
\hline 4 & FT 812134 & $\mathrm{P}$ & - & - & - & 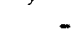 & - & 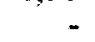 & - \\
\hline 5 & FT $81-1835$ & $\mathrm{P}$ & 4 & 2,40 & 77 & 3,00 & 2,00 & 1,00 & 0.0194 \\
\hline 6 & Hale-321 & $\mathrm{P}$ & 2 & 2,80 & 89 & 3,50 & 2,00 & 1,50 & 0.0877 \\
\hline 7 & IAC Foscarin 31 & $\mathbf{P}$ & - & - & - & - & $=$ & - & - \\
\hline 8 & Paraná & $\mathrm{P}$ & - & - & - & - & - & - & - \\
\hline 9 & Primavera & $\mathrm{P}$ & 4 & 3,40 & 109 & 3,50 & 3,00 & 0,50 & 0.0042 \\
\hline 10 & SOC $81-79$ & $\mathrm{P}$ & 2 & 3,80 & 121 & 4,00 & 3,50 & 0,50 & 0.0074 \\
\hline 11 & Bossier & SP & 2 & 2,50 & 81 & 2,50 & 2,50 & 0,00 & - \\
\hline 12 & BR-1 & SP & 2 & 1.50 & 48 & 1,50 & 1,50 & 0.00 & - \\
\hline 13 & Davis & $\mathrm{SP}$ & 3 & 2.30 & 75 & 3,00 & 2,00 & 1,00 & 0.0280 \\
\hline 14 & FT $81-2706$ & SP & 4 & 3,10 & 101 & 4,00 & 2,50 & 1,50 & 0.0384 \\
\hline 15 & GO 81-11046 & SP & 3 & 3,20 & 102 & 3,50 & 3,00 & 0,50 & 0,0056 \\
\hline 16 & IAC-1 & SP & 4 & 2.80 & 89 & 3,50 & 2,00 & 1,50 & 0.0325 \\
\hline 17 & IAC-10 & SP & 3 & 3,50 & 113 & 4,00 & 3,00 & 1,00 & 0.0157 \\
\hline 18 & IAC-12 & $\mathrm{SP}$ & 3 & 2,70 & 86 & 3,00 & 2,50 & 0,50 & 0.0064 \\
\hline 19 & SOC 81-228 & SP & 4 & 2,80 & 89 & 3,00 & 2,50 & 0,50 & 0,0064 \\
\hline 20 & Viçoja & SP & 5 & 2,20 & 71 & 2,50 & 1,50 & 1,00 & 0.0200 \\
\hline 21 & Cristalina & ST & 3 & 3,20 & 102 & 3,50 & 3,00 & 0,50 & 0,0056 \\
\hline 22 & EMGOPA-301 & ST & 3 & 3.80 & 124 & 4,00 & 3,50 & 0.50 & 0.0049 \\
\hline 23 & IAC-11 & ST & 4 & 3,30 & 105 & 3,50 & 3,00 & 0,50 & 0.0056 \\
\hline 24 & IAC-4 & ST & 3 & 2.70 & 86 & 3,00 & 2,50 & 0.50 & 0.0064 \\
\hline 25 & IAC-5 & ST & 4 & 3,40 & 109 & 4,00 & 3,00 & 1,00 & 0.0145 \\
\hline 26 & IAC-6 & ST & 5 & 3.70 & 119 & 4,50 & 3,00 & 1.50 & 0.0192 \\
\hline 27 & IAC- 8 & ST & 3 & 4.20 & 134 & 5,00 & 3,50 & 1,50 & 0.0307 \\
\hline 28 & IAC-9 & ST & 2 & 3.30 & 105 & 3,50 & 3.00 & 0.50 & 0.0083 \\
\hline 29 & Santa Rosa & ST & 3 & 3,20 & 102 & 3,50 & 3,00 & 0,50 & 0.0056 \\
\hline 30 & SS-1 & ST & 5 & 3.20 & 103 & 3,50 & 3,00 & 0.50 & 0.0050 \\
\hline 31 & BR-11 & $\mathrm{T}$ & & - & - & - & - & - & - \\
\hline 32 & BR79-63 & $\mathrm{T}$ & 3 & 3.30 & 108 & 4.00 & 2.50 & 1.50 & 0.0397 \\
\hline 33 & GO 79-1039 & $\mathrm{T}$ & 3 & 3,50 & 113 & 4,00 & 3,00 & 1,00 & 0.0157 \\
\hline 34 & IAC 80-3006 & $\mathrm{T}$ & 4 & 3.40 & 109 & 4,00 & 2.50 & 1,50 & 0.0042 \\
\hline 35 & IAC -2 & $\mathrm{~T}$ & 4 & 3,10 & 101 & 3,50 & 3.00 & 0,50 & 0.0270 \\
\hline 36 & Numbaíra & $\mathrm{T}$ & 3 & 3.00 & 97 & 3.00 & 3,00 & 0.00 & 0.0000 \\
\hline 37 & Paranagoiana & $\mathrm{T}$ & 5 & 3,50 & 113 & 4,00 & 3,00 & 1,00 & 0.0078 \\
\hline 38 & Timbira & $\mathrm{T}$ & 3 & 3.30 & 108 & 4,00 & 3,00 & 1,00 & 0.0209 \\
\hline 39 & Tropical & $\mathrm{T}$ & 3 & 3,50 & 113 & 4,00 & 3,00 & 1.00 & 0.0157 \\
\hline 40 & White Biloxi & $\hat{T}$ & 2 & 4.30 & 137 & 4.50 & 4.00 & 0.50 & 0.0066 \\
\hline \multicolumn{3}{|c|}{ Média Geral } & & 3.10 & 100 & & & & 0.0157 \\
\hline
\end{tabular}

${ }^{a}$ Média aritmética com todos os valores individuais $(i=1,2 \ldots . n)$ :

P. SP. ST e T: precoce. semi-precoce. semi-tardio e tardio. 
Tabela 8 PG: produtividade de grãos (g/planta). Número de plantas (n), média $(\overline{\mathrm{X}})$, porcentagem em relação à média geral dos 36 parentais (\%), valores máximo (máx) e mínimo (mín), amplitude (amp. $=$ máx - mín) e variância ambiental média $\left(\hat{\sigma}_{\mathbf{e}}^{2}\right)$. Soja, Piracicaba, transplantio em 21/12/92.

\begin{tabular}{|c|c|c|c|c|c|c|c|c|c|}
\hline \multicolumn{2}{|c|}{ Parentais } & \multirow{2}{*}{$\frac{\text { ciclo }}{\mathrm{P}}$} & \multirow{2}{*}{$\frac{n}{3}$} & \multirow{2}{*}{$\frac{\bar{x}^{a}}{50.04}$} & \multirow{2}{*}{$\frac{\%}{63}$} & \multirow{2}{*}{$\frac{\text { máx }}{54.32}$} & \multirow{2}{*}{$\frac{\text { mín }}{47.77}$} & \multirow{2}{*}{$\frac{\text { amp. }}{6.55}$} & \multirow{2}{*}{$\frac{\hat{\sigma}_{\mathbf{e}}^{2}}{13,76}$} \\
\hline$\overline{1}$ & CEPS-7716 & & & & & & & & \\
\hline 2 & Coker-136 & $\mathrm{P}$ & 2 & 47,11 & 59 & 57,12 & 37,10 & 20,02 & 200,40 \\
\hline 3 & Forrest & $\mathrm{P}$ & 5 & 28,04 & 35 & 37,21 & 20,13 & 17,08 & 43,78 \\
\hline 4 & FT $81-1835$ & $\mathrm{P}$ & 4 & 58,50 & 74 & 66,14 & 48,00 & 18,14 & 59,47 \\
\hline 5 & FT $81-2134$ & $\mathrm{P}$ & - & - & - & - & - & - & - \\
\hline 6 & Hale-321 & $\mathrm{P}$ & 2 & 67,68 & 85 & 70,37 & 64,98 & 5,39 & 14,53 \\
\hline 7 & IAC-Foscarin 31 & $\mathrm{P}$ & - & - & - & 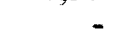 & - & 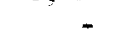 & - \\
\hline 8 & Paraná & $\mathrm{P}$ & - & - & - & - & - & - & - \\
\hline 9 & Primavera & $\mathrm{P}$ & 4 & 53,93 & 68 & 69,56 & 37,59 & 31.97 & 173,25 \\
\hline 10 & SOC $81-79$ & $\mathrm{P}$ & 2 & 64,94 & 82 & 81,85 & 48,03 & 33.82 & 571,90 \\
\hline 11 & Bossier & SP & 2 & 61,47 & 77 & 70,92 & 52,01 & 18,91 & 178,79 \\
\hline 12 & BR-1 & SP & 2 & 44.19 & 56 & 53,20 & 35,17 & 18.03 & 162.54 \\
\hline 13 & Davis & SP & 3 & 34,98 & 44 & 38,99 & 29,25 & 9.74 & 25,95 \\
\hline 14 & FT 81-2706 & $\mathrm{SP}$ & 4 & 76,13 & 96 & 99,30 & 46,48 & 52.82 & 623,83 \\
\hline 15 & GO 81-11046 & SP & 3 & 54,30 & 68 & 56,28 & 53,21 & 3,07 & 2,95 \\
\hline 16 & IAC - 1 & $\mathrm{SP}$ & 4 & 82,16 & 103 & 99,99 & 70,05 & 29,94 & 160,79 \\
\hline 17 & IAC- 10 & SP & 3 & 87,56 & 110 & 96,08 & 74,83 & 21,25 & 126,23 \\
\hline 18 & IAC-12 & SP & 3 & 72.61 & 91 & 100,50 & 51,26 & 49,21 & 637,19 \\
\hline 19 & SOC $81-228$ & SP & 4 & 46,30 & 58 & 54,76 & 32,25 & 22,51 & 95,29 \\
\hline 20 & Viçoja & $\mathrm{SP}$ & 5 & 66,46 & 84 & 71,53 & 59,80 & 11,73 & 18,67 \\
\hline 21 & Cristalina & ST & 3 & 78,66 & 99 & 109,90 & 62.31 & 47,59 & 732,49 \\
\hline 22 & EMGOPA-301 & ST & 3 & 118,50 & 149 & 139,20 & 104,10 & 35,11 & 337,29 \\
\hline 23 & IAC-11 & ST & 4 & 99.21 & 125 & 119,70 & 57,45 & 62,20 & 806,47 \\
\hline 24 & IAC-4 & ST & 3 & 86,65 & 109 & 94,34 & 80,38 & 13.96 & 50.25 \\
\hline 25 & IAC-5 & ST & 4 & 72,25 & 91 & 87,72 & 53,16 & 34,56 & 226,83 \\
\hline 26 & IAC-6 & ST & 5 & 117,10 & 147 & 164,50 & 98.63 & 65.83 & 741,50 \\
\hline 27 & IAC- 8 & ST & 3 & 103.00 & 130 & 115,70 & 92.66 & 23.08 & 137,66 \\
\hline 28 & IAC-9 & ST & 2 & 108,80 & 137 & 114.70 & 102.90 & 11.84 & 70.09 \\
\hline 29 & Santa Rosa & ST & 3 & 89.88 & 113 & 109,10 & 76,93 & 32.15 & 287.70 \\
\hline 30 & SS-1 & ST & 5 & 96,15 & 121 & 122,10 & 77,05 & 45.00 & 296,67 \\
\hline 31 & BR-11 & $\mathrm{T}$ & - & - & - & $=$ & - & - & - \\
\hline 32 & BR79-63 & $\mathrm{T}$ & 3 & 90,57 & 114 & 112,20 & 63,04 & 49.18 & 630.66 \\
\hline 33 & GO 79-1039 & $\mathrm{T}$ & 3 & 93.48 & 118 & 104,60 & 79,45 & 25.12 & 164,24 \\
\hline 34 & IAC 80-3006 & $\mathrm{T}$ & 4 & 95,10 & 120 & 108,90 & 82,11 & 26,75 & 171,20 \\
\hline 35 & IAC-2 & $\mathrm{T}$ & 4 & 62,56 & 79 & 70,62 & 48,49 & 22.13 & 101.71 \\
\hline 36 & Numbaíra & $\mathrm{T}$ & 3 & 74,74 & 94 & 97,25 & 56.80 & 40.45 & 424.67 \\
\hline 37 & Paranagoiana & $\mathrm{T}$ & 5 & 130.90 & 165 & 162.00 & 99,39 & 62.64 & 504,42 \\
\hline 8 & Timbira & $\mathrm{T}$ & 3 & 128.40 & 162 & 145,50 & 99.06 & 46.39 & 652.28 \\
\hline 39 & Tropical & $\mathrm{T}$ & 3 & 91.68 & 115 & 114,00 & 60.03 & 53.93 & 792,87 \\
\hline 40 & White Biloxi & $\mathrm{T}$ & 2 & 98.46 & 124 & 105.70 & 91.26 & 14.39 & 103.54 \\
\hline \multicolumn{3}{|c|}{ Média Geral } & & 79.40 & 100 & & & & 297.80 \\
\hline
\end{tabular}

${ }^{a}$ Média aritmética com todos os valores individuais $(\mathrm{i}=1,2 \ldots, \mathrm{n})$;

P, SP. ST e T: precoce, semi-precoce, semi-tardio e tardio. 


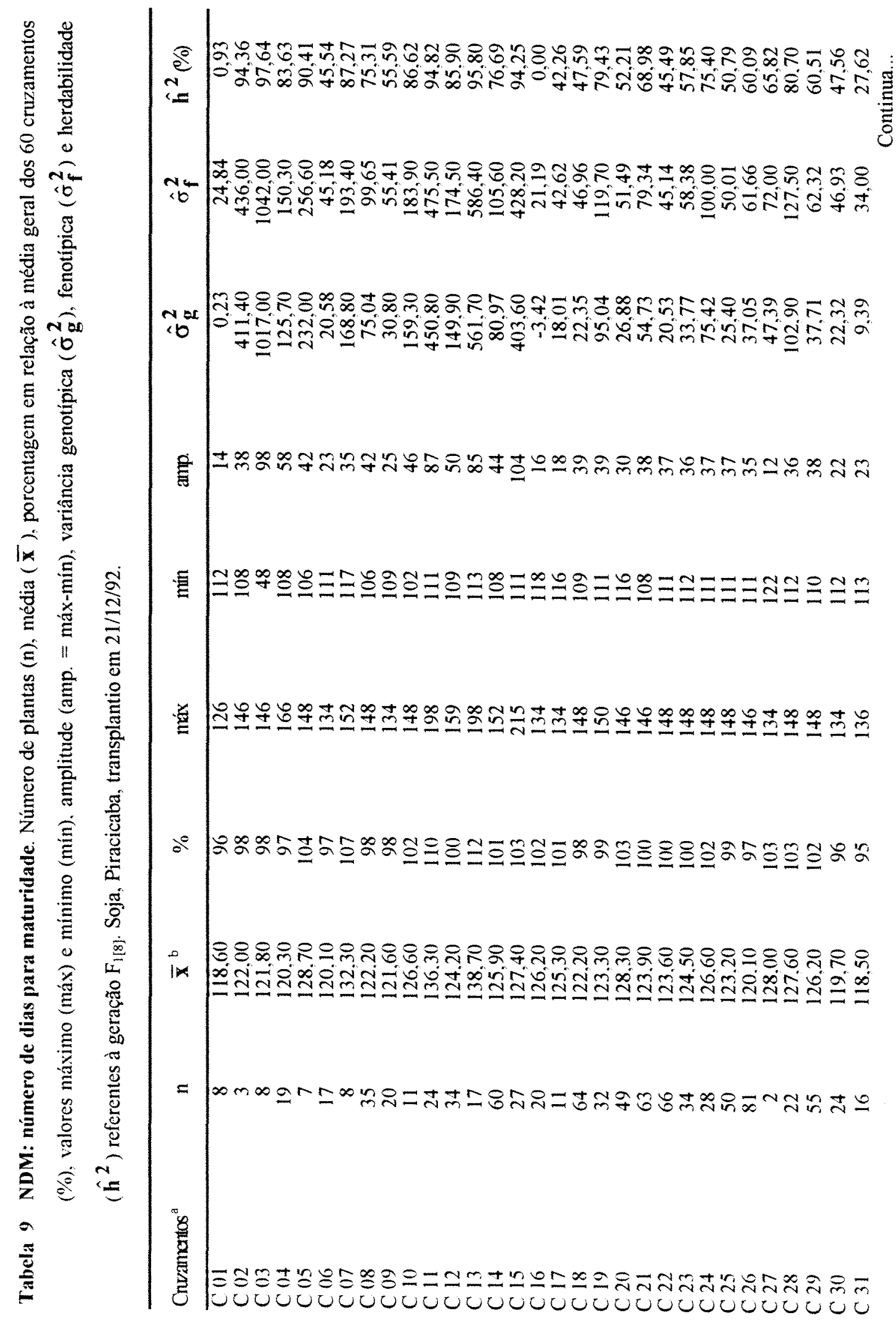




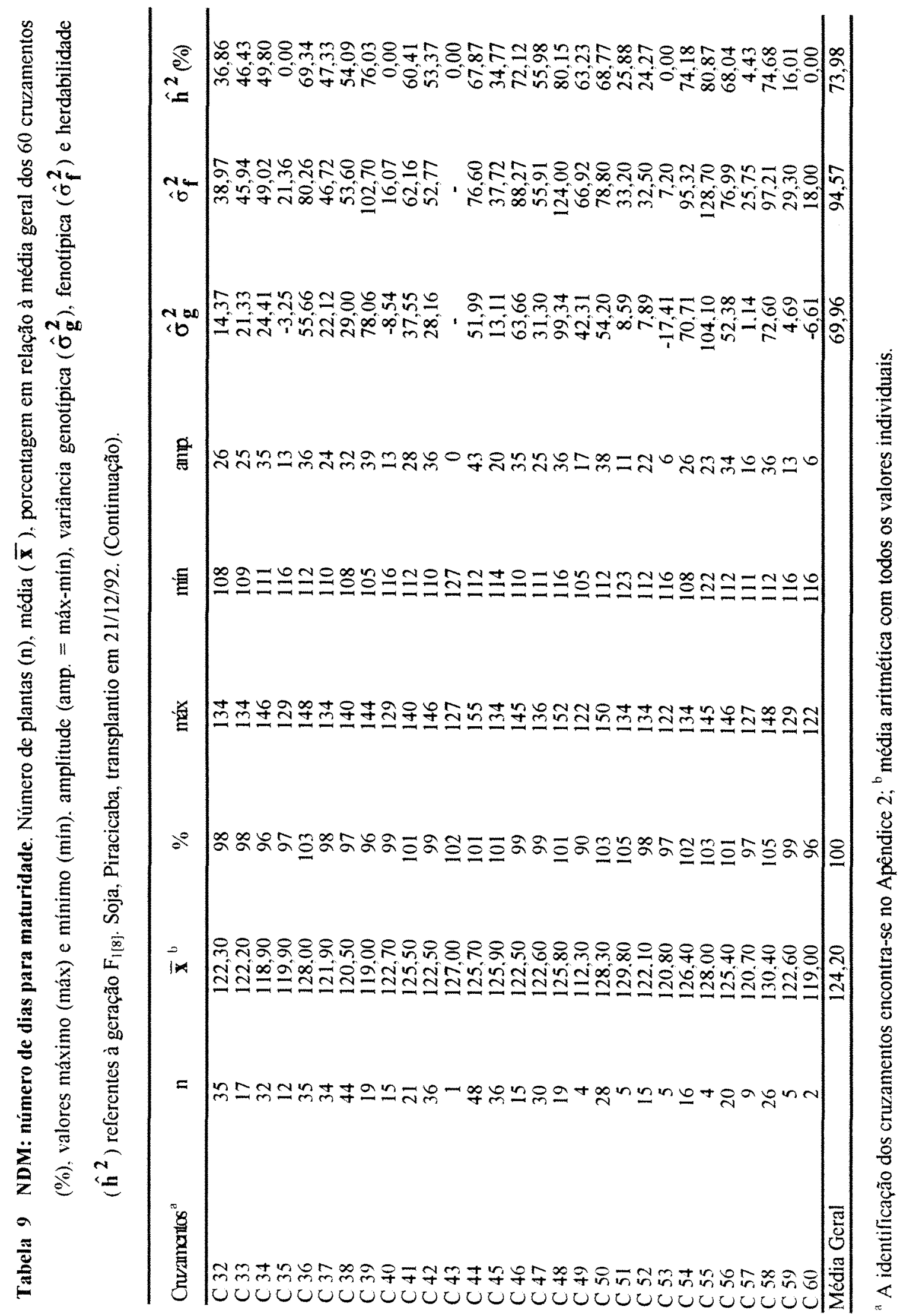


Tabela 10 NDM: número de dias para a maturidade. Maiores e menores coeficientes de herdabilidade, dos cruzamentos com número de plantas $(\mathrm{n})$ igual ou superior a 15 , referentes à geração $F_{1[8]}$. Soja, Piracicaba, transplantio em 21/12/92.

\begin{tabular}{lccccc}
\hline \multicolumn{2}{c}{ Maiores herdabilidades } & \multicolumn{3}{c}{ Menores herdabilidades } \\
\hline Cruzamentos & $\mathrm{n}$ & $\hat{\mathbf{h}}^{\mathbf{2}}$ & Cruzamentos & $\mathrm{n}$ & $\hat{\mathbf{h}}^{\mathbf{2}}$ \\
\hline C 13 & 17 & 95,80 & C 38 & 44 & 54,09 \\
C 11 & 24 & 94,82 & C 42 & 36 & 53,37 \\
C 15 & 27 & 94,25 & C 20 & 49 & 52,21 \\
C 12 & 34 & 85,90 & C 25 & 50 & 50,79 \\
C 04 & 19 & 83,63 & C 34 & 32 & 49,80 \\
C 28 & 22 & 80,70 & C 18 & 64 & 47,59 \\
C 48 & 19 & 80,15 & C 30 & 24 & 47,56 \\
C 19 & 32 & 79,43 & C 37 & 34 & 47,33 \\
C 14 & 60 & 76,69 & C 33 & 17 & 46,43 \\
C 39 & 19 & 76,03 & C 06 & 17 & 45,54 \\
C 24 & 28 & 75,40 & C 22 & 66 & 45,49 \\
C 08 & 35 & 75,31 & C 32 & 35 & 36,86 \\
C 58 & 26 & 74,68 & C 45 & 36 & 34,77 \\
C 54 & 16 & 74,18 & C 31 & 16 & 27,62 \\
C 46 & 15 & 72,12 & C 52 & 15 & 24,27 \\
\hline
\end{tabular}

${ }^{a}$ A identificação dos cruzamentos encontra-se no Apêndice 2 


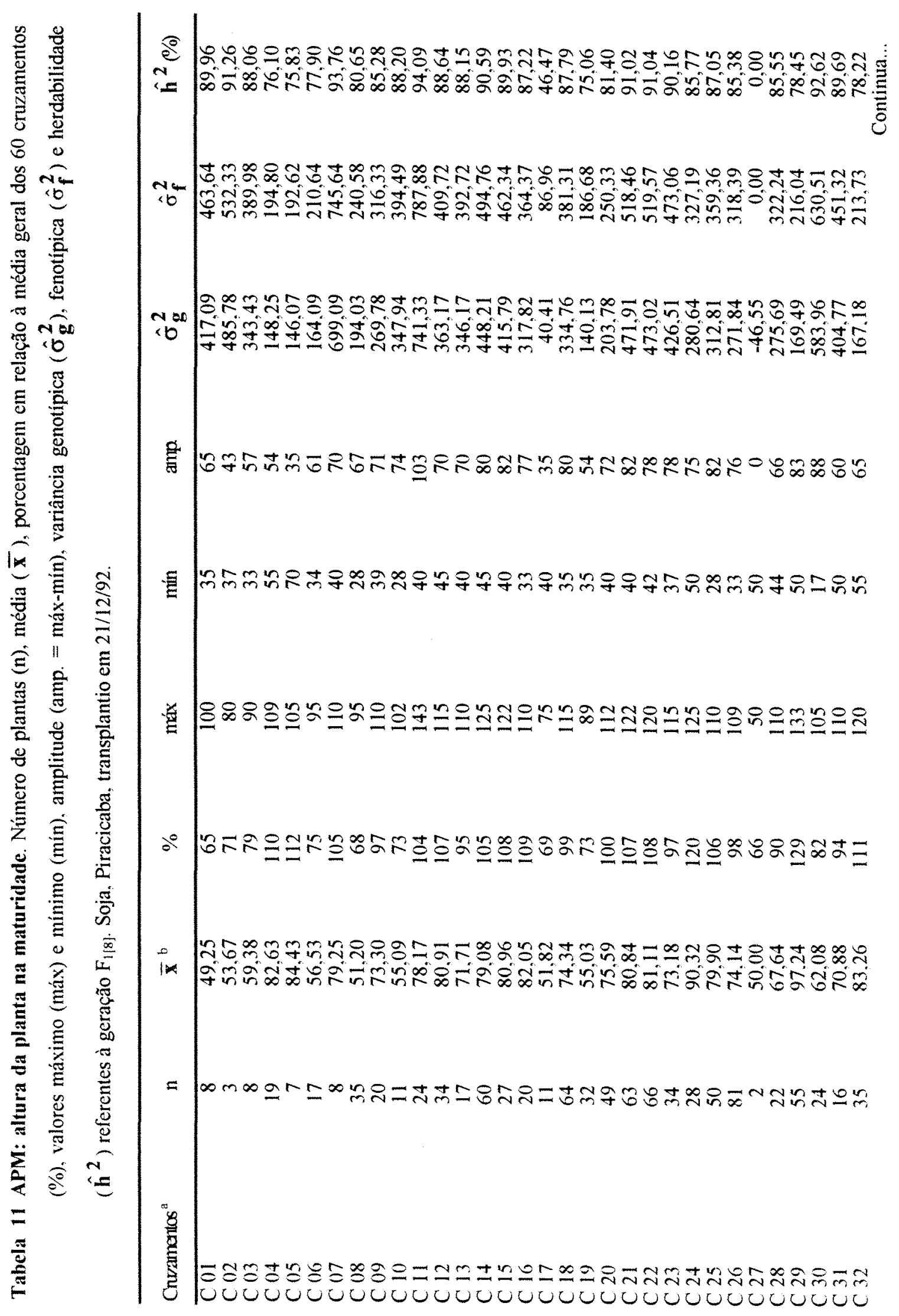




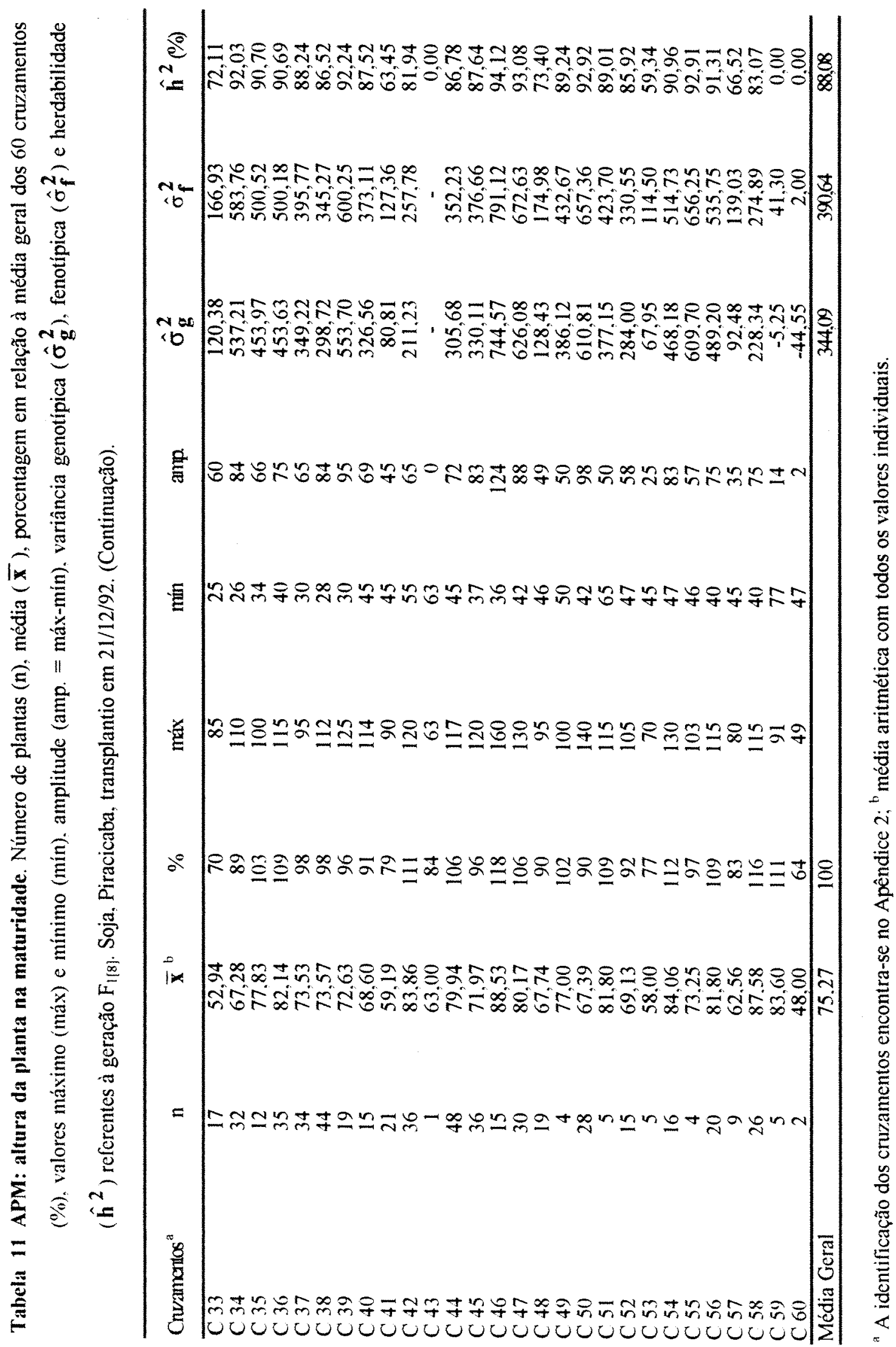


Tabela 12 APM: altura da planta na maturidade. Maiores e menores coeficientes de herdabilidade, dos cruzamentos com número de plantas (n) igual ou superior a 15 , referentes à geração $\mathrm{F}_{1[8]}$. Soja, Piracicaba, transplantio em 21/12/92.

\begin{tabular}{lccccc}
\hline \multicolumn{2}{c}{ Maiores herdabilidades } & \multicolumn{3}{c}{ Menores herdabilidades } \\
\hline Cruzamentos & $\mathbf{n}$ & $\hat{\mathbf{h}}^{\mathbf{2}}$ & Cruzamentos & $\mathrm{n}$ & $\hat{\mathbf{h}}^{\mathbf{2}}$ \\
\hline C 46 & 15 & 94,12 & C 28 & 22 & 85,55 \\
C 11 & 24 & 94,09 & C 26 & 81 & 85,38 \\
C 47 & 30 & 93,08 & C 09 & 20 & 85,28 \\
C 50 & 28 & 92,92 & C 58 & 26 & 83,07 \\
C 30 & 24 & 92,62 & C 42 & 36 & 81,94 \\
C 39 & 19 & 92,24 & C 20 & 49 & 81,40 \\
C 34 & 32 & 92,03 & C 08 & 35 & 80,65 \\
C 56 & 20 & 91,31 & C 29 & 55 & 78,45 \\
C 22 & 66 & 91,04 & C 32 & 35 & 78,22 \\
C 21 & 63 & 91,02 & C 06 & 17 & 77,90 \\
C 54 & 16 & 90,96 & C 04 & 19 & 76,10 \\
C 36 & 35 & 90,69 & C 19 & 32 & 75,06 \\
C 14 & 60 & 90,59 & C 48 & 19 & 73,40 \\
C 23 & 34 & 90,16 & C 33 & 17 & 72,11 \\
C 15 & 27 & 89,93 & C 41 & 21 & 63,45 \\
\hline
\end{tabular}

${ }^{a}$ A identificação dos cruzamentos encontra-se no Apêndice 2 


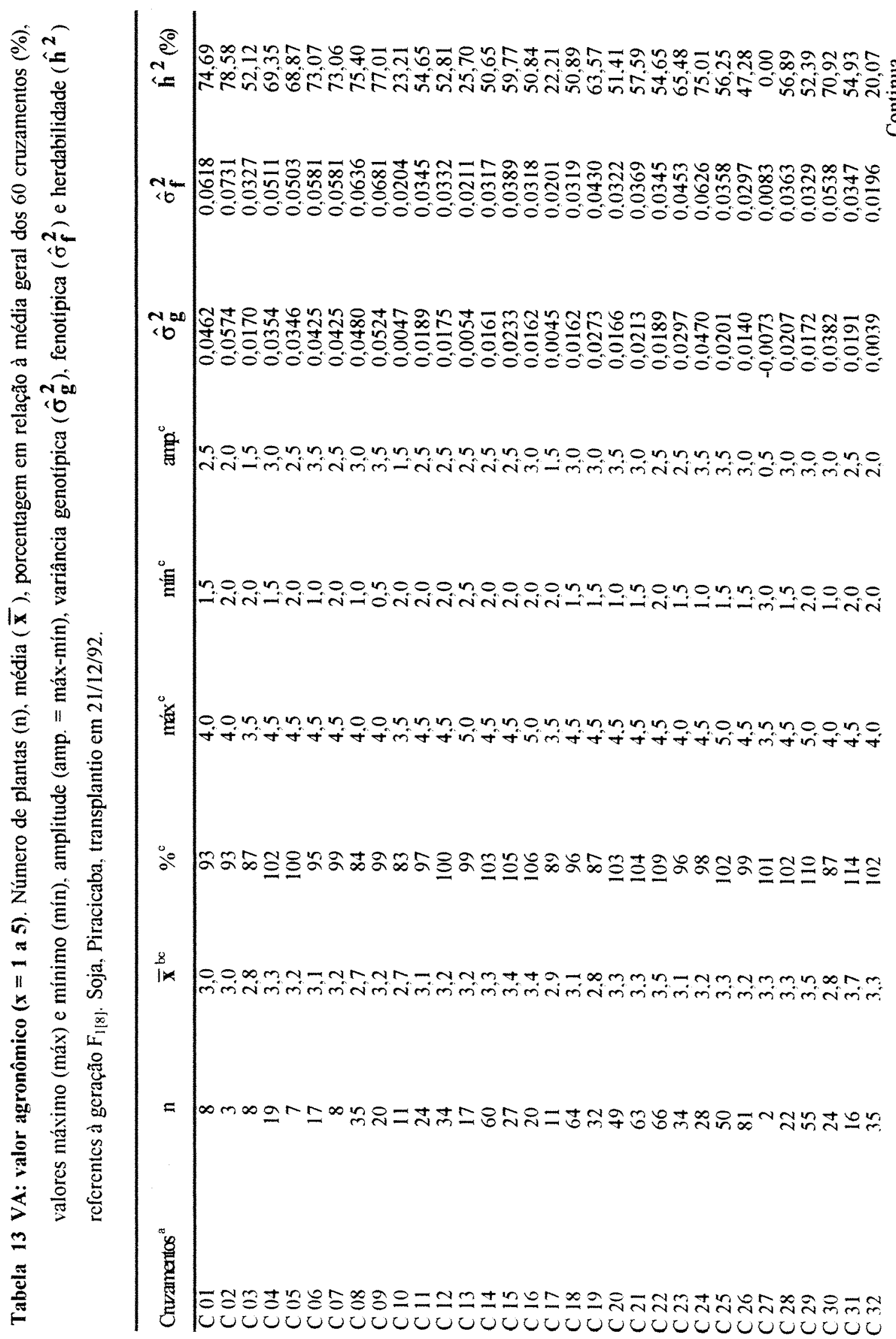




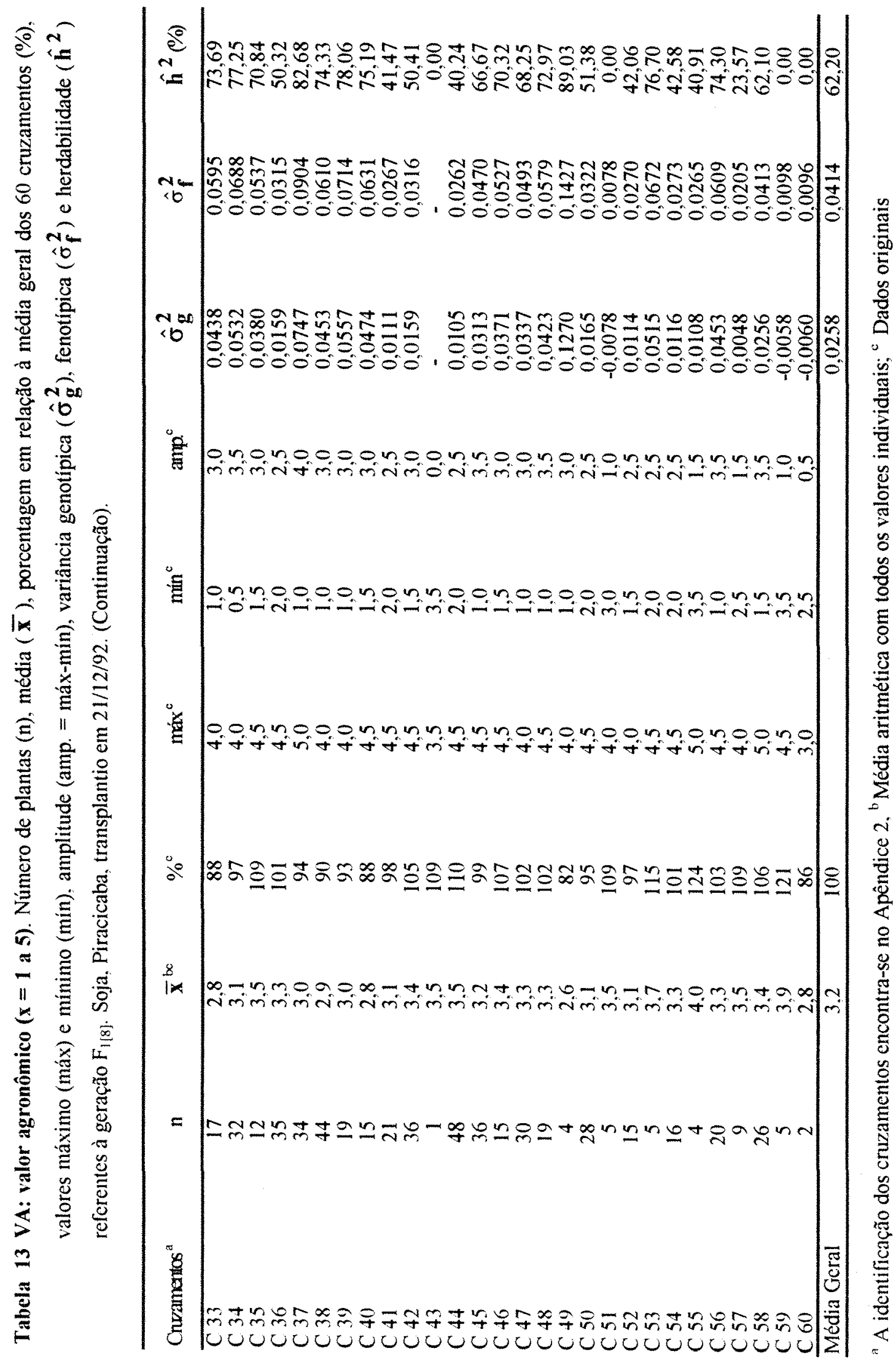


Tabela 14 VA: valor agronômico $(x=1$ a 5$)$. Maiores e menores coeficientes de herdabilidade, dos cruzamentos com número de plantas (n) igual ou superior a 15 , referentes à geração $F_{1[8]}$. Soja, Piracicaba, transplantio em 21/12/92.

\begin{tabular}{lccccc}
\hline \multicolumn{2}{c}{ Maiores herdabilidades } & \multicolumn{3}{c}{ Menores herdabilidades } \\
\hline Cruzamentos & $\mathrm{n}$ & $\hat{\mathbf{h}}^{\mathbf{2}}$ & Cruzamentos & $\mathrm{n}$ & $\hat{\mathbf{h}}^{\mathbf{2}}$ \\
\hline C 37 & 34 & 82,68 & C 29 & 55 & 52,39 \\
C 39 & 19 & 78,06 & C 20 & 49 & 51,41 \\
C 34 & 32 & 77,25 & C 50 & 28 & 51,38 \\
C 09 & 20 & 77,01 & C 18 & 64 & 50,89 \\
C 08 & 35 & 75,40 & C 16 & 20 & 50,84 \\
C 40 & 15 & 75,19 & C 14 & 60 & 50,65 \\
C 24 & 28 & 75,01 & C 42 & 36 & 50,41 \\
C 38 & 44 & 74,33 & C 36 & 35 & 50,32 \\
C 56 & 20 & 74,30 & C 26 & 81 & 47,28 \\
C 33 & 17 & 73,69 & C 54 & 16 & 42,58 \\
C 06 & 17 & 73,07 & C 52 & 15 & 42,06 \\
C 48 & 19 & 72,97 & C 41 & 21 & 41,47 \\
C 30 & 24 & 70,92 & C 44 & 48 & 40,24 \\
C 46 & 15 & 70,32 & C 13 & 17 & 25,70 \\
C 04 & 19 & 69,35 & C 32 & 35 & 20,07 \\
\hline
\end{tabular}

${ }^{a}$ A identificação dos cruzamentos encontra-se no Apêndice 2 


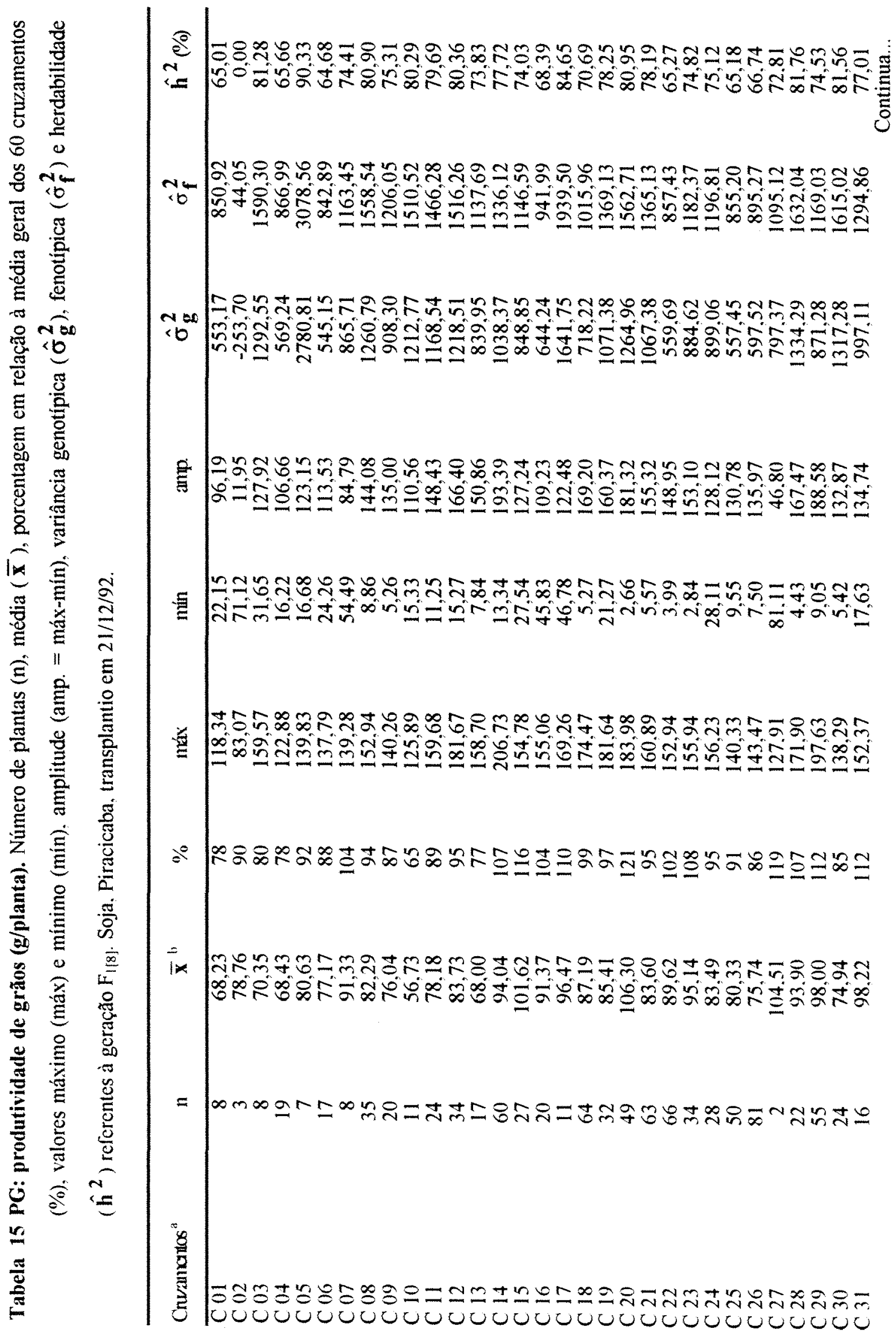




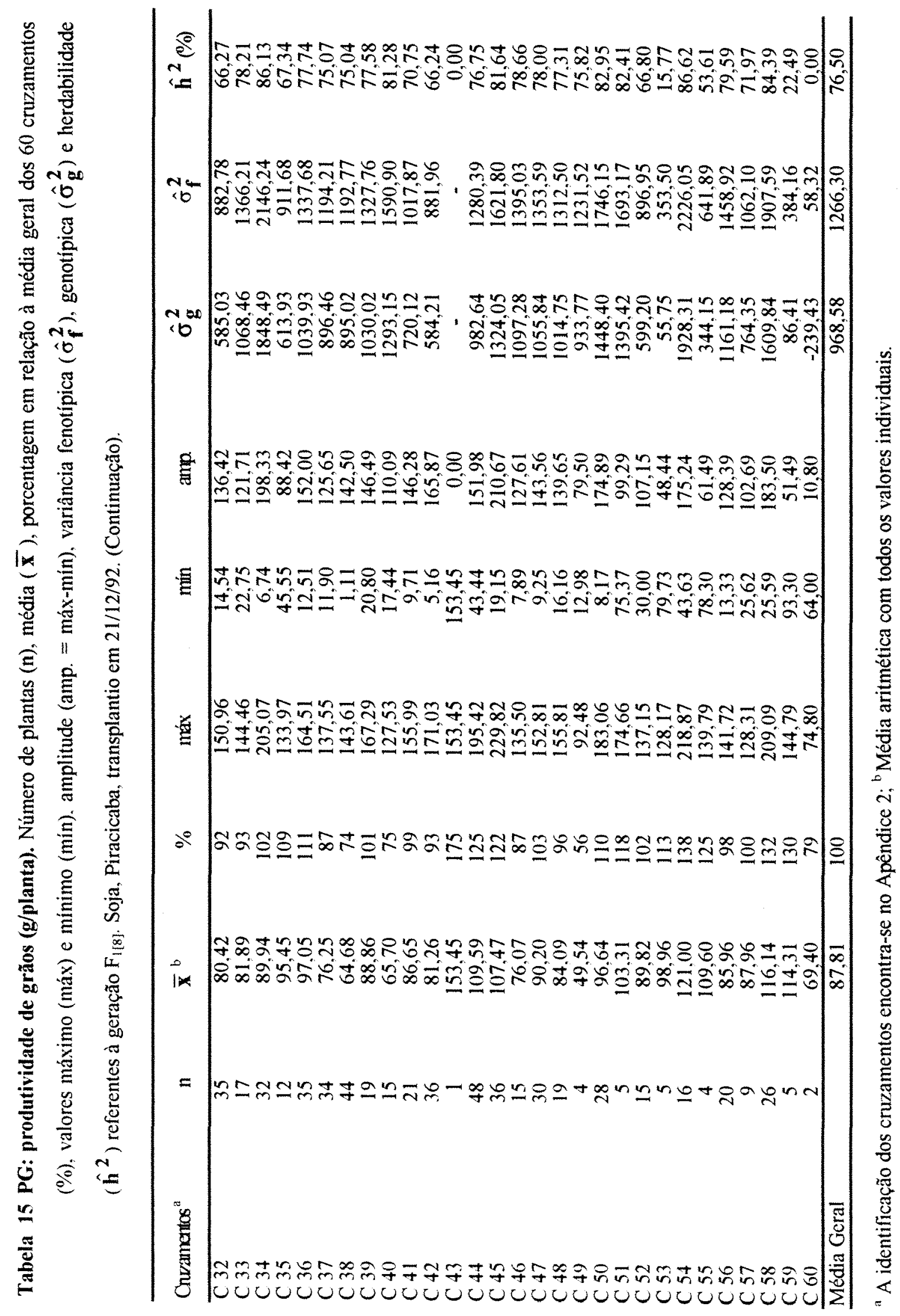


Tabela 16 PG: produtividade de grãos (g/planta). Maiores e menores coeficientes de herdabilidade, dos cruzamentos com número de plantas (n) igual ou superior a 15 , referentes à geração $\mathrm{F}_{1[8]}$. Soja, Piracicaba, transplantio em 21/12/92.

\begin{tabular}{lccccc}
\hline \multicolumn{3}{c}{ Maiores herdabilidades } & \multicolumn{3}{c}{ Menores herdabilidades } \\
\hline Cruzamentos & $\mathrm{n}$ & $\hat{\mathbf{h}}^{2}$ & Cruzamentos & $\mathrm{n}$ & $\hat{\mathbf{h}}^{\mathbf{2}}$ \\
\hline C 54 & 16 & 86,62 & C 29 & 55 & 74,53 \\
C 34 & 32 & 86,13 & C 15 & 27 & 74,03 \\
C 58 & 26 & 84,39 & C 13 & 17 & 73,83 \\
C 50 & 28 & 82,95 & C 41 & 21 & 70,75 \\
C 28 & 22 & 81,76 & C 18 & 64 & 70,69 \\
C 45 & 36 & 81,64 & C 16 & 20 & 68,39 \\
C 30 & 24 & 81,56 & C 35 & 12 & 67,34 \\
C 40 & 15 & 81,28 & C 52 & 15 & 66,80 \\
C 20 & 49 & 80,95 & C 26 & 81 & 66,74 \\
C 08 & 35 & 80,90 & C 32 & 35 & 66,27 \\
C 12 & 34 & 80,36 & C 42 & 36 & 66,24 \\
C 11 & 24 & 79,69 & C 04 & 19 & 65,66 \\
C 56 & 20 & 79,59 & C 22 & 66 & 65,27 \\
C 46 & 15 & 78,66 & C 25 & 50 & 65,18 \\
C 19 & 32 & 78,25 & C 06 & 17 & 64,68 \\
\hline
\end{tabular}

${ }^{\text {a }}$ A identificação dos cruzamentos encontra-se no Apêndice 2 
Tabela 17 Heterose dos 60 cruzamentos para os caracteres número de dias para maturidade (NDM), altura de planta na maturidade (APM), valor agronômico (VA) e produtividade de grãos $(P G)$ referentes à geração

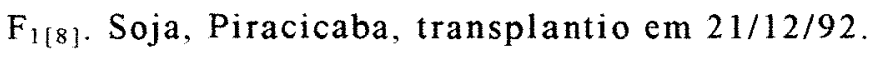

\begin{tabular}{|c|c|c|c|c|}
\hline \multicolumn{5}{|c|}{ Heterose $(\%)$} \\
\hline Cruzamentos ${ }^{\mathrm{a}}$ & NDM & APM & $\mathrm{VA}^{\mathrm{b}}$ & $\mathrm{PG}$ \\
\hline $\mathrm{C} 01$ & $-9,43$ & $-35,39$ & $-4,26$ & 8,16 \\
\hline C 02 & $-6,20$ & $-15,15$ & 0,56 & 0,79 \\
\hline C 03 & $-6,63$ & $-0,31$ & 1,20 & 8,21 \\
\hline C 04 & $-8,49$ & 25,93 & 13,14 & $-16,89$ \\
\hline C 05 & $-0,21$ & 18,52 & 0,52 & 5,05 \\
\hline C 06 & $-7,62$ & $-24,70$ & 4,49 & 13,16 \\
\hline C 07 & 3,61 & 10,90 & $-3,03$ & 15,37 \\
\hline С 08 & $-11,07$ & $-27,40$ & $-14,86$ & 0,37 \\
\hline C 09 & $-6,04$ & $-8,48$ & $-3,86$ & $-2,67$ \\
\hline C 10 & $-4,56$ & $-22,43$ & $-15,25$ & $-34,41$ \\
\hline C 11 & 2,84 & 8,45 & $-0,46$ & $-2,01$ \\
\hline C 12 & -7.64 & 23,16 & 11,44 & $-0,06$ \\
\hline C 13 & 5,34 & $-6,80$ & $-3,45$ & $-22,91$ \\
\hline C 14 & -5.47 & 3,07 & 0,87 & 16,85 \\
\hline C 15 & $-2,80$ & 7,08 & 4,08 & 19,25 \\
\hline C 16 & $-0,55$ & 14,71 & 7,09 & 28,24 \\
\hline C 17 & $-3,43$ & $-18,50$ & $-4,92$ & 22,78 \\
\hline C 18 & $-5,71$ & 15,22 & 3,77 & 19,93 \\
\hline C 19 & $-5,86$ & $-5,48$ & 1,82 & 10,43 \\
\hline C 20 & -2.70 & 8,46 & 3,59 & 31,83 \\
\hline C 21 & -2.87 & 0,37 & $-4,69$ & 3,91 \\
\hline C 22 & -3.79 & 12,74 & 13,36 & 29,10 \\
\hline C 23 & -3.49 & $-5,02$ & $-3,88$ & 10,99 \\
\hline C 24 & -0.45 & 11,15 & $-6,57$ & 2,39 \\
\hline C 25 & -4.50 & $-6,07$ & 0,38 & 6.81 \\
\hline C 26 & -5.53 & $-4,03$ & $-2,18$ & $-2,36$ \\
\hline C 27 & -0.35 & $-31,56$ & 1,15 & 33,53 \\
\hline C 28 & -1.86 & $-0,57$ & 7,32 & 10,37 \\
\hline C 29 & $-1,13$ & 25,79 & 1,82 & 14,43 \\
\hline C 30 & -7.61 & $-23,46$ & $-15,15$ & $-5,51$ \\
\hline C 31 & $-7,21$ & $-2,55$ & 12,61 & 19,41 \\
\hline C 32 & $-4,89$ & 11,37 & 0,38 & $-6,89$ \\
\hline C 33 & -6.59 & $-28,79$ & $-10,04$ & $-2,64$ \\
\hline C 34 & $-10,76$ & 0,26 & 4,64 & 9,86 \\
\hline C 35 & -8.14 & 1,32 & 12,45 & 17,70 \\
\hline C 36 & -0.65 & 23,26 & 17,86 & 38.29 \\
\hline C 37 & -6.42 & $-7,82$ & $-6,61$ & $-3,96$ \\
\hline C 38 & -5.18 & 3,59 & $-5,14$ & -22.25 \\
\hline C 39 & -4.60 & $-7,64$ & -3.23 & 21.50 \\
\hline C 40 & -5.29 & 3,81 & -2.89 & $-18,21$ \\
\hline C 41 & -3.29 & -14.59 & 1.64 & 17.00 \\
\hline C 42 & -4.26 & 31.50 & 23.96 & 25.68 \\
\hline C 43 & -5.16 & -18.91 & 11.36 & 72.07 \\
\hline
\end{tabular}


Tabela 17 Heterose dos 60 cruzamentos para os caracteres número de dias para maturidade (NDM), altura de planta na maturidade (APM), produtividade de grãos (PG) e valor agronômico (VA) referentes à

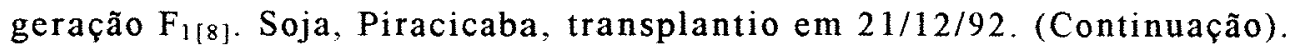

\begin{tabular}{|c|c|c|c|c|}
\hline \multicolumn{5}{|c|}{ Heterose $(\%)$} \\
\hline Cruzamentos $^{\mathrm{a}}$ & NDM & APM & $\mathrm{VA}$ & $\mathrm{PG}$ \\
\hline C 44 & $-2,34$ & 13,09 & 12,45 & 27,08 \\
\hline C 45 & $-2,45$ & $-0,79$ & $-0,39$ & 37,38 \\
\hline C 46 & $-4,18$ & 16,18 & 6,67 & 2,58 \\
\hline C 47 & $-3,19$ & 2,53 & $-3,65$ & 14,15 \\
\hline C 48 & $-0,74$ & $-3,31$ & 7,32 & 12,19 \\
\hline C 49 & $-13,43$ & 16,61 & $-10,86$ & $-35,74$ \\
\hline C 50 & $-0,96$ & 3,87 & 0,81 & 26,83 \\
\hline C 51 & 0,39 & 19,95 & 19,15 & 43,63 \\
\hline C 52 & $-5,23$ & $-1,08$ & 4,20 & 20,86 \\
\hline C 53 & $-9,68$ & $-18,12$ & 21,31 & 16,90 \\
\hline C 54 & $-0,91$ & 17,30 & 7,44 & 59,44 \\
\hline C 55 & $-0,91$ & $-6,13$ & 28,51 & 37,02 \\
\hline C 56 & $-4,02$ & 21,85 & 7,76 & 7,25 \\
\hline C 57 & $-7,01$ & $-5,66$ & 17,32 & 23,29 \\
\hline C 58 & $-1,08$ & 17,82 & 4,08 & 57,67 \\
\hline C 59 & $-5,66$ & 29,94 & 33,71 & 47,02 \\
\hline C 60 & $-6,73$ & $-40,88$ & $-10,91$ & $-11,41$ \\
\hline Média & $-4,24$ & 0,47 & 3,27 & 12,98 \\
\hline
\end{tabular}

${ }^{a}$ A identificação dos cruzamentos encontra-se no Apêndice 2

${ }^{b}$ Dados originais 


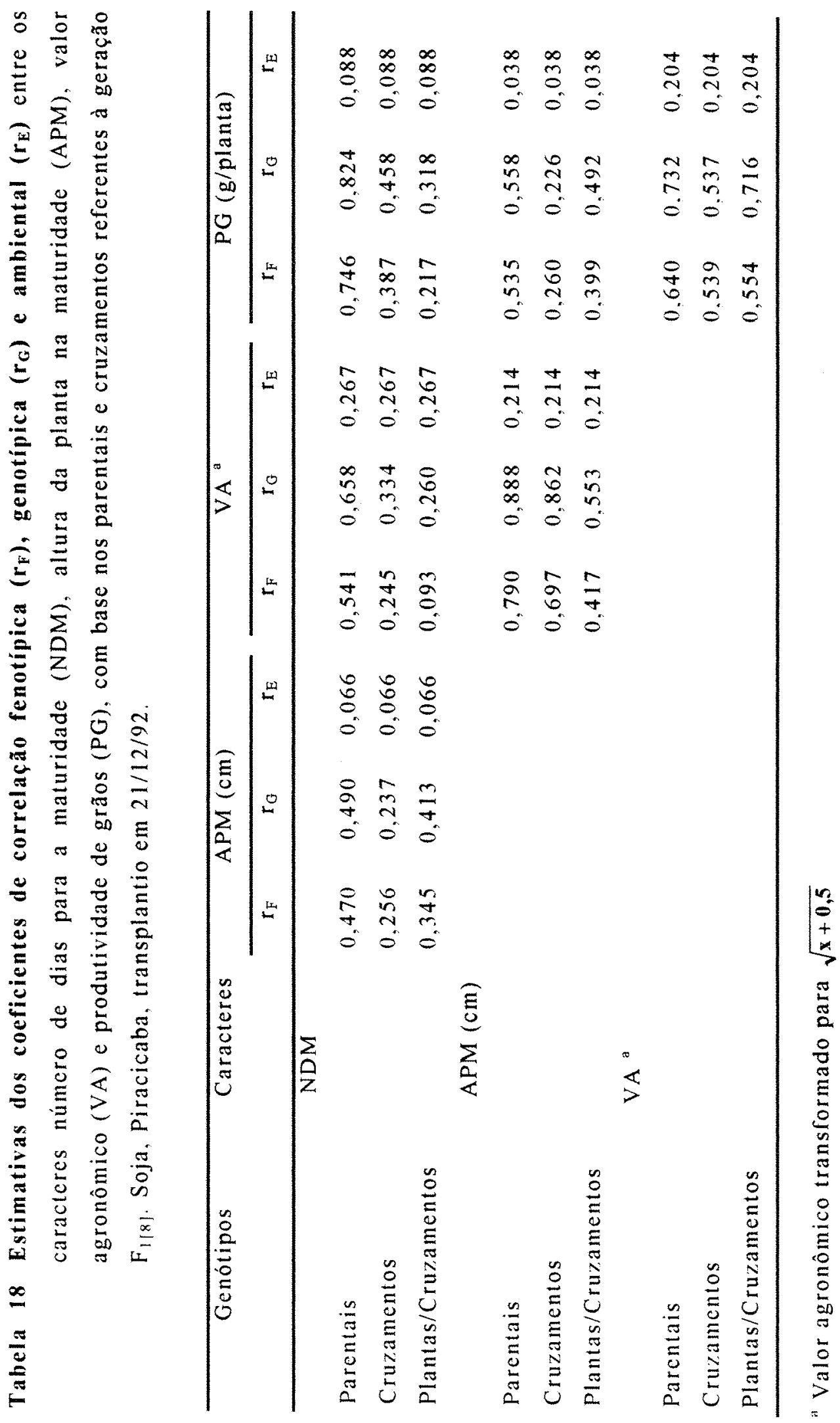




\section{FIGURAS}



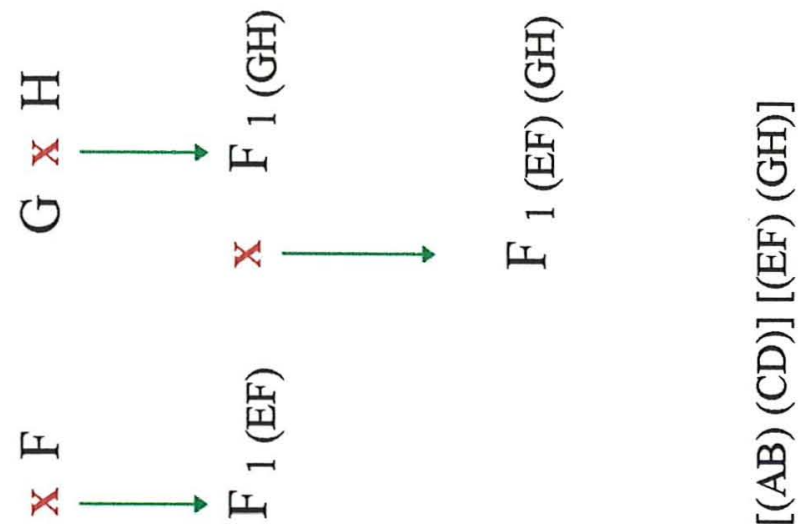

[I]
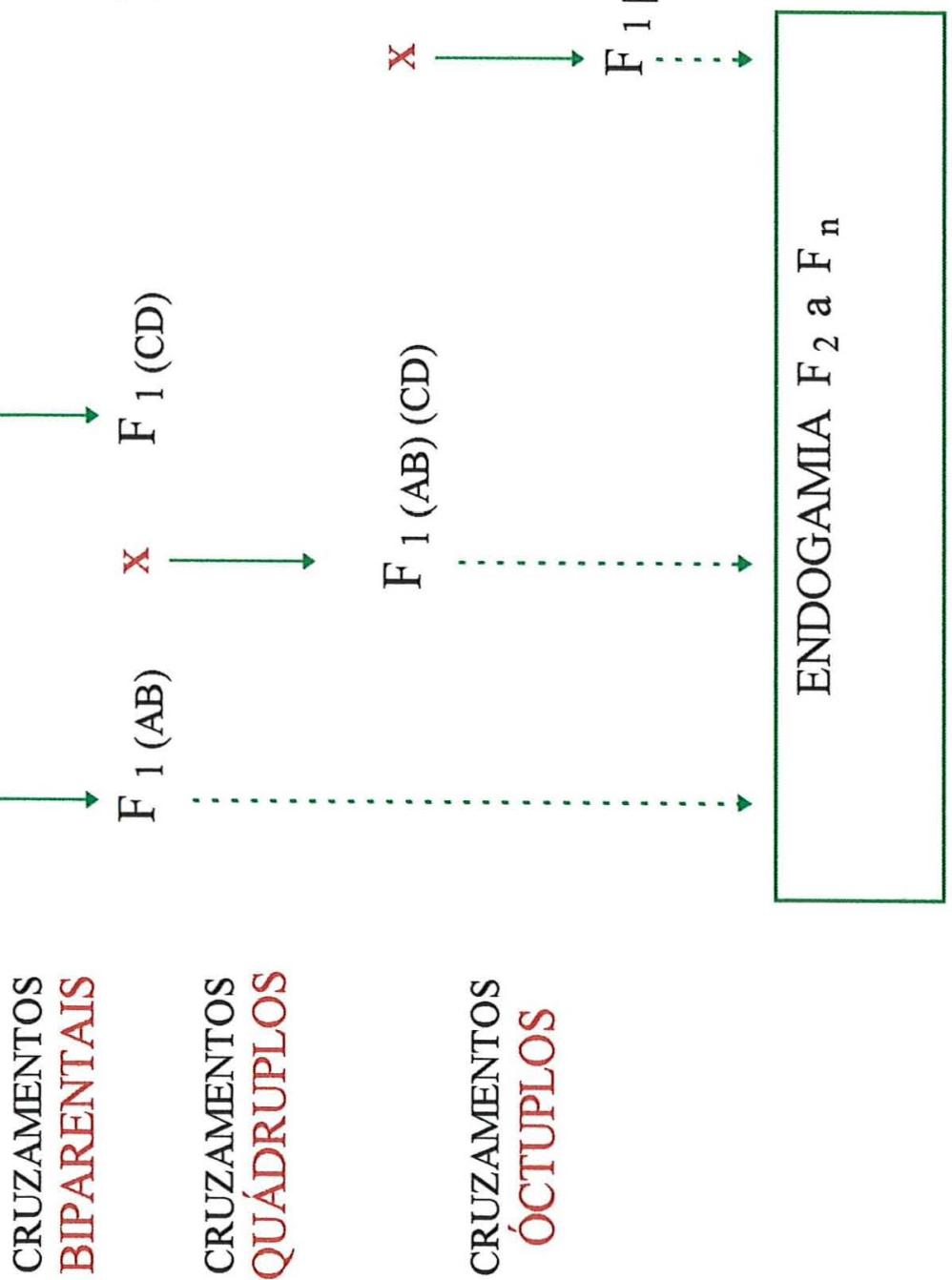

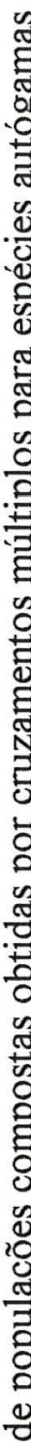
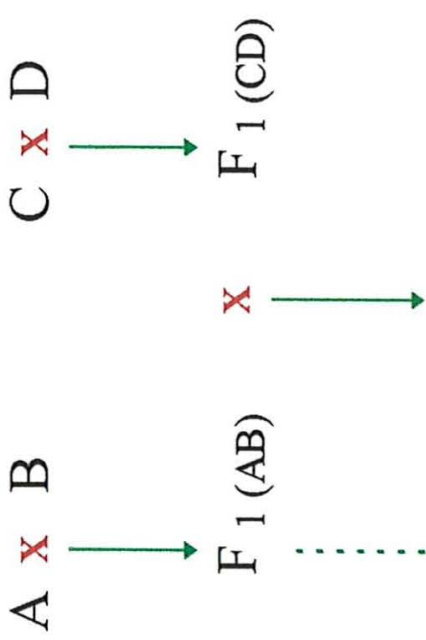

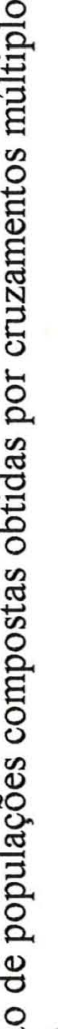

苂

范

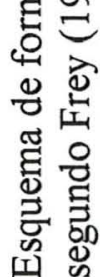

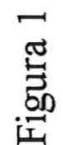




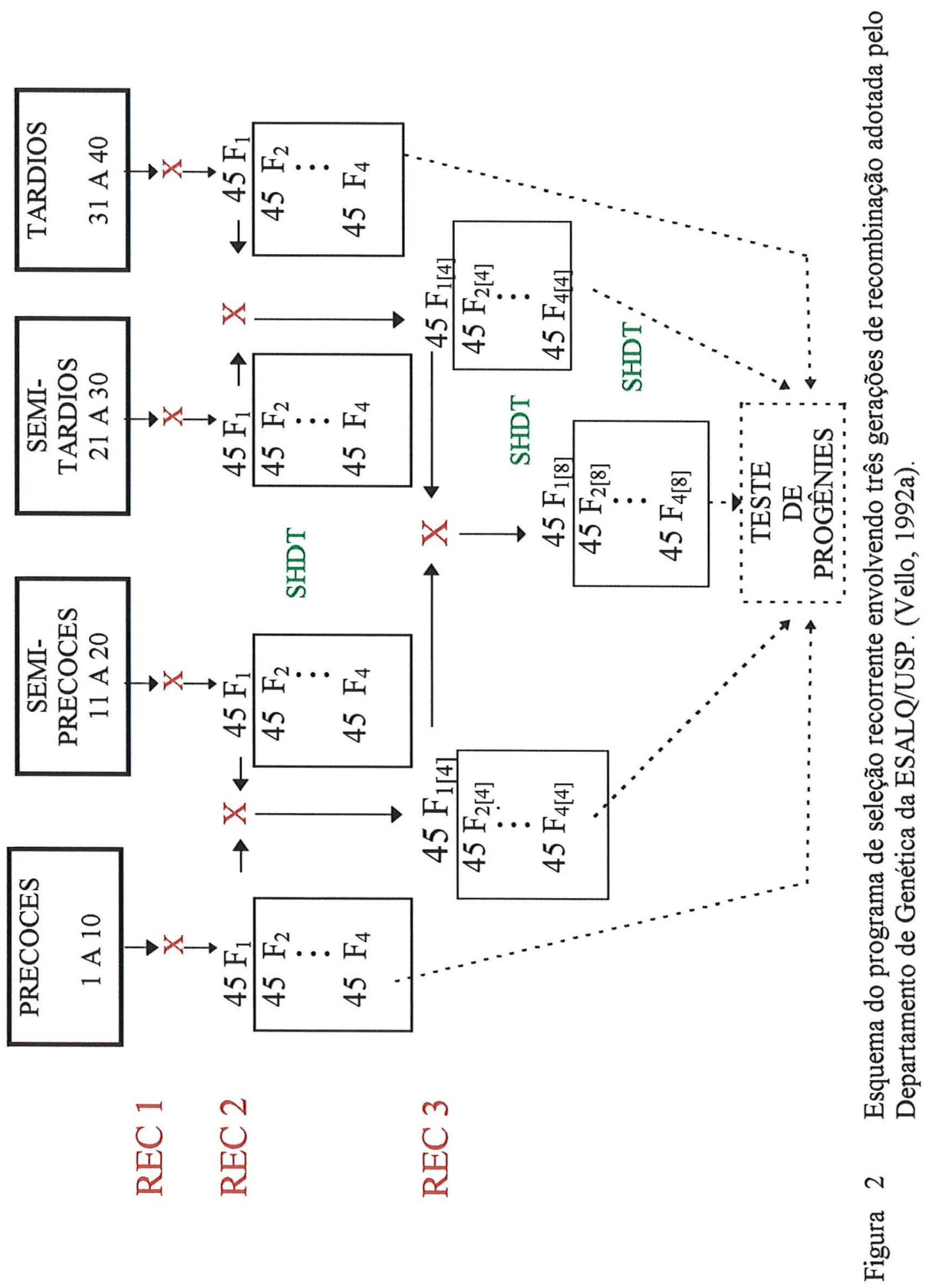


APÊNDICES 
Apêndice 1 Relação dos 40 parentais utilizados nos 60 cruzamentos óctuplos em Soja e reação a alguns patógenos.

\begin{tabular}{|c|c|}
\hline GRUPO PRECOCE & GRUPO SEMI-PRECOCE \\
\hline No. gen./Genótipo & No. gen./Genótipo \\
\hline P01 CEPS-7716 & P11 Bossier \\
\hline P02 Coker 136 & P12 BR-1-Fosca $(\mathrm{R}=1)$ \\
\hline P03 Forrest $(\mathrm{R}=4)^{\mathrm{a}}$ & P13 Davis \\
\hline P04 FT 81-1835 & P14 FT $81-2706$ \\
\hline P05 FT 81-2134 & P15 GO 81-11046 \\
\hline P06 Hale-321 & P16 IAC-1 \\
\hline P07 IAC-Foscarin $31(\mathrm{R}=1)$ & P17 IAC-10 \\
\hline P08 Paraná & $\mathrm{P} 18 \mathrm{IAC}-12(\mathrm{R}=1,2)$ \\
\hline P09 Primavera $(R=1)$ & P19 SOC $81-228$ \\
\hline $\mathrm{P} 10$ SOC $81-79(\mathrm{R}=4)$ & P20 Viçoja \\
\hline GRUPO SEMI-TARDIO & GRUPO TARDIO \\
\hline No. gen./Genótipo & No. gen./Genótipo \\
\hline P21 Cristalina $(\mathrm{R}=7,9,12 ; \mathrm{MR}=5)$ & P31 BR-11(Carajás) $(\mathrm{R}=12)$ \\
\hline P22 EMGOPA-301 $(\mathrm{R}=3,12 ; \mathrm{MR}=1,5,7)$ & P32 BR 79-63 \\
\hline $\mathrm{P} 23$ IAC-11 $(\mathrm{R}=6,8,9,12 ; \mathrm{MR}=5)$ & P33 GO 79-1039 \\
\hline P24 IAC-4 ( $R=8,11,12 ; M R=5,7,9,10)$ & P34 IAC-2 $(\mathrm{R}=1,9 ; \mathrm{MR}=5,7)$ \\
\hline $\mathrm{P} 25 \operatorname{IAC}-5(\mathrm{R}=12 ; \mathrm{MR}=5,7)$ & P35 IAC 80-3006 \\
\hline $\mathrm{P} 26 \mathrm{IAC}-6(\mathrm{R}=12 ; \mathrm{MR}=5)$ & P36 Numbaíra $(R=6,8,9,12 ; M R=1,5)$ \\
\hline P27 IAC-8 $(\mathrm{R}=2,12 ; \mathrm{MR}=5)$ & P37 Paranagoiana $(\mathrm{R}=12 ; \mathrm{MR}=5,10)$ \\
\hline P28 IAC-9 $(R=5,6,12)$ & P38 Timbira $(\mathrm{R}=1,5,12 ; \mathrm{MR}=7)$ \\
\hline P29 Santa Rosa $(R=1,5,12 ; M R=7)$ & P39 Tropical $(R=2,7,12 ; M R=10)$ \\
\hline P30 SS-1 $(\mathrm{R}=9 ; 12 ; \mathrm{MR}=5,10)$ & P40 White Biloxi \\
\hline
\end{tabular}

${ }^{\mathrm{a}}$ Reação a patógenos $(\mathrm{R}=$ Resistente; $\mathrm{MR}=$ Moderadamente Resistente):

1: Cancro da Haste (Diaporthe phaseolorum f.sp. meridionalis)

2: Nematóide de Galha (Meloidogvne incognita)

3: Nematóide de Galha (Meloidogvne javanica)

4: Nematóide de Cisto ( Heterodera glycine )

5: Mancha Púrpura (Cercospora kikuchi)

6: Vírus do Mosaico Comum da soja (Sovbean mosaic virus)

7: Míldio Pulvurulento ( Peronospora manshurica)

8: Crestamento Bacteriano ( Pseudomonas syringae pv. glycinea)

9: Mancha Olho-de-rã ( Cercospora sojina)

10: Mancha Parda (Septoria glycines)

11: Fusarium (Fusarium oxysporum)

12: Pústula (Xanthomonas campestris pv. phaseoli) 


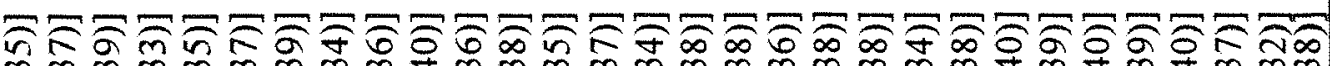

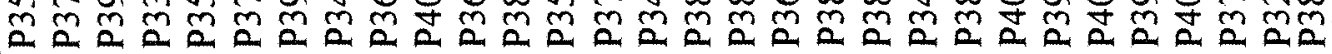

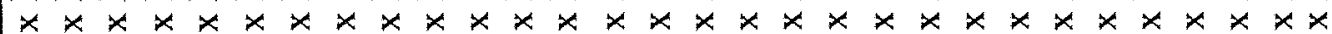
프류제

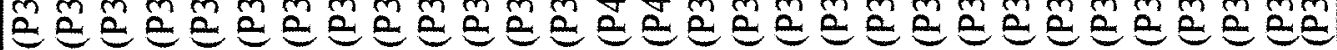
$x \times x \times x \times x \times x \times x \times x \times x \times x \times x \times x \times x \times x \times x \times x \times x$

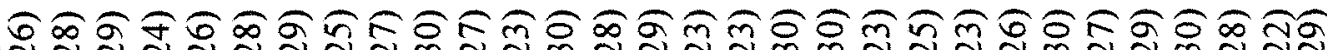

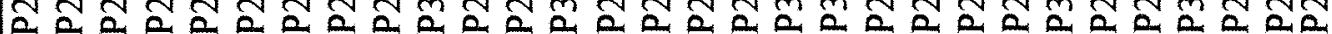
$\times \times \times \times \times \times \times \times \times \times \times \times \times \times \times \times \times \times \times \times \times \times \times \times \times \times \times \times \times x$ テ̄̄

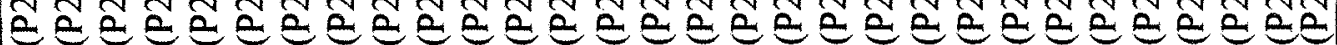
$x_{x} x_{x} x_{x} x_{x} x_{x} x_{x} x_{x} x_{x} x_{x} x_{x} x_{x}$

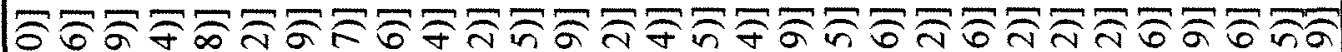

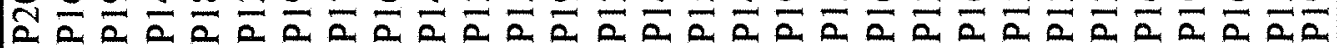
$\times \times \times \times \times \times \times \times \times \times \times \times \times \times \times \times \times \times \times \times x \times \times \times x \times x \times x \times$

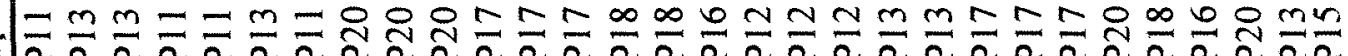

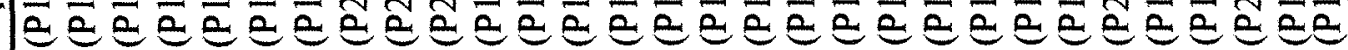
$\times x \times \times x \times x \times x \times x \times x \times x \times x \times x \times x \times x \times x \times x \times x \times$

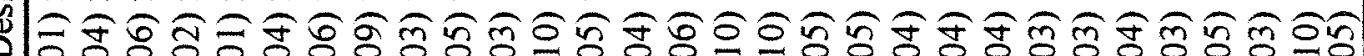

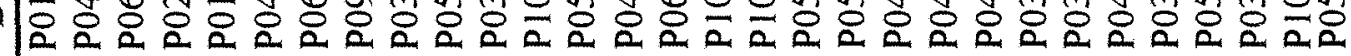
$\times \times \times \times \times \times \times \times \times \times \times \times \times \times \times \times \times \times \times \times \times \times \times \times \times \times \times x \times x$

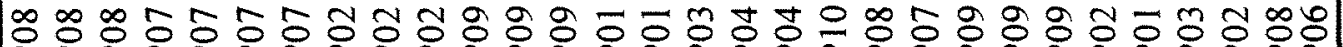

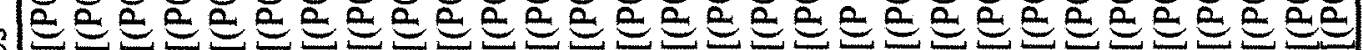

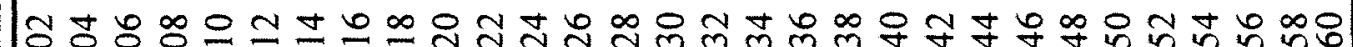
蛋

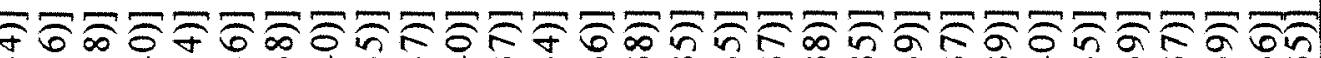

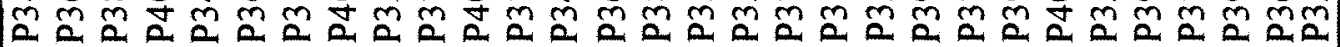
$\times \times \times \times \times \times \times \times \times \times \times \times \times \times \times \times \times \times \times \times \times \times \times \times \times \times \times \times \times \times$

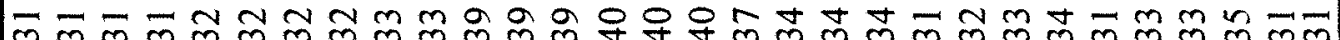

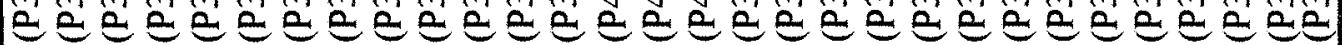
$x \times x \times x \times x \times x \times x \times x \times x \times x \times x \times x \times x \times x \times x \times x \times$

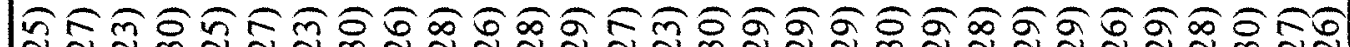

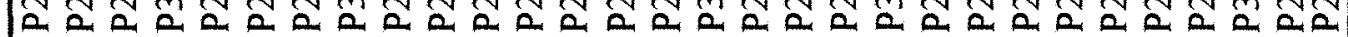
$\times \times \times \times \times \times \times \times \times \times \times \times \times \times \times \times \times \times \times \times \times \times \times \times \times \times \times \times \times \times$

デ̄̄ন

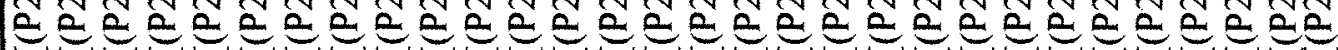
$x_{x} \times x_{x} x_{x} x_{x} x_{x} x_{x} x_{x} x_{x} x_{x} x_{x} x_{x} \times$

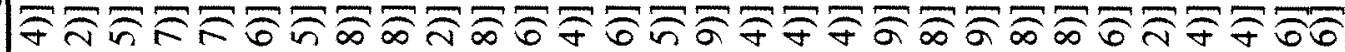

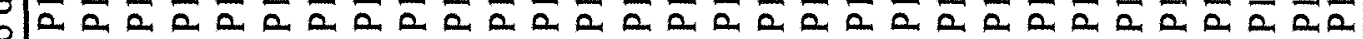
$\times \times \times \times \times \times \times \times \times \times \times \times \times \times \times \times \times \times \times \times \times \times \times x \times x \times x$

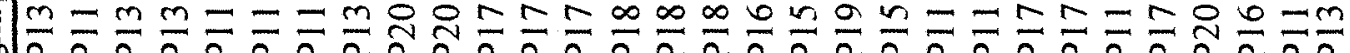

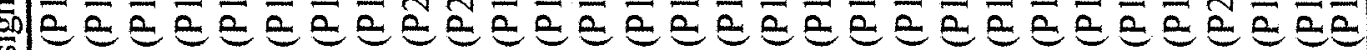

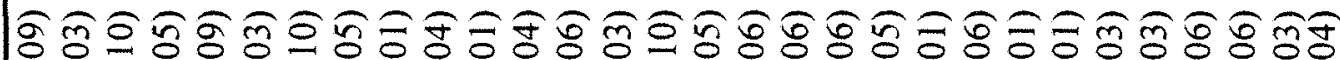

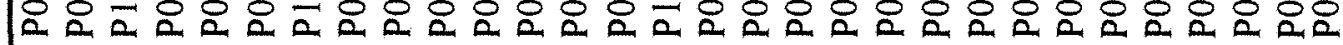
$\times \times \times \times \times \times \times \times \times \times \times \times \times \times \times \times \times \times \times \times \times \times \times \times \times \times \times \times \times x$

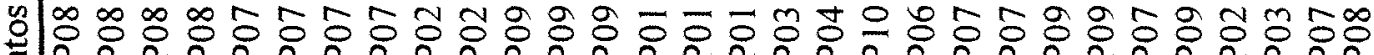

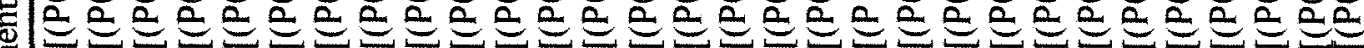


Apêndice 3 Estimativas das variâncias para o cálculo das correlações fenotípicas, genotípicas e ambientais, para parentais, cruzamentos e plantas dentro de cruzamentos referentes à geração $\mathrm{F}_{1[8]}$.

\begin{tabular}{|c|c|c|}
\hline Componentes * & simbologia * & estimativa \\
\hline variância genética de parentais & $\hat{\phi}_{\mathbf{p}}^{2}$ & $\frac{\mathrm{QM}_{6}-\mathrm{QM}_{1}}{\mathrm{k}_{3}}$ \\
\hline variância fenotípica de parentais & $\hat{\phi}_{\mathbf{F}}^{2}$ & $\frac{\mathrm{QM}_{6}}{\mathrm{k}_{3}}$ \\
\hline variância genética de cruzamentos & $\hat{\sigma}_{\mathbf{c}}^{2}$ & $\frac{\mathrm{QM}_{5}-\mathrm{QM}_{2}}{\mathrm{k}_{2}}$ \\
\hline variância fenotípica de cruzamentos & $\hat{\sigma}_{\mathbf{F}}^{2}$ & $\frac{\mathrm{QM}_{5}}{\mathbf{k}_{2}}$ \\
\hline $\begin{array}{l}\text { variância genética de plantas dentro } \\
\text { de cruzamentos }\end{array}$ & $\hat{\sigma}_{1 / c}^{2}$ & $\mathrm{QM}_{2}-\mathrm{QM}_{1}$ \\
\hline $\begin{array}{l}\text { variância fenotipica de plantas dentro } \\
\text { de cruzamentos }\end{array}$ & $\hat{\sigma}^{2} \mathbf{F}_{1 / c}$ & $\mathbf{Q M}_{2}$ \\
\hline variância ambiental & $\hat{\sigma}_{\mathbf{e}}^{2}$ & $\mathbf{Q M}_{1}$ \\
\hline
\end{tabular}

* Tabelas 1,2 e 3 . 
Apêndice 4 Estimativas das covariâncias para o cálculo das correlações fenotípicas, genotípicas e ambientais, para parentais, cruzamentos e plantas dentro de cruzamentos referentes à geração $\mathrm{F}_{1[8]}$.

\begin{tabular}{|c|c|c|}
\hline Componentes * & simbologia * & estimativa \\
\hline $\begin{array}{l}\text { covariância genética de parentais } \\
\text { entre os caracteres } X \text { e } Y\end{array}$ & $\operatorname{Cov}_{p}(X, Y)$ & $\frac{\mathrm{PM}_{6}(\mathrm{X}, \mathrm{Y})-\mathrm{PM}_{1}(\mathrm{X}, \mathrm{Y})}{\mathrm{k}_{3}}$ \\
\hline $\begin{array}{l}\text { covariância fenotípica de parentais } \\
\text { entre os caracteres } X \text { e } Y\end{array}$ & $\operatorname{CoV}_{F_{p}}(X, Y)$ & $\frac{\mathrm{PM}_{6}(\mathrm{X}, \mathrm{Y})}{\mathrm{k}_{3}}$ \\
\hline $\begin{array}{l}\text { covariância genética de cruzamentos } \\
\text { entre os caracteres } \mathbf{X} \text { e } \mathbf{Y}\end{array}$ & $\operatorname{CoV}_{c}(X, Y)$ & $\frac{\mathrm{PM}_{5}(\mathrm{X}, \mathrm{Y})-\mathrm{PM}_{2}(\mathrm{X}, \mathrm{Y})}{\mathrm{k}_{2}}$ \\
\hline $\begin{array}{l}\text { covariância fenotípica de cruzamentos } \\
\text { entre os caracteres } X \text { e } Y\end{array}$ & $\operatorname{CoV}_{F_{c}}(X, Y)$ & $\frac{\mathrm{PM}_{5}(\mathrm{X}, \mathrm{Y})}{\mathrm{k}_{2}}$ \\
\hline $\begin{array}{l}\text { covariância genética de plantas dentro de } \\
\text { cruzamentos entre os caracteres } X \text { e Y }\end{array}$ & $\operatorname{COV}_{1 / \mathrm{c}}(\mathrm{X}, \mathrm{Y})$ & $\mathrm{PM}_{2}(\mathrm{X}, \mathrm{Y})-\mathrm{PM}_{1}(\mathrm{X}, \mathrm{Y})$ \\
\hline $\begin{array}{l}\text { covariância fenotipica de plantas dentro de } \\
\text { cruzamentos entre os caracteres } \mathbf{X} \text { e } \mathbf{Y}\end{array}$ & $\operatorname{COV}_{F_{1 / c}}(X, Y)$ & $\mathbf{P M}_{2}(\mathbf{X}, \mathbf{Y})$ \\
\hline $\begin{array}{l}\text { covariância ambiental entre os caracteres } \\
\qquad \mathbf{X ~ e ~ Y ~}\end{array}$ & $\operatorname{Cov}_{\mathrm{e}}(\mathrm{X}, \mathrm{Y})$ & $\mathbf{P M}_{1}(\mathbf{X}, \mathbf{Y})$ \\
\hline
\end{tabular}

* Tabelas 1,2 e 3. 